
Digitized by the Internet Archive in 2010 with funding from Boston Public Library 
Please do not destroy or throw away this publication. If you have no further use for it write to the Geological Survey at Washington and ask for a frank to return it

DEPARTMENT OF THE INTERIOR

HUBERT WORK, Secretary

United States Geological Survey George OtIS SMith, Director

Bulletin 760-B

\title{
THE PHYSICAL FEATURES OF CENTRAL MASSACHUSETTS
}

\author{
BY \\ WILLIAM C. ALDEN
}

Contributions to the geography of the United States, 1923-24

(Pages 13-105)

Published December 16, 1924

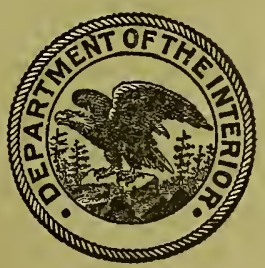

W A SHINGTON

GOVERNMENT PRINTING OFFIOE

1924 



\title{
DEPARTMENT OF 'LHE INTERIOR \\ HUBERT WORK, Secretary \\ United States Geological SuRvey George Otis Smith, Director
}

\section{Bulletin 760-B}

\section{THE PHYSICAL FEATURES OF CENTRAL MASSACHUSETTS}

\author{
BY \\ WILLIAM C. ALDEN
}

Contributions to the geography of the United States, 1923-24

(Pages 13-105)

Published December 16, 1924

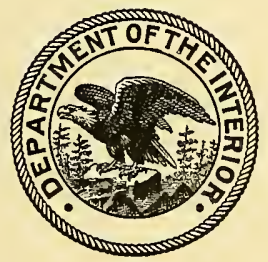

W A SHINGTON

GOVERNMENT PRINTING OFFIOE

1924 
i

U. S. SUPERIATENDENT OF DOCUMENTS

भi 20,1925 


\section{CONTENTS.}

Introduction _. . .

Origin and history of the central Massachusetts upland

The Cretaceous peneplain

Early Tertiary streams and valleys.

Later Tertiary stream adjustments..._. 23

Relations of the topography to the rock formations........ 27

Quaternary geology

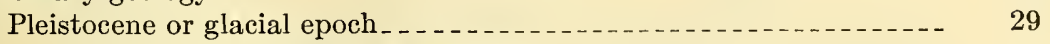

Phenomena indicative of glaciation

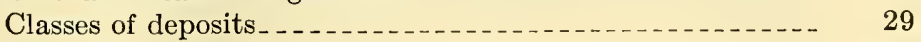

General character of the glacial drift $\ldots \ldots \ldots \ldots$

Glacial and interglacial stages...................... 32

Directions of the ice movement....... 34

Thickness of the ice

Pre-Wisconsin deposits _._.

Lacustrine clay _... 37

Residual material_._._. 38

Wisconsin drift. $\ldots \ldots \ldots$

The ground moraine

General character $\ldots \ldots \ldots$

Drumlins _................ 40

Terminal moraines

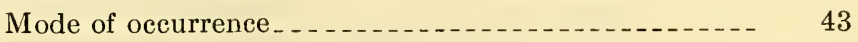

Terminal moraines of Quinsigamond quadrangle..... 45

Terminal moraines of Ware quadrangle _........... 46

Kame terraces.......... 47

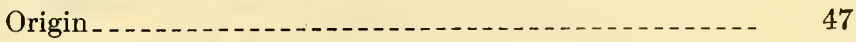

Kame terraces of Quinsigamond quadrangle__-_-_-_- 49

Kame terraces of Ware quadrangle._._._. 50

Eskers and glacial stream channels_................. 50

Eskers of Quinsigamond quadrangle_._._._.... 50

Eskers of Ware quadrangle............ 52

Origin of eskers

Glacial stream channel _.

Stream terraces_... 56

Location_........ 56

Origin

Boulders

Extinct glacial lakes....... 59

Changes in elevation of the land

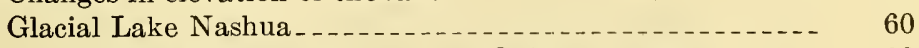

Deposits of the preliminary or Quinapoxet stage ..... 60

Deposits of the Boylston stage............... 61

Deposits of the Clinton stage

Deposits of the Ayer stage. 72 
Quaternary geology-Continued.

Pleistocene or glacial epoch-Continued.

Extinct glacial lakes-Continued.

Page.

74

Glacial Lake Assabet ...

Glacial lakes and streams of Ware quadrangle..........

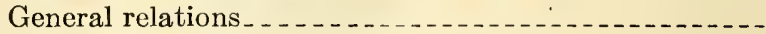

Glacial lake near Southbridge.......................

Glacial lakes of Brimfield and Warren ..............

Glacial Lake Brookfield. . . . . . . . . . . . . . . . . . . .

Glacial Lake Quaboag - -

Ware and Swift river drainage systems. . . . ..........

Glacial Lake Pelham and associated lakes and water-

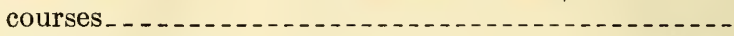

Marginal drainage of the Connecticut Valley glacial

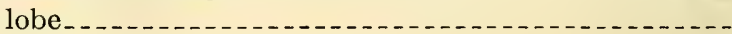

The Connecticut Valley lakes...

Summary of the Pleistocene or glacial history Recent epoch
75

\section{ILLUSTRATIONS.}

Plate VI. Map showing Quaternary geology of the Ware and Quinsiga-

Page. mond quadrangles, Mass ............................. In pocket.

VII. Diagram showing stages of retreat of the glacial margin in the Ware and Quinsigamond quadrangles, Mass ............ In pocket.

VIII. $A$, Dissected plateau of central Massachusetts; $B$, Wachusett Mountain, a monadnock rising above the plateau of central Massachusetts.................................

IX. $A$, Glacial till, a hill of unsorted glacial drift north of Clinton, Mass.; $B$, Dana diorite ("ribbon gneiss") 1 mile southeast of Gibbs Crossing, Ware, Mass ........................

X. $A$, End of Lower Blase Dale Glacier, Disco Island, Greenland; $B$, Glaciated rock surface near Lower Blase Dale Glacier, Disco Island, Greenland ....

XI. Glaciated rock ledge at Clinton, Mass

XII. $A$, Crumpled laminated clay, possibly interglacial; $B$, Esker

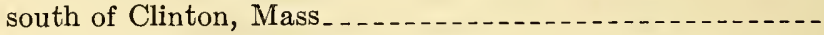

XIII. Map of Massachusetts showing distribution of drumlins - - - XIV. $A$, Prospect Hill, a drumlin near North Charlton, Mass.; $B$, Drumlin northeast of Gleasondale, Mass._._........

XV. Flood plain and stream terrace........

XVI. $A$, Walls of glacial boulders inclosing farm lands near Dana, Mass.; $B$, Glacial boulders near Princeton Center, Mass.-

XVII. A, Glacial boulder north of Gilbertville, Mass.; $B$, Perched boulders 3 miles northwest of Barre, Mass_..........

XVIII. Map illustrating the relations of the ice front to glacial Lake Nashua at the Clinton stage.............................

XIX. $A$, Kettle holes in sand and gravel south of Clinton, Mass.; $B$, Foreset and bottomset beds of sand plain 3 miles southwest

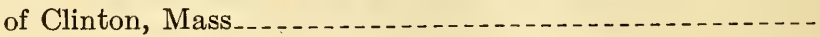

XX. $A$, Cross-bedded sand overlying laminated clay, Still River Station, Mass.; $B$, Laminated and crumpled lacustrine clay, Still River Station, Mass. 
Plate XXI. $A, B$, Potholes in bed of Blackstone River, Mass..........

XXII. $A$, Barre Falls, Mass.; $B$, Woolen mill, Gilbertville, Mass _ -

Figure 1. Map showing location of the Ware and Quinsigamond quadrangles, Mass

2. Map of central Massachusetts showing altitudes above sea level

3. Diagram illustrating stream changes in central Massachusetts_

4. Map of parts of New England, NewYork, and New Jersey, showing extent, directions of movement, and terminal moraines of the last great ice sheet

5. Map showing area covered by the great ice sheets in North America at their maximum extension and the centers of ice accumulation.

6. Diagram showing probable origin of many kettle holes......

7. Diagram illustrating formation of kame terraces

8. Diagram illustrating the relations of a branching sinuous gravel ridge, or esker, near Westboro, to drumlins, a stream valley, and a glacial terminal moraine

9. Diagram illustrating relations of the receding front of a melting glacial lobe and a later terminal moraine and outwash terrace to an earlier moraine and earlier terrace

10. Diagrams illustrating relations of the receding front of a glacial lobe in Nashua River valley to glacial Lake Nashua and the pitted terraces, or delta sand plains

11. Diagram illustrating relations of the ice front to glacial Lake Nashua near the end of the Boylston stage. 



\title{
THE PHYSICAL FEATURES OF CENTRAL MASSACHUSETTS.
}

\author{
By William C. Alden.
}

\section{INTRODUCTION.}

The area described in this paper lies mainly in central Massachusetts and comprises about two-thirds of the platean extending from the eastern part of the Connecticnt Valley on the west to the lowlands of Middlesex County on the east (fig. 1). The area is about

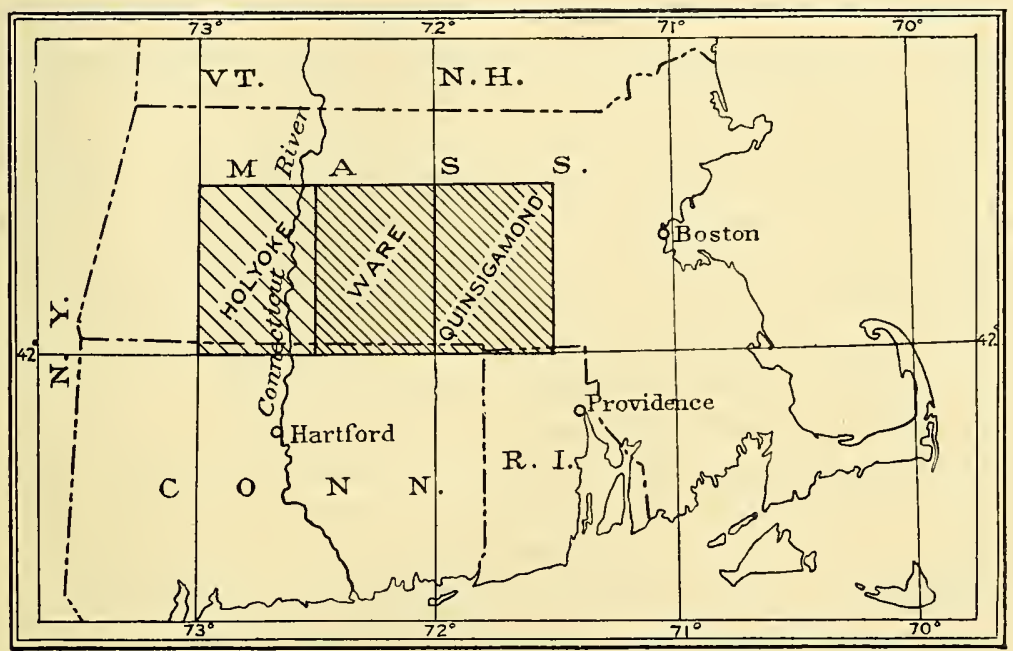

FIGURE 1.-Map showing location of the Holyoke, Ware, and Quinsigamond quadrangles, central Massachusetts.

52 miles in extent from east to west and 35 miles from north to south and includes approximately 1,835 square miles. It lies between parallels $42^{\circ} \mathrm{N}$. and $42^{\circ} 30^{\prime} \mathrm{N}$. and meridians $71^{\circ} 30^{\prime} \mathrm{W}$. and $72^{\circ}$ $30^{\prime} \mathrm{W}$. and thus includes on the south a strip of northern Rhode Island about half a mile to a mile wide and a strip of northeastern Connecticut about 2 to $2 \frac{1}{2}$ miles wide.

In the years 1885-1887 a topographic survey of the Belchertown, Barre, Worcester, Marlboro, Palmer, Brookfield, Webster, and Blackstone 15-minute quadrangles was made by the United States Geologi- 
cal Survey, and maps of these quadrangles were published on a scale of $1: 62,500$, or approximately 1 mile to the inch, with a 20 -foot contour interval. In 1908 these maps were combined into two covering the same area on a scale of $1: 125,000$, or approximately 2 miles to the inch, with a contour interval of 40 feet. The two 30 -minute quadrangles thus mapped were designated the Ware and Quinsigamond quadrangles. These maps are combined in the present paper (Pl. VI, in pocket) to show the physical features. ${ }^{1}$

The writer's examination of the surficial geology of this area was designed to be supplementary to the work of Prof. B. K. Emerson, who had for a long time been studying the deeper-seated hard-rock formations. The material included in the present paper was gathered in the summers of 1906 and 1907 and was originally prepared for publication with the results of Professor Emerson's studies in folios of the Geologic Atlas of the United States and was submitted, for examination and criticism, not only to Professor Emerson but to Profs. T. C. Chamberlin, W. O. Crosby, and J. H. Perry and later revised. To these gentlemen the writer wishes to express his appreciation for numerous suggestions. Professor Emerson had previously published the results of his own studies of the western part of this area and of the Holyoke quadrangle, which lies immediately west of the Ware quadrangle. ${ }^{2}$ To these publications and to personal conference with Professor Emerson the writer is much indebted. Considerable material has also been obtained from publications of other authors, as cited elsewhere in the text, particularly the "Physical geography of Worcester, Mass.," by J. H. Perry.

Professor Emerson's "Geology of Massachusetts and Rhode Island $" 3$ includes a brief description of the glacial and lacustrine phenomena of the Ware and Quinsigamond quadrangles and adjacent areas. Some material was prepared by the present writer during the World War for incorporation in a description of the country around Camp Devens, by W. W. Atwood, printed on the back of the Camp Devens topographic map, which covers parts of the Worcester, Marlboro, and adjacent quadrangles.

It is realized that publication so long after the time of the original studies, without reexamination of the field, incurs the risk of some anachronisms of description. It is hoped, however, that these will be found not to be serious. The elements of human history, such as

1 Such later features as the Wachusett Reservoir and changes due to its construction, enlarged towns, and the newer roads and electric railways are not shown on the 15-minute maps, but they show considerably more topographic detail than the Ware and Quinsigamond maps and are suitable for class and field use. All these maps are for sale by the Director of the United States Geologica: Survey, Washington, D. C., at 10 cents each, or 50 for $\$ 3$.

${ }^{2}$ Emerson, B. K., Geology of old Hampshire County, Mass. : U. S. Geol. Survey Mon. 29, 1898 ; U. S. Geol. Survey Geol. Atlas, Holyoke folio (No. 50), 1898.

${ }^{3}$ U. S. Geol. Survey Bull. $597,1917$. 
the settlement of the region by the whites and its commercial development, are not treated in this paper. For these subjects reference should be made to other sources, among which may be noted a pamphlet on the geography of Worcester, by Robert M. Brown, formerly of the State Normal School, who treats in an elementary form adapted to class use certain of the phenomena described in the present paper.

\section{ORIGIN AND HISTORY OF THE CENTRAL MASSACHUSETTS UPLAND.}

\section{THE CRETACEOUS PENEPLAIN.}

An observer standing on any portion of the upland of central Massachusetts that affords an extended view is struck at once with the remarkable uniformity of the horizon line (Pl. VIII, $A$ ). As he gazes in all directions and notes the general correspondence of upland and ridge crests, he is impressed with the idea that were the valleys filled up to the level of the summits of the ridges the whole would constitute a nearly uniform plain sloping gently toward the southeast and with but few elevations rising above it. The mineral composition and the attitude of the closely crumpled rock formations now exposed at the surface in this region (Pl. IX, $B$ ) are for the most part of the types that are generally associated with the internal structure of mountain folds and are developed only at great depths below the surface of the earth, and it is therefore evident that the exposure of these formations must be due to the removal of great thicknesses of overlying rock. In consequence New England has been called a "worn-down mountain region." " The removal of this material was accomplished principally by the ordinary processes of rock weathering or decay and stream erosion, such as are going on about us every day. The upland represents an ancient land surface developed through long-continued wearing down, which reduced most of the preexisting land forms to a plain gently sloping to the sea. Such a surface is called a peneplain-that is, almost a plain. Valleys were broadened and mountains, hills, and ridges were cut away until but few portions of the former elevated tracts remained. The most notable of the remnants of higher levels still persisting in the area under consideration are Wachusett Mountain (Pl. VIII, B), Little Wachusett, and Asnebumskit Hill. Farther northwest, in New Hampshire, stands Mount Monadnock, the typical representative of such topographic features, to which its name (monadnock) has been given. ${ }^{5}$ The wearing away of the ancient mountain ranges

\footnotetext{
4 Davis, W. M., The physical geography of southern New England, in The Physiography of the United States: Nat. Geog. Soc. Mon., p. 280, 1896.

"Davis, W. M., The improvement of geographical teaching: Nat. Geog. Mag., vol. 5. p. $70,1893$.
} 
required an exceedingly long time-many thousands or millions of years. An account of the formation and destruction of these mountains of long ago is not attempted in the present paper, nor are the dim vistas of yet remoter ages penetrated. The description begins at the time when the mountains had gone and the peneplain had been developed.

The detritus from the long-continued erosion of the land was swept by the streams into the bordering seas, forming sedimentary strata. The fossils now found embedded in these strata are forms that lived in the Cretaceous period, and the ancient land surface is therefore known as the Cretaceous peneplain. To visualize this ancient peneplain it is necessary, as indicated above, to imagine the depressions filled up to the level of the intervening ridge crests, for the peneplain is now largely dissected by valleys ranging in depth from 100 to several hundred feet. Moreover, most of the valleys give evidence of having been partly refilled since they were cut. As such dissection of a worn-down land surface is accomplished only in consequence of uplift sufficient to give to the sluggish streams the renewed energy resulting from increased fall, it is concluded that the peneplain has been raised to its present position since its derelopment. As shown in Figure 2, most of the higher portions of this peneplain are in the north-central part of the area, northeast of Worcester and north of the main line of the Boston \& Albany Railroad. Here great tracts stand from 900 to 1,300 feet above sea level. Smaller tracts at nearly the same general altitude extend the high belt southward from Warren into the eastern part of Hampden County and Connecticut. From this axial zone the general upland slopes from 900 to 500 feet above sea level in a southeasterly direction toward Rhode Island, and to about 400 to 600 feet in an easterly direction, to the borders of the lower Nashua, Assabet, and Blackstone river basins in eastern Worcester County. The high portions (900 to 1,300 feet above sea level) are also extensively preserved north of Belchertown and west of Middle Branch of Swift River. Prior to the uplift in late Cretaceous time the peneplain was probably continuous throughout this region and extended westward across what it now the Connecticut Valley lowland.

It has been pointed out by Barrell ${ }^{6}$ that the surface descends from the higher altitudes in southern New England toward the coast not by a simple regular slope but by a series of steps. Barrell has suggested that after dissection of the region had reached an advanced stage the land was lowered, in part below sea level, so that the interstream ridges became peninsulas, islands, and reefs, which were then in turn partly worn away by marine wave action. Repeated wave

${ }^{6}$ Barrell, Joseph, The piedmont terraces of the northern Appalachians (edited by IH. II. Lobinson): Am. Jour. Sci., 4th ser., vol. 49, pp. 227 et seq., 1920. 


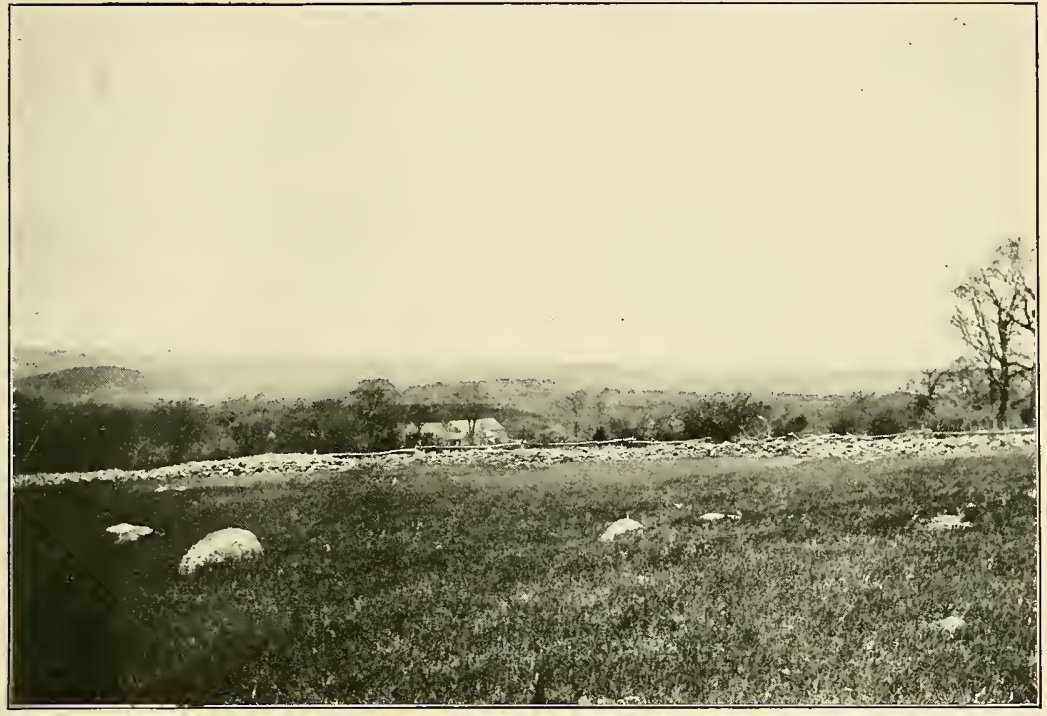

A. Dissected Plateau of Central massachusetts.

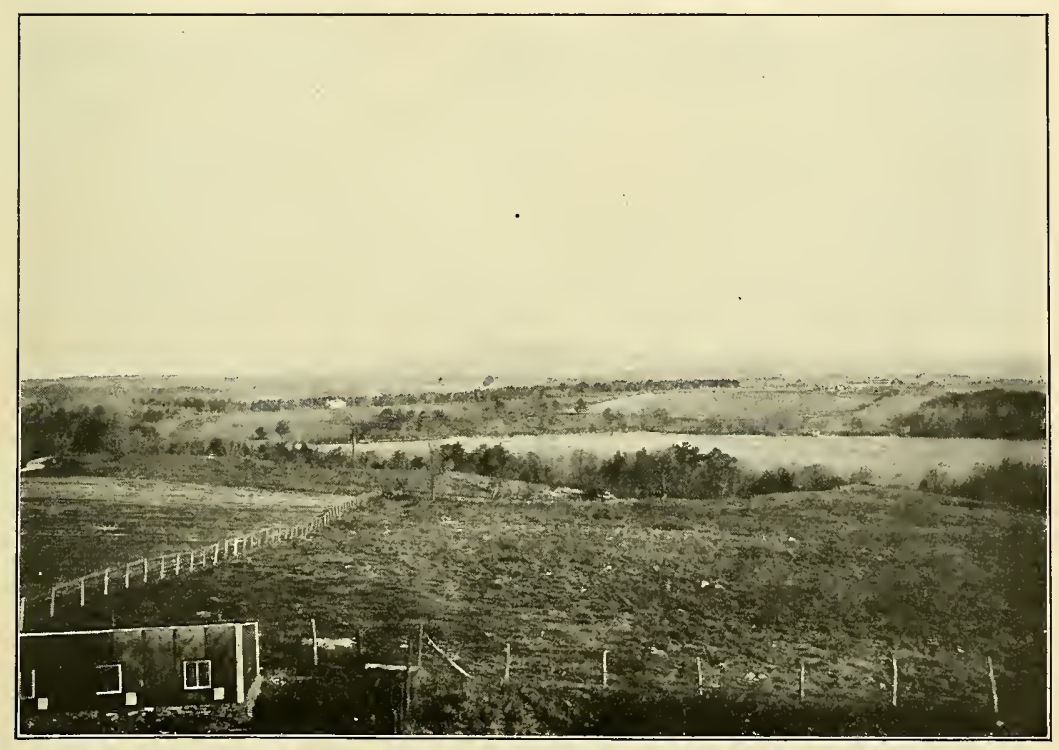

B. WaChusett moUntain, A MONADNOCK RISING above THE PlateaU OF CENTRAL MASSACHUSETTS. 


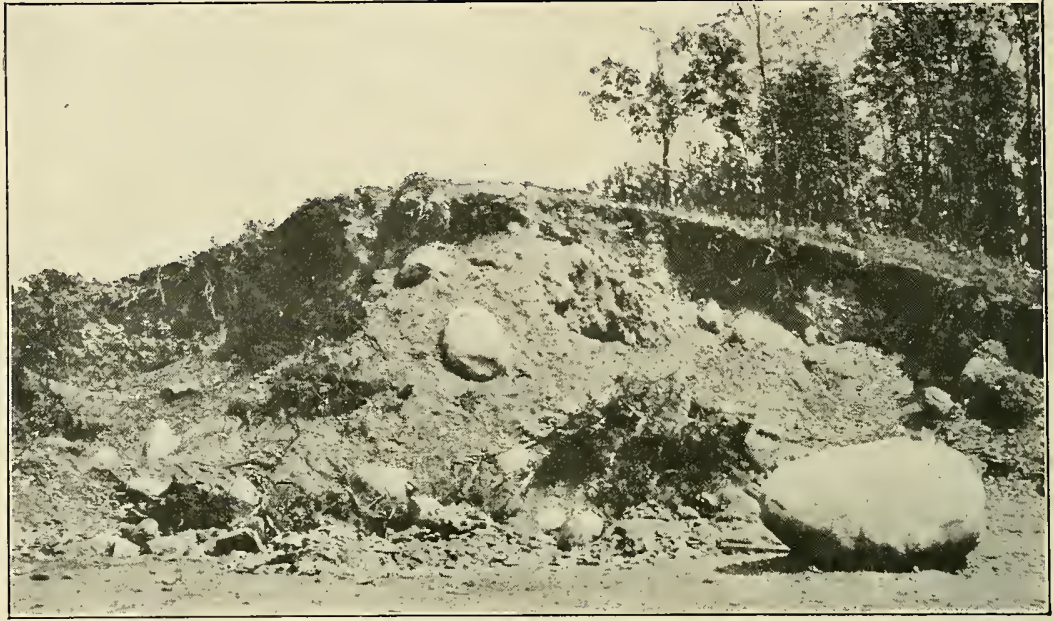

A. GLACIAL TILL, A HILL OF UNSORTED GLACIAL DRIFT NORTH OF CLINTON, MASS.

Photograph by W. W. Atwood.

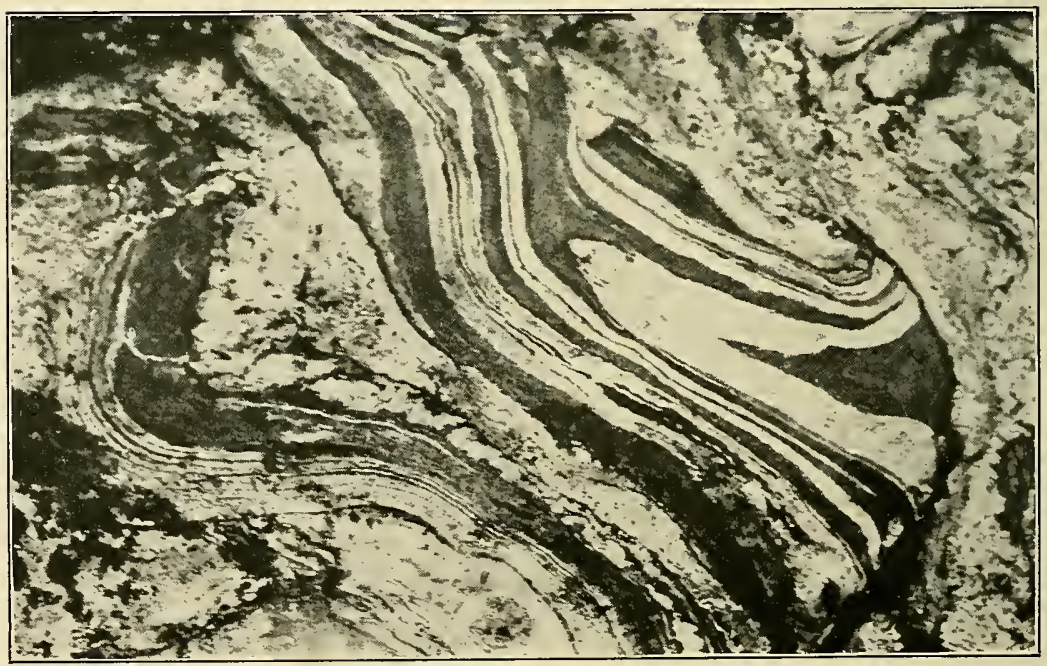

B. DANA DIORITE ("RIBBON GNEISS") 1 MILE SOUTHEAST OF GIBBS CROSSING, WARE, MASS. 
cutting following each of several successive uplifts of the region resulted in the development of a series of great steps or dissected

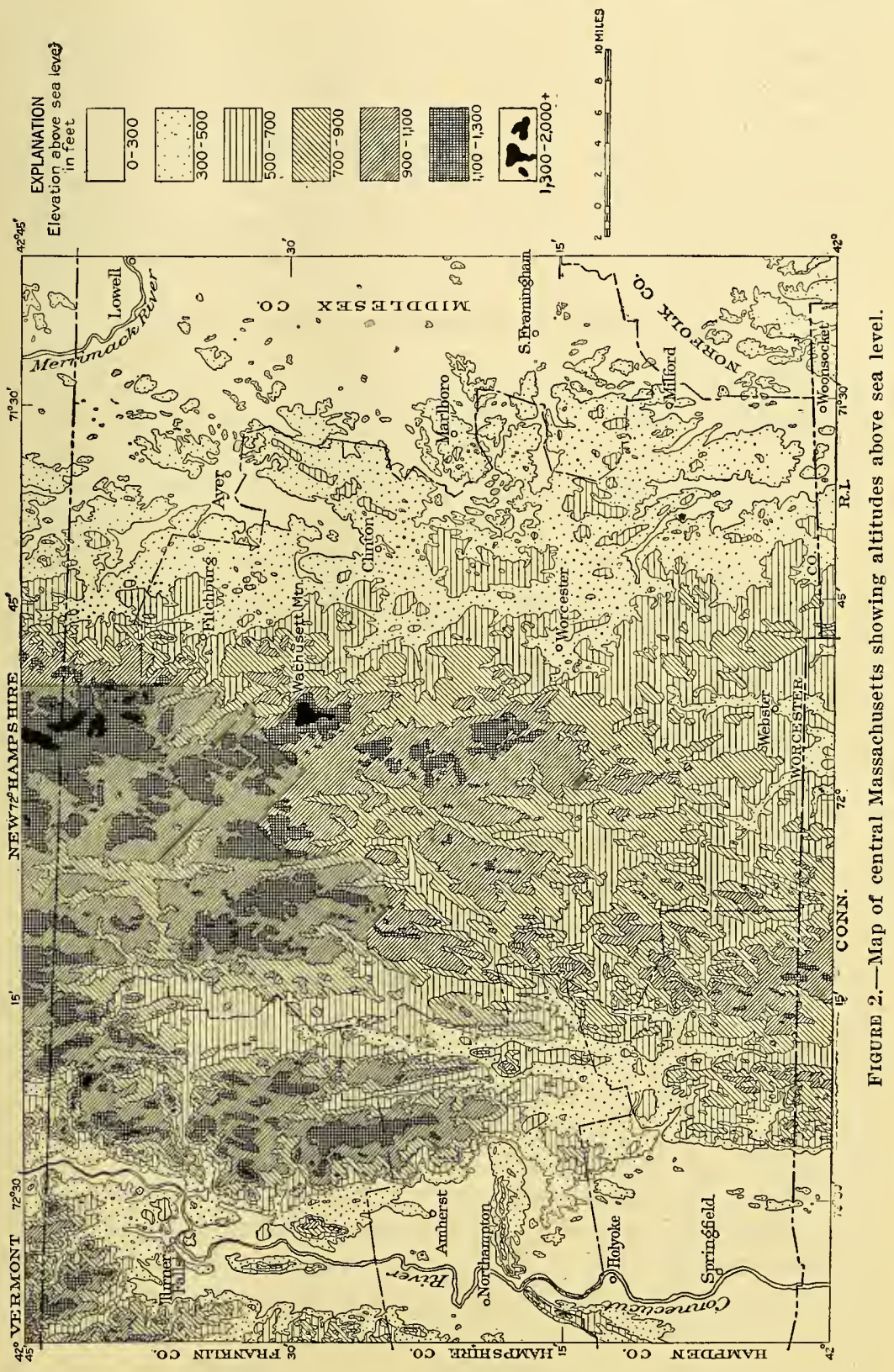

terraces dropping from the highest levels toward the coast line on the south and east of New England. These steps are said to be recognizable in broad cross-country views at the different altitudes. 
One of them is supposed to embrace the higher parts of the area under consideration and appears to correspond to what has been described above as the Cretaceous peneplain. The drop to the next lower step is in general to be found along a zone extending from north to south a few miles east of Wachusett Mountain and Asnebumskit Hill, curving to the west near the latitude of Worcester, turning again southward in the region of Brookfield, and extending thence through or near eastern Hampden County into Connecticut. Barrell's hypothesis may be open to question but is outside the general scope of this paper and will not be further discussed here.

\section{EARLY TERTIARY STREAMS AND VALLEYS.}

In the next succeeding geologic period-the Tertiary-several streams either crossed or headed in this area, and it also appears that marked changes in the drainage system of the area occurred during Tertiary time. The changes were a consequence of differential erosion-that is, the more rapid wearing away of the softer than the harder parts of the rock formations that underlay the Cretaceous peneplain. This is shown by the fact that some streams follow courses that are otherwise unexplainable-that is, they flow in directions transverse to the general slope of the country rather than directly down the slope. It is shown also by the existence of capacious valleys which were clearly not excavated by the streams that now occupy them and by the occurrence of deep notches or wind gaps (cols) cut in the rock divides and not now occupied by streams. It is not possible to interpret the development of all such features of the landscape, and only some of the more significant. and most readily explained will be discussed here.

Crosby's studies of the region led him to believe that a plain formed by a mantle of Cretaceous sediments originally extended at least as far inland as the line of the Nashua Valley, and that after this plain of deposition was uplifted with the eroded peneplain, early in Tertiary time, the rivers found their way seaward across it in channels that bore no relation to the structure or composition of the older rocks beneath, and on the removal of the Cretaceous sediments by erosion the streams continued to flow in these channels, which were thus superimposed upon that part of the eroded peneplain that had been buried-that is, the stream courses then extended indiscriminately across belts of hard and soft rock alike. The original extent of the Cretaceous sediments is not fully known, but there can be little doubt that the development of the Tertiary drainage lines, whether on the uplifted plain of deposition or directly on the older worn-down plain, depended wholly on the slope and configuration of the newly elevated surface, regardless of the structure and vary- 
ing degrees of hardness of the rock formations beneath, and that the branching of the streams was much nearer the dendritic or treelike type than it is now.

Normally streams that have begun to cut on bedrock wear away soft rocks more readily than harder rocks, so that no matter where they begin to flow they have a tendency to readjust their courses and eventually, if nothing prevents, to follow more or less closely the belts of softer rocks. As a matter of fact, however, many different things generally happen to prevent perfect readjustment. During the process of readjustment in this area there were probably many changes in the courses of the streams. Several of the wind gaps in the rock ridges are regarded as portions of the courses of the earlier Tertiary streams that were later abandoned. The supposed courses of the early Tertiary drainage lines of the region about Worcester and adjacent areas are shown in Figure 3. Those forming parts of the ancestral Nashua River system were suggested by Crosby ${ }^{7}$ as a result of his studies in connection with the building of the dams for the Wachusett Reservoir.

The large gap in the east rim of the Nashua Valley near Ayer, 4 miles north of the village of Harvard (just north of the area shown on Pl. VI), was probably occupied by one of the main streams, which flowed thence northeastward along the line of Stony Brook valley to Merrimack River west of Lowell. The principal tributaries of this stream converging at the gap at Ayer were Nissitissit River, flowing southward in what is now Nashua Valley; Squannacook River, from the northwest; and possibly North Nashua River, flowing eastward from North Leominster past Shirley to Ayer, and a small stream flowing northward in what is now the main valley of Nashua River between Lancaster and Ayer.

There are three notches in the east rim of the valley in the vicinity of Clinton. (See fig. 3 and Pl. VI.) The most northerly is traversed by the New York, New Haven \& Hartford Railroad at Bolton Station, at an altitude of 384 feet above sea level; a second, 1 mile to the southwest, is occupied by that part of Clinton known as "The Acre," which has an altitude of 370 feet; and a third was formerly traversed by the Boston \& Maine Railroad from West Berlin to Boylston, about half a mile south of the Wachusett dam. This third gap, which is now blocked by the south dike of the Wachusett Reservoir, was an important outlet for glacial waters during Pleistocene time and may for convenience be designated the soutl-

${ }^{7}$ Crosby, W. O., Geology of the Wachusett dam and Wachusett aqueduct tunnel of the Metropolitan waterworks in the vicinity of Clinton, Mass.: Tech. Quart., vol. 12, pp. 68-96, 1899 ; Geological history of the Nashua Valley during the Tertiary and Quaternary periods : Idem, p. 2SS-334; Structure and composition of the delta plains formed during the Clinton stage in the glacial lake of the Nashua Valley: Idem, vol, 16, pp. 240-254, 1903 ; vol. 17 , pp. $37-75,1904$. 
dike outlet. Its altitude was about 360 feet. The first of these gaps is about 120 feet in depth, the second 70 to 80 feet, and the third 140

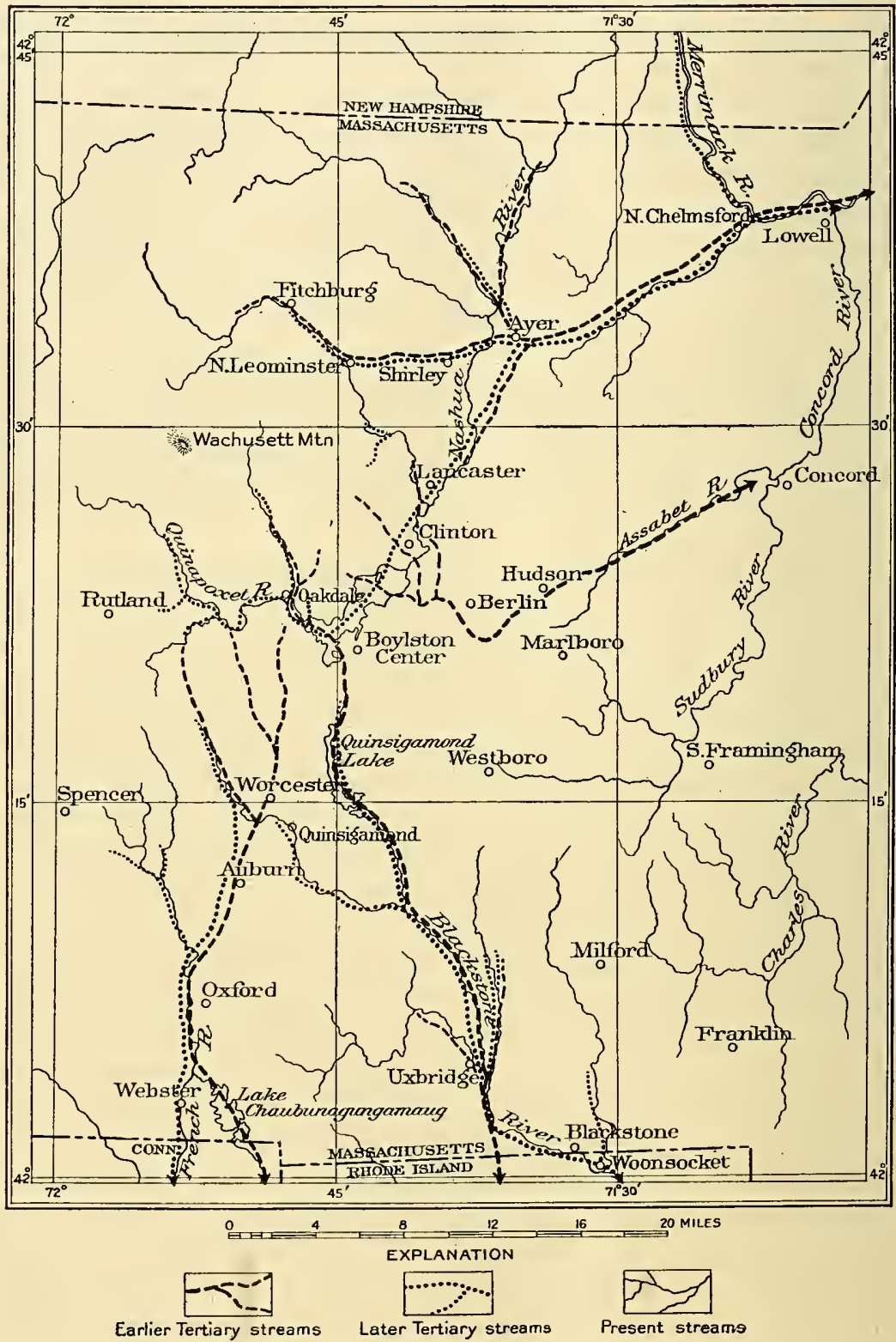

Figure 3.-Diagram illustrating stream changes in central Massachusetts. (Principally after W. O. Crosby and J. H. Perry.)

to 160 feet. These gaps are notable in that they do not occur at exceptionally weak points in the rock ridge but are cut in the most resistant rocks of the region-granite, diorite, and quartzite. From 
these gaps converging valleys now lead to the valley of North Brook, a tributary of the broad Assabet River basin, at West Berlin. In Tertiary time these passes were in all probability traversed by streams heading on the lower east slope of the Wachusett divide. It is believed that the broad Nashua Valley in the vicinity of Clinton was not then excavated, so that the streams converging to form this system may have been one on the line of the lower North Nashua River heading east of the north end of Ballard Hill and flowing thence through the gap at Bolton Station; one heading in the gap north of Redstone Hill and flowing thence through the sag in the ridge on which Clinton is built and through the gap directly opposite at "The Acre"; and a stream from the sag in which lie the Waushaccum Ponds, flowing through the south-dike outlet. Possibly at one stage Stillwater River may have followed this lastmentioned course. All these waters are thought to have reached the Atlantic Ocean at Boston Harbor by way of either the Merrimack or the Charles.

One mile southwest of Boylston Center the rim of Nashua Valley is cut by a gap over half a mile wide at the head of Quinsigamond Valley, the Muddy Brook gap. The lower parts of the rock bottom of this gap are probably not over 400 feet above sea level, and the crests on either side rise 200 to 300 feet higher. This gap is directly opposite the bend in the Nashua Valley, so that the eastern and western parts of the valley converge toward it. In continuation of the valley north of Oakdale is the valley of Stillwater River, and the normal course of that stream at an early stage would have been by way of Muddy Brook gap down Quinsigamond Valley, and a branch from Sterling Junction would have traversed the gap west of French Hill now filled with glacial drift.

The course of the main tributaries of Quinapoxet River from the south slope of Wachusett Mountain suggests an early channel through the gap 820 feet above sea level at the head of Tatnuck Brook and the gap 760 feet above sea level south of Chaffin Pond and thence to the ancient river valley at Worcester. Possibly also Stillwater River once went southward to the same valley by way of the gap north of Summit Station. If these inferences are correct these streams must have been diverted to the stream in Quinsigamond Valley through the process of capture, by which the liead of one stream cuts back into another stream's valley. As a rule, the pirate stream has a steeper grade or a greater volume or is working on softer rock and is cutting more rapidly than the stream whose waters it captures. That a considerable stream once flowed southward through Quinsigamond Valley is evident from the capacious dimensions of the valley, which is now largely blocked with drift and wholly out of proportion to the streamlets that occupy it. 
In the Blackstone Valley, farther south, the constricted rock channel from Millville to the eastern part of Blackstone is in striking contrast with the broad drift-filled sag south of Ironstone. This sag, which is a mile or more in width, leads southward directly in line with the broad valley of the Blackstone above the bend at Ironstone, and it might be inferred that the heavy filling of drift south of Ironstone diverted the river eastward. Further inspection, however, shows a series of rock ledges at close intervals across the valley near the head of the Ironstone Reservoir, at altitudes of 260 to 320 feet, and more or less drift filling occurs in the Blackstone Valley southeastward as far as Woonsocket. From these facts it appears that the Blackstone was diverted to its present course below Ironstone prior to the advent of the great ice sheet. Although the ancient valley has not been traced southward to the sea, it seems very probable that the original course of the stream in early Tertiary time was along the broad sag south of Ironstone. No well-marked terraces cut in rock occur in the Blackstone and Quinsigamond valleys, but at a few places there are evidences that a broadening of the rock bottom took place at altitudes corresponding with the gradient of an ancient valley floor from the gap at the head of Quinsigamond Valley southwest of Boylston Center to the sag south of Ironstone. These evidences are found in the exposures of bedrock beneath a slight covering of gravel of the Pleistocene terlaces. The most notable of these rock benches are in the angles between the converging Mumford, Blackstone, and West rivers, northeast of Uxbridge.

Another large Tertiary river was that which excavated the capacious valley leading southward from Worcester to Lake Chaubunagungamang, east of Webster. Northward from a divide 2 miles northeast of North Oxford the valley is now drained by Blackstone River through the narrow gap cut in the rock at Quinsigamond village. South of the divide, which is only an insignificant ridge of drift, the drainage goes to French River, which leaves the main valley at Webster for a much narrower channel. For more than 20 miles the broad valley bottom ranges in width from three-fourths of a mile to 2 miles, and the side slopes rise to heights of 200 to 400 feet above the present floor within distances of less than a mile. The filling of drift beneath the present bottom is reported to be in many places 60 to 90 feet thick. The valley is continuous from north to south and is wholly out of proportion to the small streams that now occupy it. It was clearly at one time a large drainage channel, and Perry" has suggested the name "Auburn River" as a convenient designation of the Tertiary stream that accomplished its excavation.

8 Perry, J. H., The physical geography of Worcester, Mass., p. 35, Worcester Nat. Hist. Soc., 1898. 
It is possible that at an early stage this stream received the drainage from the south slopes of Wachusett Mountain through cols north and northwest of Worcester by the streams that are now tributary to the Quinapoxet. Like Blackstone and Nashua rivers, the ancient "Auburn River" was apparently diverted in Tertiary time, before the excavation of the valley was fully accomplished. This is shown by the fact that near the railroad west of East Thompson, Conn., $1 \frac{3}{4}$ miles south of Lake Chaubunagungamaug, rock crops out at short intervals across the valley floor at latitudes of 480 to 560 feet above the sea, and as far north as Worcester, a distance of 19 miles, the rock bottom of the ancient valley has been encountered in drilling at altitudes as low as 370 to 400 feet.

Even though allowance is made for the possible changes in the relative altitudes of the several parts of the region, it seems clear that notable stream adjustments must have been accomplished prior to the advent of the Pleistocene glaciers. Similar changes deubtless occurred in the western part of the area, but they are not discussed in the present paper.

The preglacial course of Swift River is shown by Emerson ${ }^{9}$ to have led southward past Palmer and Monson along the valley traversed by the Central Vermont Railway and into Connecticut through the pass near Stateline Pond.

The reconstruction of the early Tertiary drainage systems above outlined is from the nature of the case entirely hypothetical, and it may not point out the exact changes that occurred in the process of stream adjustment; its value lies rather in showing the nature of the process by which the streams came to occupy their present channels. If the correctness of the interpretations is assumed, however, we have for early Tertiary time in that part of the then newly elevated peneplain which is under consideration an arrangement of streams such as is shown in Figure 2.

\section{LATER TERTIARY STREAM ADJUSTIMENTS.}

Nashua River occupies a deep and well-defined valley incised in the Cretaceous peneplain and carved out of argillaceous slate or phyllite between the great ridge of granitic and gneissic rocks on the west and a distinct ridge of granite and schist on the east. This phyllite was originally a bed of soft black coaly clay. It was compressed by the weight of overlying rocks and later squeezed and crumpled by mountain-making forces. This changed some of the minerals and caused the flakes of mica and graphite and other minerals to lie flat. The rock now stands on edge and splits very readily

${ }^{9}$ Emerson, B. K., U. S. Geol. Survey Mon. 29, pl. 11, 1898. $92817^{\circ}-24-2$ 
into thin layers, some of it yielding good roofing slate. Such being its character and position, it is easily worn away by running water. The stream, as shown by the map, does not follow a normal course dependent upon the slope of the ancient peneplain eastward to the sea but instead flows transverse to this general slope and parallel to the strike of the upturned rock formations north-northeastward to its confluence with the Merrimack at Nashua, N. H. Its course is in general adjusted to the geologic structure of the rock formations over which it flows.

The records of test borings to determine the location of the north dike of Wachusett Reservoir, as shown by Crosby, ${ }^{10}$ indicated that beneath the pitted sand plains which occupy the broad valley west and southwest of Clinton is a buried rock gorge, evidently an ancient channel of Nashua River. Crosby writes:

We find that the western slope of Burdette Hill, which is but thinly covered by till, extends for fully 1,000 feet beneath the plain of modified drift with the normal height of 380 feet, to a well-defined north-south depression with an average elevation of only about 200 feet, sloping both ways from a distinct water parting. A definite ridge of schist, which is covered at the highest point by 100 feet of modified drift, separates this depression from the deeper one beyond. Along the west side of the ridge $* * *$ is an uneven bedrock terrace several hundred feet wide, crossed by several spurs from the ridge and with an approximate elevation of 190 to 210 feet. Over this terrace, with 120 to 130 feet of drift intervening, lies Coachlace Pond; and immediately beyond and along a line parallel with the pond and the ridge the bedrock surface falls off abruptly about 100 feet more, and the drift reaches the astonishing thickness of 250 to nearly 300 feet.

The lowest elevation [above sea level] of the bedrock surface determined by the borings is 96.5 feet on the center line of the main cut-off, nearly 200 feet west of Coachlace Pond. Since it is improbable that this boring, which has a depth of 272.5 feet, is located over the very lowest point in this profile of the valley, and especially since it failed to reach bedrock, we may fairly assume that the minimum elevation of the bottom of the gorge on this line is at least as low as 95 feet, and probably as low as 90 feet.

That Nashua River in the narrow gorge at Clinton is ont of the course it followed prior to the deposition of the glacial drift is indicated by the topographic relations and by the fact that it flows over a granite ledge at the Chestnut Street Bridge, although at the site of the Wachusett Dam, half a mile farther upstream, borings show that the bottom of the narrow gorge lies 60 to 70 feet below the present bed of the stream. Crosby found that the buried gorge beneath the dam had been cut by a southward-flowing stream -along the contact of the westward-dipping granite and phyllite, with a precipitous and even overhanging wall of granite on the west. This gorge was doubtless tributary to the channel now buried beneath Coachlace Pond. 
The presence of the deeply buried channel west of Clinton, with its bottom less than 100 feet above sea level, at so great a distance from the sea-nearly 80 miles measured along the present courses of the Nashua and the Merrimack-naturally indicates a further extension of the ancient gorge, even though there are no borings in the Nashua Valley north of Clinton by which its location could be determined. Data obtained by Crosby from W. F. Sullivan, of the Lowell waterworks, showed that although the Merrimack at present flows over rock ledges at the lower dam at Lowell at an altitude of 92 feet above the sea and rock is exposed on either side of the channel or reached at shallow depths for some distance through the city below the dam, yet borings near the river above the dam show the presence of a buried channel with its bottom near sea level. Borings and other data indicated the probable continuation of the channel about either the north or the south side of the city of Lowell. Crosby's further studies convinced him that the preglacial course of the Merrimack below Lowell led southeastward to Boston Harbor.

Between 4 and 5 miles north of the village of Harvard, near Ayer, the rock ridge east of the Nashua Valley is breached by the gap already mentioned. This gap, which is at the point where the valley is widest, is about 1 mile in width. Beyond the gap the rock ridge extends northward, though it is not so high or continuous as it is south of the gap. Not only has the present lower Nashua River a retrograde course with reference to the Merrimack-that is, it flows in a general opposite direction-but the principal tributaries of the Nashua are also retrograde with reference to that stream, and, as pointed out by Crosby, there is a very decided convergence of the members of the Nashua River system toward this break in the eastern rim of the valley near Ayer. He states that this break is particularly notable, inasmuch as the present water parting between Nashua River and Stony Brook, which heads a short distance east of this break and enters the Merrimack at North Chelmsford, is almost imperceptible and apparently composed wholly of drift. Moreover, through the entire distance from its source east of Nashua River at Ayer to the Merrimack at North Chelmsford, Stony Brook traverses a broad and unobstructed valley entirely out of proportion to itself. Except at one place within a few rods of the mouth of the brook at North Chelmsford, Crosby found the valley virtually devoid of rock outcrops and apparently containing a considerable thickness of drift. "The valley," he writes, "is not only broad, but the breadth is remarkably uniform, so that it is practically a valley without a head, a mere strait some dozen miles in length between the Nashua and Merrimack valleys, and not at all the type of valley we should expect if it were due to the unaided activity of Stony Brook." His examination developed no facts inconsistent with the view that the 
Stony Brook valley, except for a short distance where obstructed by rock at North Chelmsford, afforded an outlet for the drainage of the Nashua Valley in preglacial time, and this view was further supported by the fact that the present valley of Nashua River north of Ayer is relatively narow and much obstructed by ledges. The reopening of the Stony Brook outlet for the Nashua River drainage would make the courses of all the principal tributaries direct-that is, they would all converge to the trunk stream in normal fashionwith the exception of the North Nashua, but this large branch would still have a retrograde course. Above North Leominster its course is essentially direct, but below that point for nearly 9 miles, to its confluence with the main stream at Lancaster, it is notably indirectthat is, it flows southeast to join the main stream, which is flowing northeast. At several places in the lower course the North Nashua flows over rock ledges. One of these is at the north end of Ballard Hill, and Crosby concluded that the earlier course was probably more directly eastward from North Leominster, past Shirley, to the outlet at Ayer.

If these interpretations are correct, the arrangement of the drainage lines of the Worcester region and adjacent areas immediately prior to the Pleistocene glaciation was not only somewhat different from the present arrangement, but even more notable readjustments had taken place earlier, during the Tertiary cycle of erosion. The changes in deployment of the streams shown in Figure 3 were probably accomplished through the process of stream capture (p. 21). The most notable captures were those made by Nashua River. The rate of cutting down the gap at Ayer through the granite ridge east of the valley controlled to a certain extent the work of the tributaries above the gap. The Tertiary course of this stream, its consequent steep fall, and the large drainage basin above this obstruction gave it considerable advantage over the other streams of the area, so that the gap at Ayer was deepened more rapidly than those at other points. West of the granite lies a broad belt of phyllite, one of the most easily erodible of the rock formations of the region. The character of this rock gave to those tributaries that were working along its strike-that is, parallel to its splitting planes-great advantage over all the others. Thus the headwaters of the small stream that was flowing northeastward from Lancaster cut back rapidly along the strike of the phyllite and diverted to itself, one after another, each of the streams that crossed this belt of phyllite. The first to be diverted was the stream which was engaged in cutting the gap at Bolton Station. This captive, if it had not already done so, in turn cut back and diverted the waters of Wekepeke. Brook and North Nashua River to their present courses. Next the streams cutting the gap at "The Acre" and the south-dike outlet fell victims to the ag- 
gressive Nashua. The divide which set off the river in Quinsigamond Valley was then attacked and speedily cut away, and at one stroke the whole Stillwater-Quinapoxet system was diverted to the Nashua. It is probable that by this time Stillwater River had captured the components of the Quinapoxet above Oakdale, even if they originally flowed through the cols north of Worcester. That part of the Nashua River system within the Quinsigamond quadrangle thus assumed approximately its present arrangement and continued the excavation of the capacious valley, whose full dimensions would be revealed were the filling of drift removed. In the vicinity of Clinton the Nashua excavated the buried channel described by Crosby, as shown by the borings for the north dike of Wachusett Reservoir. At the same time tributaries were cutting the gorge now traversed by the Nashua at Clinton, one working at the north and one at the south.

The Blackstone system was not only beheaded in the manner described, but the stream was also diverted from the broad valley south of Ironstone to the present narrow gorge through Blackstone by a tributary at Woonsocket. The main valley was still further deepened after this diversion, and the gap at Quinsigamond was cut down nearly to its present depth.

The ancient "Auburn River" was diverted from the broad valley in which lies Lake Chaubunagungamaug to the present course at Webster by French River, a tributary of the Quinebaug, and the valley was further deepened north of Webster. Similar changes on streams farther west doubtless occurred as Connecticut River deepened and broadened its valley in the Triassic sandstones. At the same time minor streams, brooks, and rivulets throughout the region were busily engaged in gullying slopes: and dissecting intervalley tracts and in removing the products of rock disintegration.

\section{RELATIONS OF THE TOPOGRAPHY TO THE ROCK FORIMATIONS.}

Emerson ${ }^{11}$ has given a brief summary of the relations of the present topograply to the rock formations, which contains the following paragraph:

At the completion of this [Cretaceous] epoch of erosion the surface of the State was a nearly continuous plain, sloping southward and eastward, of which the present broad, flat uplands are remnants. This plain was then raised as a whole, without folding but by broad warping and tilting, so that in the northwestern part of the State it stood about 2,000 feet above the sea. As a result of this uplift the streams, which ran southward and eastward across the plain, cut deep trenches in the upland. In the soft sandstones of the Connecticut Valley and the soluble limestones of the Housatonic Valley these trenches were widened into broad, flat-bottomed valleys, the beginnings of new,

${ }^{11}$ Emerson, B. K., Geology of Massachusetts and Rhode Island : U. S. Geol. Survey Bull. 597, pp. $15-17,1917$. 
transient peneplains, whose elevation was determined not oy sea level but by obstructions farther downstream. Thus erosion has marked out the broad topographic divisions of the State, which are also the broad geologic divisions.

Of the six topographic divisions which he recognizes the third, comprising the lowlands of the Connecticut Valley, mostly less than 300 feet above sea level, extends but a few miles into the area described in the present paper and ends at the west foot of the Wilbraham Mountains and the abrupt marginal slope of the upland farther north (fig. 2). The fourth and fifth divisions (in order from west to east) cover the greater part of this area. These divisions are described by Emerson as follows:

Third. The Devonian-Triassic valley of the Connecticut, in which there are sharp trap ranges topographically much like Monument Mountain, in the Housatonic Valley. Great faults along the scarps on both sides of the valley lave lowered and thus preserved the sandstones in which the valley has been cut to form a younger incipient peneplain.

Fourth. The central upland, or Worcester County plateau, made up of alternate broad bands of Carboniferous granite and narrower bands of folded schists, repeating in part the structure and lithology of the western upland. The northern part of the westernmost range of granite is rather resistant and forms monadnocks like Mount Grace, but its southern part has been deeply eroded in the Wilbraham Valley. The granite belt next east is made up of less resistant rock and forms the Monson Valley and the broad, relatively low strip that stretches from Orange to Palmer. The third granite belt is more resistant again and forms such monadnocks as Wachusett and Asnebumskit. Just east of it the weaker Worcester phyllite is worn down in the low Nashua Valley.

Fifth. The bordering slope that descends gradually eastward and southeastward from the irregular but fairly definite escarpment bounding the central upland. The descent is by no means uniform, and the general surface, if restored by filling the valleys to the height of the hilltops, would be not at all smooth and would not have a regular and gentle slope from the central upland to the coast. Southeastern Worcester County and northwestern Rhode Island are in large part upland of pre-Cambrian rocks, which, though much lower than the central upland, stands distinctly above the country northeast and southeast of it. Northeastern Massachusetts, north of the forty-second parallel, is crossed by several belts of hilly country which have a general northeast-southwest trend but which converge, in a way, on the rugged upland just mentioned and which separate broad tracts of lowland that are, to some extent, the valleys of the main streams of that part of the State. The only one of these hilly belts which can really be called a range extends from Shrewsbury northeastward through Harvard and Westford into Chelmsford and separates the basin of Nashua River from that of Assabet and Concord rivers. It follows a belt of metamorphosed sedimentary rock which appears to be much more resistant than the rocks on either side of it, though they are largely granitic.

East of the latitude of Marlboro and Woonsocket only small hilly tracts rise more than 300 feet above sea level (fig. 2). In the intervening tracts are scattered lower hills interspersed with rather broad lowlands, mostly sandy. As stated by Emerson, 
There is in a broad way a relation between the topography and the rock structure of this part of the State, as the hilly belts are to a large extent underlain by granites and other igneous rocks and the lowlands are more or less underlain by sedimentary rocks, but there are so many exceptions that the relation is far from being a rule.

\section{QUATERNARY GEOLOGY.}

\section{PLEISTOCENE OR GLACIAL EPOCH.}

PHENOMENA INDICATIVE OF GLACIATION.

CLASSES OF DEPOSITS.

Upon the hard rock formations throughout a large part of the northern half of the North American continent lies a mantle of unconsolidated materials of various kinds, formed during the Quaternary period. These materials may be grouped into three classes, according to the time and conditions of their deposition. The deposits cf two of these classes were formed during the Pleistocene or glacial epoch. Of these one class includes the glacial deposits, which were either formed directly through the agency of great sheets of ice that overspread the region or laid down by waters associated with these glaciers and in large part derived from the melting of their ice. These deposits are collectively termed the drift. A second class includes such deposits as were formed by various agencies during intervals when the land was free, either wholly or in part, from the dominance of the sheets of ice; these are called interglacial deposits. The third class of Quaternary deposits includes all those accumulations of material which have been formed in different ways since the latest disappearance of the great ice sheets, comprising the postglacial or Recent deposits.

\section{GENERAL CHARACTER OF THE GLACIAL DRIFT.}

The drift consists of the materials that were gathered up by the glaciers during their advance across the country, transported greater or less distances, and finally deposited by being released from the grip of the ice (Pl. X, $A$ ).

In this area good exposures of the glacial drift are numerous and easy of access, being afforded by temporary excavations, cuts for roads and railways, and erosional sections where streams are cutting the valley slopes. One of the best exposures in the vicinity of Worcester is at the brick-clay pit in the hill east of Plantation Street. Exposures in the valley bottoms consist principally of sorted and water-laid sand and gravel; those on the slopes and uplands that form the greater part of the area are made up of unsorted drift, consisting generally of a matrix of drab or dark ashen-gray clay or sandy clay in which are embedded stones of various sizes, shapes, and kinds. The finer material constituting the matrix is not a re- 
siduum from the disintegration of the underlying hard-rock formations through weathering, though in some places a small percentage of such residual material may be recognized. It is for the most part coarse rock flour, the commingled products of the abrasion of the several older rock formations of the region. The stones embedded in the matrix range in size from small pebbles to boulders weighing several tons. Most of the rock fragments in the body of the drift are less than a foot in diameter, but boulders 2 or 3 feet in diameter are of common occurrence. Among the abundant boulders on the surface of the drift, and here and there embedded in it, are masses of rock with dimensions of 10 to 20 feet. These boulders could not be transported by water currents of any ordinary strength, unless they were frozen in great masses of ice.

The arrangement of the greater part of the drift is heterogeneous, fine and coarse material, clay and boulders being intimately mixed. Such unsorted drift is known as till (Pl. IX, $A$ ). It is in striking contrast with the sorted and stratified beds produced by deposition in water. Yet from the common occurrence of stratified material in the drift it is evident that considerable water must have aided in its deposition.

The pebbles and boulders of the unstratified drift, in contrast with stones worn by fluvial or lacustrine waters, are partly angular and partly rounded, but most are subangular, with numerous flat faces. The faces usually show such polishing and parallel scratching as would result from their being held firmly in various positions and rubbed for a long time and under great pressure over hard and gritty surfaces.

At most places in this area the surface of the bedrock also, when stripped of its covering, shows well the effects of abrasive action. Instead of the gradation from solid rock to incoherent soil characteristic of regions where the soil is the residuum from the disintegration of the underlying rock, there is usually a sharp line of separation between the surface of the bedrock and the overlying drift. Unless the upper rock beds are more or less broken up they usually have smoothed and polished surfaces, marked by grooves and scratches similar to those on the pebbles and boulders in the drift (Pls. X, B, and XI). If the rock surface has not been exposed long to recent weathering the striations are sharp and distinct. They are usually nearly parallel at any given place or cross one another at low angles. Where there are slight inequalities in the surface, such as protruding knobs or jutting ledges, the side facing north is smoothed and polished, but the opposite side is rougher and more or less unmodified. In small, sharp depressions the north side is rough, but the south side is smoothed. 


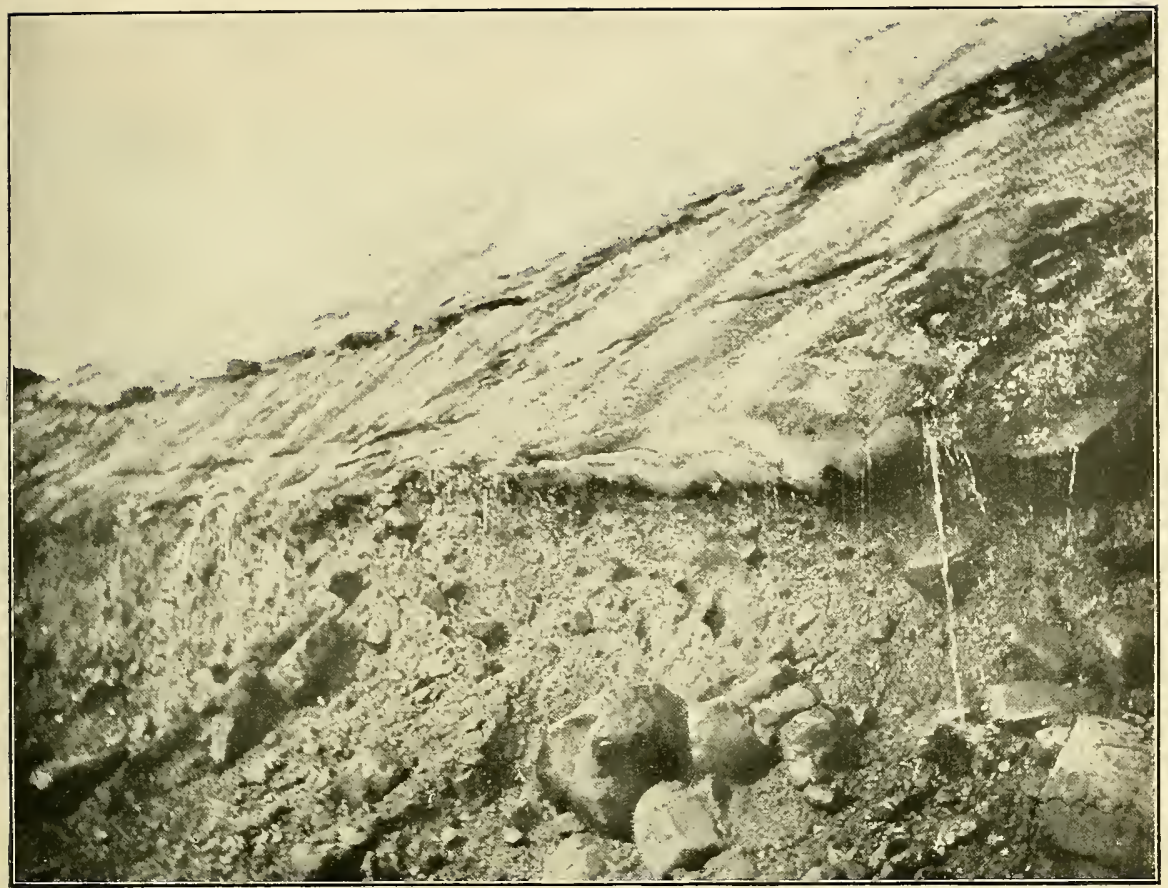

A. END OF LOWER BLASE DALE GLACIER, DISCO ISLAND, GREENLAND.

Photograph by T. C. Chamberlin.

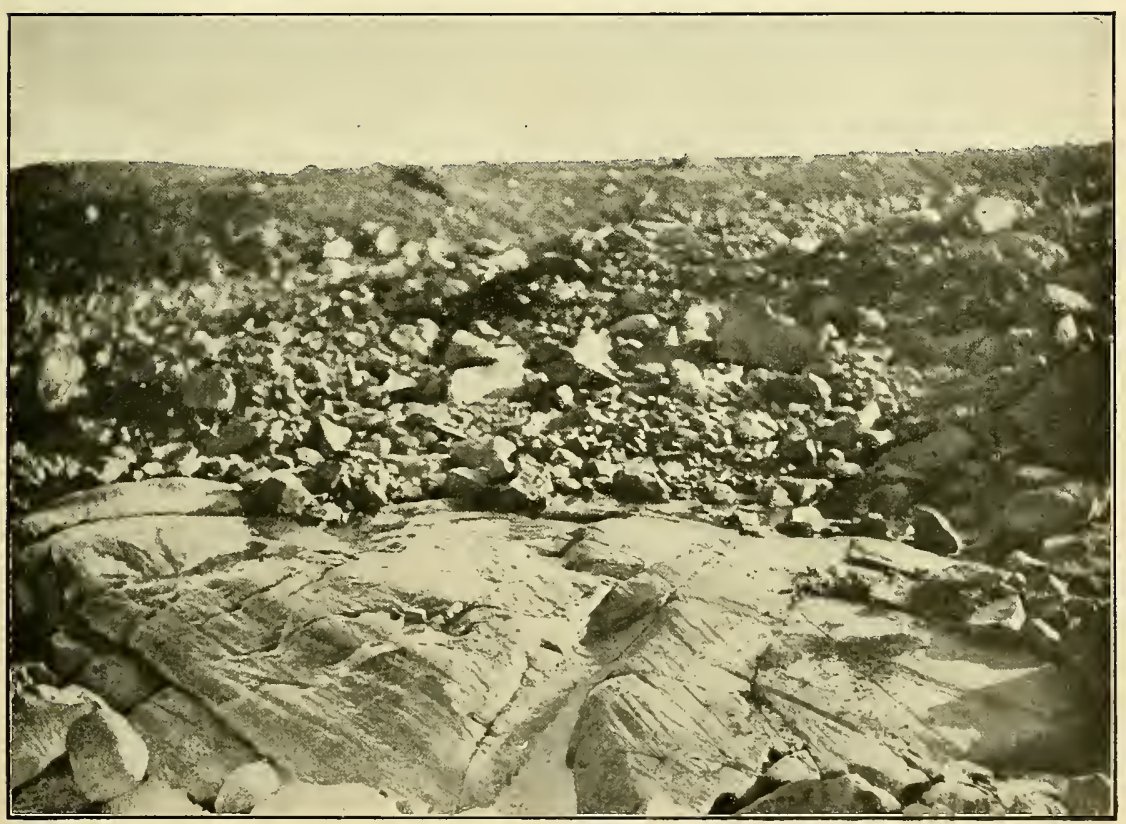

B. GLACIATED ROCK SURFACE NEAR LOWER BLASE DALE GLACIER, DISCO ISLAND, GREENLAND.

Photograph by T. C. Chamberlin. 


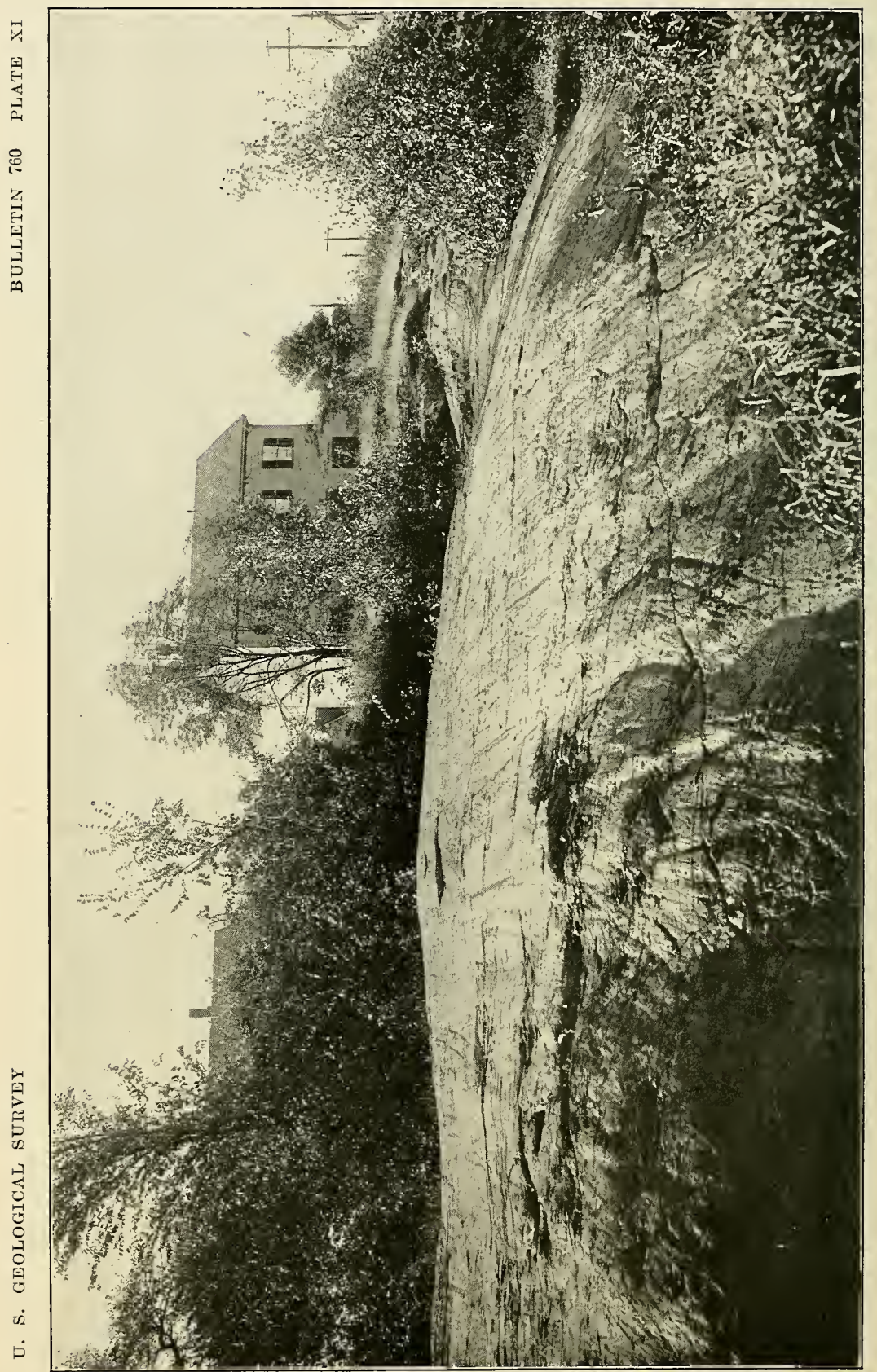


When the phenomena of the whole region are taken into consideration it becomes apparent that the glaciers depositing the drift

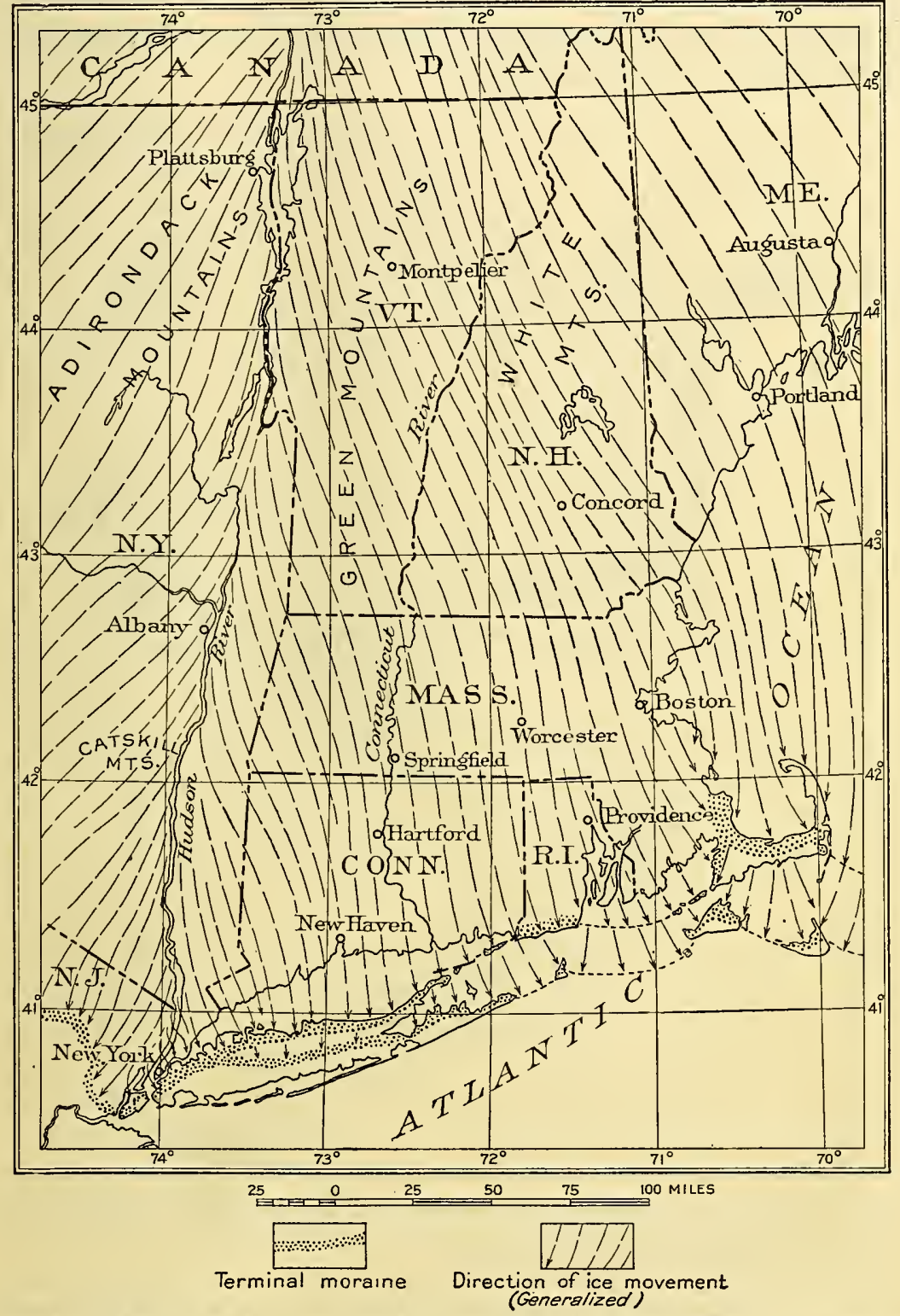

Figure 4.- Map of parts of New England, New York, and New Jersey, showing extent, directions of movement, and terminal moraines of the last great ice sheet. (Compiled by William C. Alden from observations of many geologists.)

of New England came from centers far to the north, spreading southward and southeastward over the land till they encroached upon the waters of the bordering ocean (fig. 4). 
GLACIAL AND INTERGLACIAL STAGES.

The great North American ice sheet had two main centers of growth-one west of Hudson Bay, the other on the peninsula of Labrador (fig. 5), east of the bay. The ice that invaded New England belonged to the Labrador sheet.

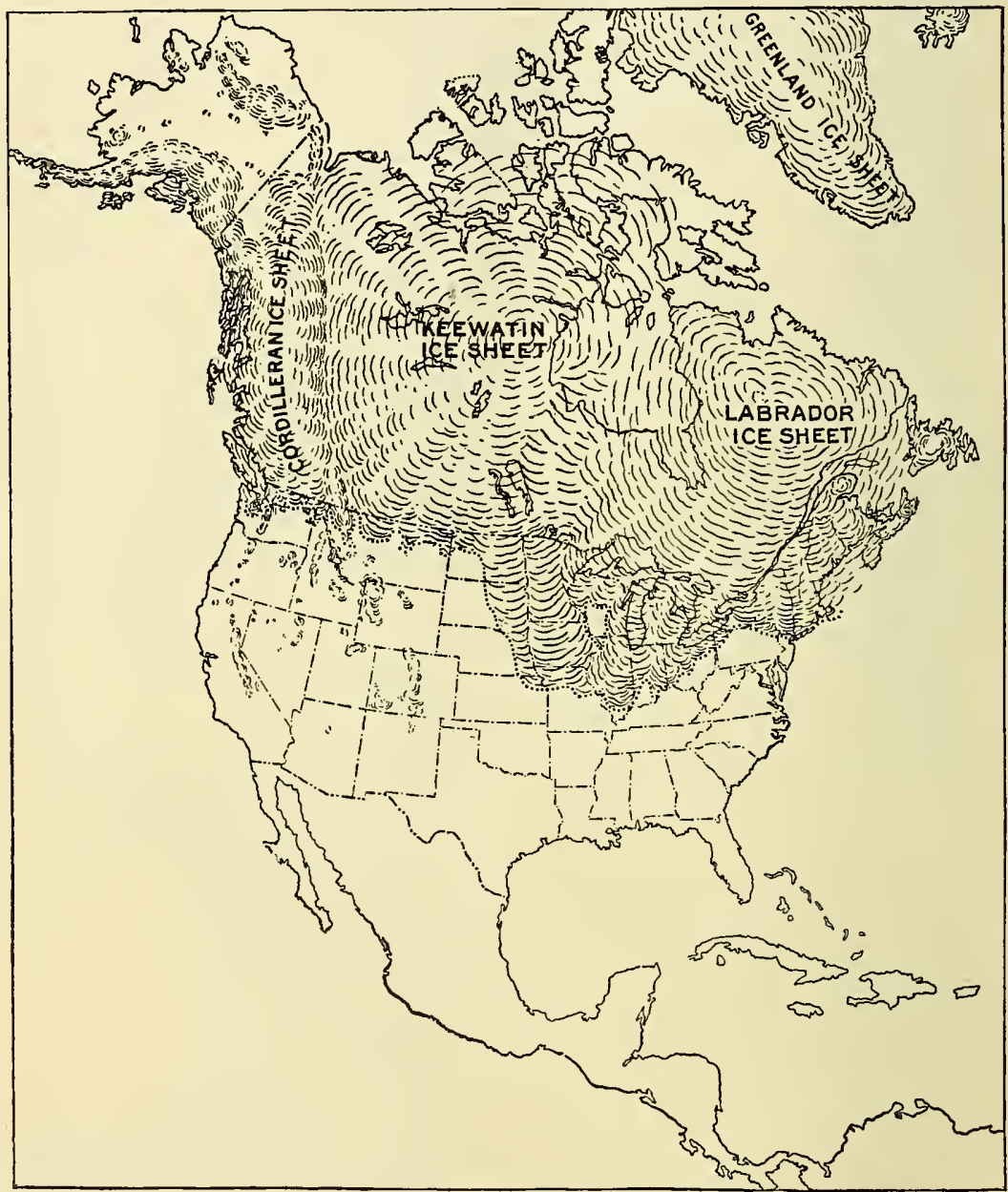

FIgURE 5.-Map showing area covered by the great ice sheets in North America at their maximum extension and the centers of ice accumulation. (Compiled by William C. Alden from observations of many geologists.)

So long as the rate of accumulation of the ice exceeded the waste by melting and evaporation the ice sheet continued to advance, but when a region was reached where the waste equaled the rate of advance the margin halted. When the waste exceeded the advance the margin was melted back. When the ice became stagnant melting caused the sheet to disintegrate in place. Periodically there were 
great oscillations of the ice front so notable in their extent and in their effects as to be designated stages of the Pleistocene epoch. During the stages of glaciation the ice advanced far to the south, driving plants and animals before it and destroying and burying in the drift such as remained. During the stages of deglaciation a reversal of these conditions took place. The climate became so much milder that the ice was melted, a new soil was developed, and plants and animals returned to their former habitats. Study of buried soils and organic remains and of the modifications which the several drift sheets have undergone as the result of exposure to the weather and to stream erosion for different periods of time has led to the determination that the Pleistocene epoch comprised a series of these glacial and interglacial stages.

The differentiation of the several drift sheets has been most clearly made out in the Mississippi Valley. Although there are reasons for believing that earlier glaciers spread over New England, it is not certainly known that more than one drift sheet, that of the last or Wisconsin stage of glaciation, is represented in central Massachusetts. So far as known to the writer, no deposits that are clearly assignable to an interglacial stage have been found in this region. Consequently, this discussion treats the glacial phenomena of the region as if they were the product of a single ice invasion-that of the WVisconsin stage.

The phenomenon of glaciation was initiated in the regions at the north by climatic conditions that resulted in vast accumulations of snow, which at length became perennial, through failure to melt entirely during the summers. As the snow piled up the light flakes changed to granules, and these in turn became coherent in a mass of porous glacier ice. Under the proper conditions of temperature, volume, gravity pressure, and slope, internal movement is initiated in such a mass so that the ice spreads from the centers of accumulation. After reaching sufficient thickness the ice front steadily advanced from the Labrador center over valley, plain, and hill and surrounded the mountain slopes until at length the vast sheet of ice even overtopped the crests of New England's highest mountains, and the Adirondacks, the Green and White mountains, Mount Katahdin, Mount Monadnock, and Wachusett Mountain all disappeared beneath it. No peak is known to have risen above the extensive plateau of ice thus formed. Figure 4 shows the general directions of movement over New England as recorded in the scorings on the surface of the rock. Though local deflections resulted from the trend of topographic features the sheet of ice as a whole moved slowly and irresistibly forward in a southeasterly direction, overriding all obstacles until it reached Long Island and the sea. 
DIRECTIONS OF THE ICE MOVEMENT.

The following observations of striated ledges indicate the directions of the ice movement within the Quinsigamond quadrangle. Beginning at the northwest, examination of the summit and slopes of Wachusett Mountain shows clearly the effects of glaciation. Where the ledges are not bare they are covered with a thin coating of gravelly till. On stripping off this coating striated surfaces of the rock are revealed.

On Wachusett Mountain a few rods east of the Summit House and near the stables striae show the following bearings: Due south, S. $15^{\circ}-18^{\circ}$ E., S. $20^{\circ}$ E., S. $30^{\circ}-40^{\circ}$ E.

'In going down the slope along the road striae were noted as follows: South side of stables, S. $10^{\circ}-22^{\circ}$ E. ; at 1,850 feet, S. $18^{\circ}$ E.; about 1,813 feet above sea level, S. $10^{\circ}$ E.; at 1,750 feet, S. $15^{\circ}$ E.; at 1,700 feet, S. $15^{\circ}$ E.; near the spring below the bend in the road at 1,556 feet above sea level, S. $25^{\circ}-30^{\circ} \mathrm{E}$.

At 500 paces to the west along the new road from the bend at 1,556 feet, striae trend S. $20^{\circ}-23^{\circ} \mathrm{W}$, and a little farther west, S. $17^{\circ} \mathrm{W}$.

This divergence is the result of deflection of the basal ice about the west slope of the mountain.

About $1 \frac{1}{4}$ miles farther south stripping for the new road 40 rods north of the corner exposed glaciated ledges with striae trending S. $15^{\circ}-26^{\circ} \mathrm{E}$.

Princeton Township, road on north slope of Calamint Hill, S. $28^{\circ}$ E.

Rutland Township, 1 mile southeast of West Rutland, S. $70^{\circ} \mathrm{E}$.

Leominster Township, road on south slope of Bee Hill, S. $20^{\circ} \mathrm{W}$.

Boylston Township, 2 miles southwest of Clinton, on road to West Boylston, upturned edges of Worcester phyllite smoothly planed and striated, S. $12^{\circ} \mathrm{W}$.

Clinton, half a mile east of Wachusett dam, at east entrance to Boston \& Maine Railroad tunnel, S. $2^{\circ}-3^{\circ} \mathrm{W}$.

Bolton Station, smoothly glaciated ledge just south of railroad crossing, S. $2^{\circ}-12^{\circ} \mathrm{E}$.

At Clinton, about 120 rods north of the railroad station, where the creek crosses North Main Street, is the finest glaciated ledge observed within the Quinsigamond quadrangle ( $\mathrm{Pl}$. XI). The prevailing trend of the striae is $\mathrm{S} .7^{\circ}-12^{\circ} \mathrm{W}$. In running diagonally up the lower north slope of the smoothly rounded ledge the striae have a more southwesterly trend, which shifts gradually to a more southerly trend as the abrupt 5 or 6 foot slope is surmounted. Readings at intervals of a few feet from north to south along these curved lines show the following changes of direction:
S. $32^{\circ}$ W.-S. $26^{\circ}$ W.-S. $13^{\circ}$ W.
S. $26^{\circ}$ W.-S. $4^{\circ}$ W.-S. $2^{\circ}$ E.
S. $40^{\circ}$ W.-S. $20^{\circ}$ W.-S. $14^{\circ}$ W.
S. $40^{\circ}$ W.-S. $20^{\circ}$ W.-S $7^{\circ}$ W.
S. $32^{\circ}$ W.-S. $26^{\circ}$ W.-S. $13^{\circ}$ W.
S. $27^{\circ}$ W.-S. $2^{\circ}$ W.
S. $26^{\circ}$ W.-S. $4^{\circ}$ W.-S. $2^{\circ}$ E.

Higher up the top slope from the last reading and crossing were striae trending due south, S. $3^{\circ}$ E., S. $7^{\circ}$ E., and S. $12^{\circ} \mathrm{W}$.

Numerous other glaciated surfaces were temporarily exposed in the excavations for the north-dike cut-off of Wachusett Reservoir.

One mile east of Boylston Center, S. $3^{\circ}$ W. (Emerson).

At Southboro, on Main Street, about three-quarters of a mile west of the center of the village, is a fine example of the results of glaciation. The sur- 
face of the ledge of schist is smoothly rounded, grooved, and scratched with striae ranging from S. $2^{\circ}$ E. to $\mathrm{S} .10^{\circ} \mathrm{W}$.

In Worcester and vicinity the effects of glacial abrasion can usually be seen wherever the drift covering is stripped from the rock. Striae bearing $S$. $5^{\circ}-10^{\circ} \mathrm{W}$. were observed by the writer on the planed edges of the upturned phyllite schists a short distance west of the Plantation Street viaduct over the Boston \& Albany Railroad, south of the State Insane Hospital.

In the southwestern part of Worcester, at the cemetery Notre Dame des Canadiens, opposite Hope Cemetery on Webster Street, a glaciated ledge of schist was observed just south of Rev. J. Brauillet's monument, with striae bearing due south to $\mathrm{S} .10^{\circ} \mathrm{E}$.

In the southeastern part of the village of Upton is a ledge of gneiss whose surface is grooved in a direction S. $2^{\circ}-10^{\circ} \mathrm{W}$. The surface is so much weathered, however, that it is uncertain whether the markings are the result of glaciation.

About $1 \frac{1}{2}$ miles farther southeast ledges beside the road show striae trending S. $17^{\circ} \mathrm{E}$.

In Woonsocket, R. I., one block west of the railroad station, a glaciated ledge of schist and conglomerate is exposed in the east slope of the valley.

Striae having a southerly trend were reported by Robert Robertson in the town of Auburn, on the road half a mile northeast of Auburn Station, and also in the town of Woodstock, Conn., 1 mile west of the village of Quinebaug.

Edward Hitcheock ${ }^{12}$ cites glacial striae trending nearly due south on the eastern slope of a hill in the southeastern part of Sutton.

Glacial striae have been found in the Ware quadrangle as indicated below.

Granby Township, south of the east end of the Holyoke Range, S. $8^{\circ}$ E. (B. K. Emerson).

Granby Township, west end of Forge Pond, S. $15^{\circ}$ E. (B. K. Emerson).

Pelham, west slope of ridge, 1 mile north of Hygeia, S. $15^{\circ}$ W. (B. K. Fmerson).

$1 \frac{1}{2}$ miles northeast of Dwight station, N. $80^{\circ}$ E. (G. H. Barton).

Petersham, S. $5^{\circ}-20^{\circ}$ E. (G. H. Barton).

2 miles southwest of Petersham, south of Fever Brook bridge, doubtful, S. $10^{\circ}$ W. (W. C. Alden).

3 miles northwest of Barre, S. $10^{\circ}$ E. (G. H. Barton).

$1 \frac{1}{2}$ miles north-northwest of Barre, north slope of Allen Hill, S. $10^{\circ}$ E. (G. H. Barton).

$2 \frac{1}{2}$ miles southwest of Barre, crest east of Pine Hill Brook, S. $50^{\circ}$ E. (W. C. Alden ).

$1 \frac{1}{2}$ miles north of Furnace, S. $7^{\circ}-10^{\circ}$ W. (W. C. Alden).

$1 \frac{1}{4}$ miles north of Oakham, S. $1^{\circ}$ E. (N. S. Shaler's assistants).

$1 \frac{1}{4}$ miles southeast of Ware, west slope of Coy Hill, S. $10^{\circ}$ E. (G. H. Barton).

$1 \frac{1}{2}$ miles north of Palmer, north of C. Kalliher's, S. $40^{\circ}$ E. (B. K. Emerson).

3 miles south-southeast of Brookfield on ridge crest, S. $15^{\circ}$ W. (W. C. Alden).

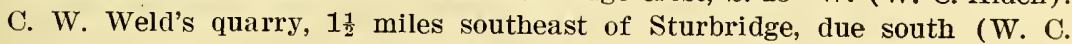
Alden).

3 miles southwest of Southbridge, south-southwest (W. C. Alden).

As indicated by the trend of the striae and by the orientation of the elongated drift hills, or drumlins, shown on the maps, the general

12 Final report on the geology of Massachusetts, vol. 2, p. 387, 1841. 
direction of the ice movement across the area was southerly, with local deflections to the southeast and southwest. In the western part of the area the southerly movement was doubtless controlled by the great valley of the Connecticut. That there was comparatively little movement of the basal ice eastward or southeastward from the valley to the uplands on the east is indicated by the rarity of fragments of the Triassic sandstone and conglomerate in the drift of the Pelham ridge.

\section{THICKNESS OF THE ICE.}

Concerning the probable thickness of the ice at the time of its maximum extension, which is believed to be marked by the outer terminal moraine on Long and Block islands, Marthas Vineyard, and Nantucket, certain deductions may be made. Measured on an air line in the direction of the ice movement, Wachusett Mountain stands about 90 miles from the moraine on Block Island. As the summit of this peak, which stands 2,015 feet above sea level, was glaciated the ice must have been at least thick enough to cover the summit, and it was probably considerably thicker. On the assumption that the relative altitudes were about the same as at present, the average slope of the ice surface from the terminal moraine on Block Island must have been about 22.4 feet to the mile in order to cover the summit of the peak; if the average slope was 25 feet to the mile the summit must have been buried under 235 feet of ice, a thickness not at all improbable. Mount Monadnock, with its glaciated summit 3,166 feet above sea level, stands about 118 miles from the terminal moraine, measured along a line only a short distance west of that from Wachusett Mountain. To surmount this peak the average slope of the surface of the ice must have been about 26.75 feet to the mile, a slope which would have required about 400 feet of ice on the summit of Wachusett Mountain and 1,450 to 1,550 feet over the site of Worcester. An average slope of 30 feet to the mile, such as was estimated by Smock ${ }^{13}$ from data obtained in Jew Jersey and adjacent parts of New York, would have given the ice plateau above Mount Monadnock an altitude of 3,540 feet, covering the summit to a depth of 374 feet. The crest of Wachusett Mountain would have been buried to a depth of 685 feet, and at Worcester the ice would have been 1,700 to 1,800 feet thick.

In existing ice caps, such as that of Greenland, the slope of the surface, which is abrupt at the margin, becomes much less as distance from the margin increases. In Montana Calhoun ${ }^{14}$ obtained evi-

${ }^{13}$ Smock, J. C., On the surface limit or thickness of the continental glacier in New Jersey and adjacent States: Am. Jour. Sci., 3d ser., vol. 25, p. 339, 1882.

${ }_{14}$ Calhoun, F. H. H., The Montana lobe of the Keewatin ice sheet: U. S. Geol. Surves Prof. Paper 25, p. 28, 1906. 
dence concerning the marginal slope of the Keewatin ice sheet from which he drew the following conclusions:

In the Pondera Basin the slope was about 30 feet to the mile. On Teton Ridge the slope, much less exactly determined by the slope of the moraine, was about 40 feet per mile, and on the slope of Milk River ridge it was 50 feet per mile. The most satisfactory determination was made between the Sweet Grass Hills and the edge of the ice to the west. *** In this distance [25 miles] the slope of the upper surface of the ice averaged about 50 feet per mile.

If the average slope is assumed to have been 50 feet to the mile for the first 25 miles north of the moraine on Block Island and 22.3 feet to the mile for the remaining 65 miles to Wachusett Mountain, making an average of 30 feet to the mile for the whole distance of 90 miles, the ice plateau in the southern part of the Quinsigamond quadrangle would have had an altitude of about 2,365 feet, and there would have been a thickness of 1,800 to 1,900 feet of ice over the city of Worcester. Although these estimates give concrete expression to conceptions concerning the magnitude of the ice sheet, it can not be assumed that they approach exactness, because of the unknown factors involved, such as the attitude of the land surface in Pleistocene time.

\section{PRE-WISCONSIN DEPOSITS.}

LACUSTRINE CLAY.

At only one place in the Ware and Quinsigamond quadrangles were materials observed that might be regarded as evidence of a stage of glaciation and deglaciation earlier than that during which the main deposit of drift was laid down. About a mile southwest of Larnedville, at the east side of Little River valley, the Worcester \& Southbridge Electric Railway traverses a cut in the south end of the ridge. The cut, which is divided by a slight ravine, has a maximum depth of 50 feet. At the time of the writer's visit the section was partly obscured by wash and a slide, so that the relations of the materials were not entirely clear. In the eastern part of the cut there was exposed at the top 15 feet of sand and gravel, with a few boulders, poorly assorted and obscurely bedded. Below this was 15 feet of fine interlaminated sand and gray clay, intensely contorted (Pl. XII, $A$ ). The remaining 5 feet of the cut below this was obscured by talus. The laminated sand and clay formed the core of the section, and the surface sloped down to the east and west, so that the overlying gravelly drift extended down on either side to the bottom of the cut. Farther west down the track in the other part of the cut the contorted laminated materials extended to a level 10 feet lower and formed a core 20 feet in height. Mantling the curving surface of these deposits was 30 feet of sandy 
gravel drift. The drift here includes beds of clean sand, but elsewhere it is unsorted and appears to consist of pebbly and bouldery till, with a matrix of loose sand. The base of the laminated clay was not clearly exposed, but at one point it appeared to rest on sandy till, cemented so thoroughly as to be difficult to penetrate with a pick. The opposite side of the cut appeared to be made up almost wholly of sandy till. The altitude of the top of the laminated beds is about 640 feet above sea level, and the cut is in the south slope, facing an open valley leading southward, so that under present topographic conditions ponded waters in which the fine laminated silts might be deposited could not be held up to the level of the beds exposed. The relations of these deposits are so obscure that accurate conclusions can not be based upon them. They seem to indicate that the glacier advanced, depositing the underlying till; that this was followed by melting of the glacier, which left the basin closed by drift or ice in such a way as to pond the waters and deposit the silts; and that subsequent draining of the basin resulted in erosion of the laminated deposits. A readvance of the ice contorted the laminae, and the final melting left the upper sandy till. The underlying till was insufficiently exposed to determine whether or not it belonged to a stage distinct from that at which the main till sheet was formed. The laminated silts and the few included crystalline pebbles seen did not give evidence of exposure to the weather prior to the last advance of the ice, so that the events recorded here may be merely the results of conditions resulting from minor oscillations of the ice front, rather than of distinct succeeding stages of glaciation and deglaciation.

\section{RESIDUAL MATERIAL.}

Throughout most of the area the rock surface beneath the drift is smoothly planed, or even polished, and striated, and the residuum of preglacial weathering has been entirely removed. At a few places, however, considerable residual material has been incorporated in the drift, and some yet remains undisturbed between the drift and the solid rock. One such exposure was seen on the road traversing the slope half a mile southwest of Uxbridge, where 1 foot of sandy till overlies 3 to 5 feet of distintegrated gneiss.

Near the crossroads half a mile east of the south end of Whitehall Pond a 15-foot exposure in the north slope of the hill showed the following relations: A mass of granite and gneiss with rounded surfaces rises 10 feet into the section. At one side is compact brownishgray till, which is penetrated by a pick with difficulty. Overlying the rounded surface is a few inches of stratified sand. At the other side, overlying the sand and rock, is 5 to 10 feet of arkose, or sand resulting from the distintegration of the gneiss. No drift material 


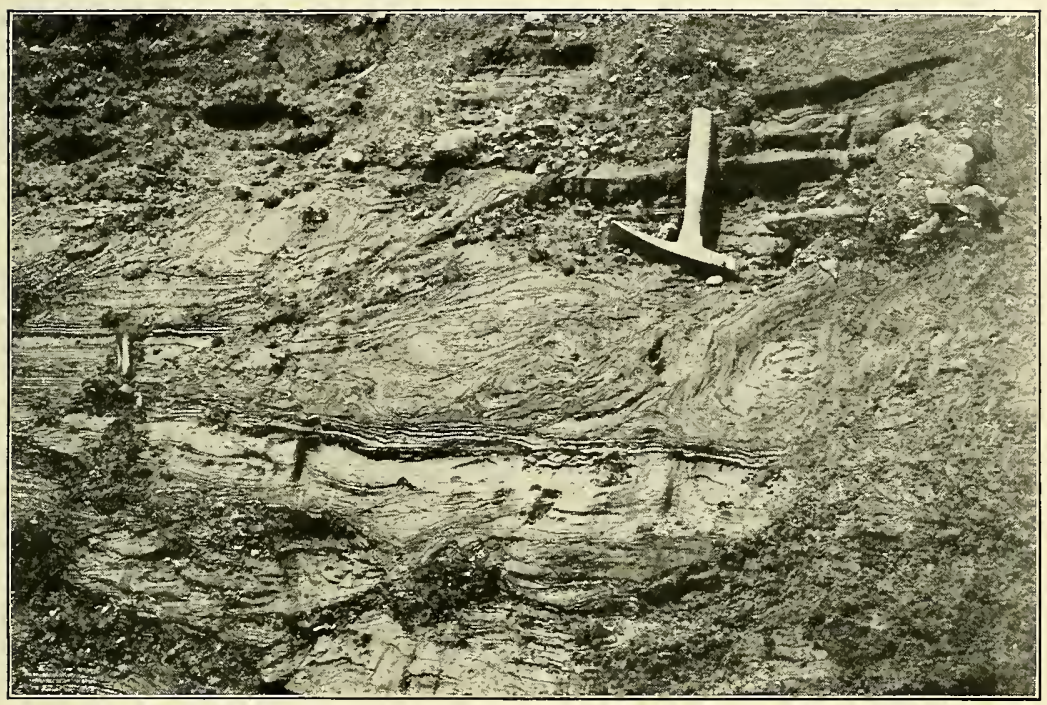

A. CRUMPled LAMiNATED CLAY, POSSIBLy INTERGLACIAL.

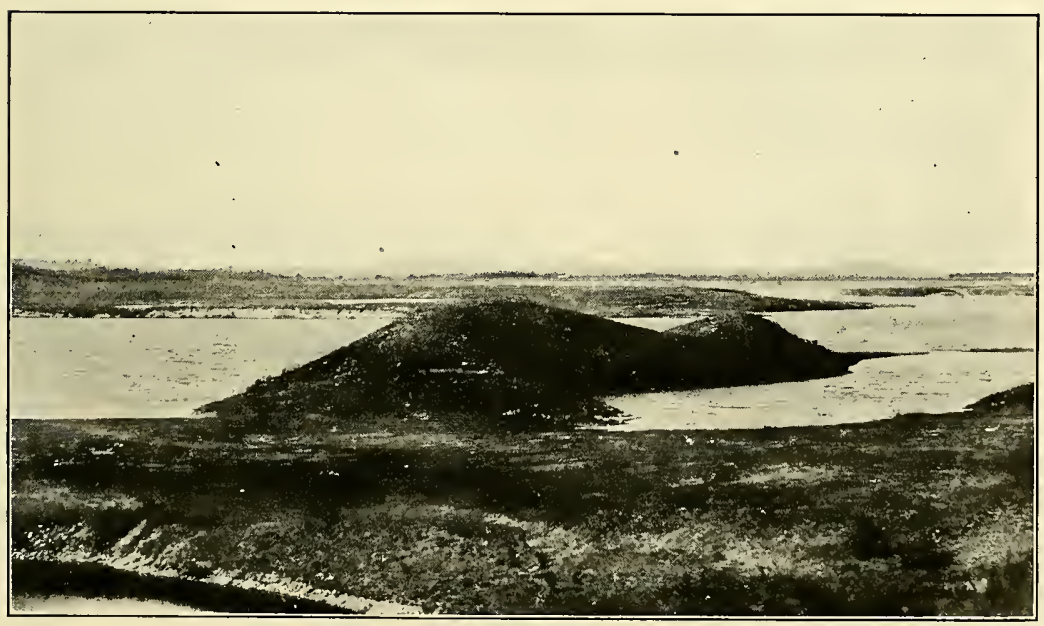

B. ESKER SOUTH OF CLINTON, MASS. 



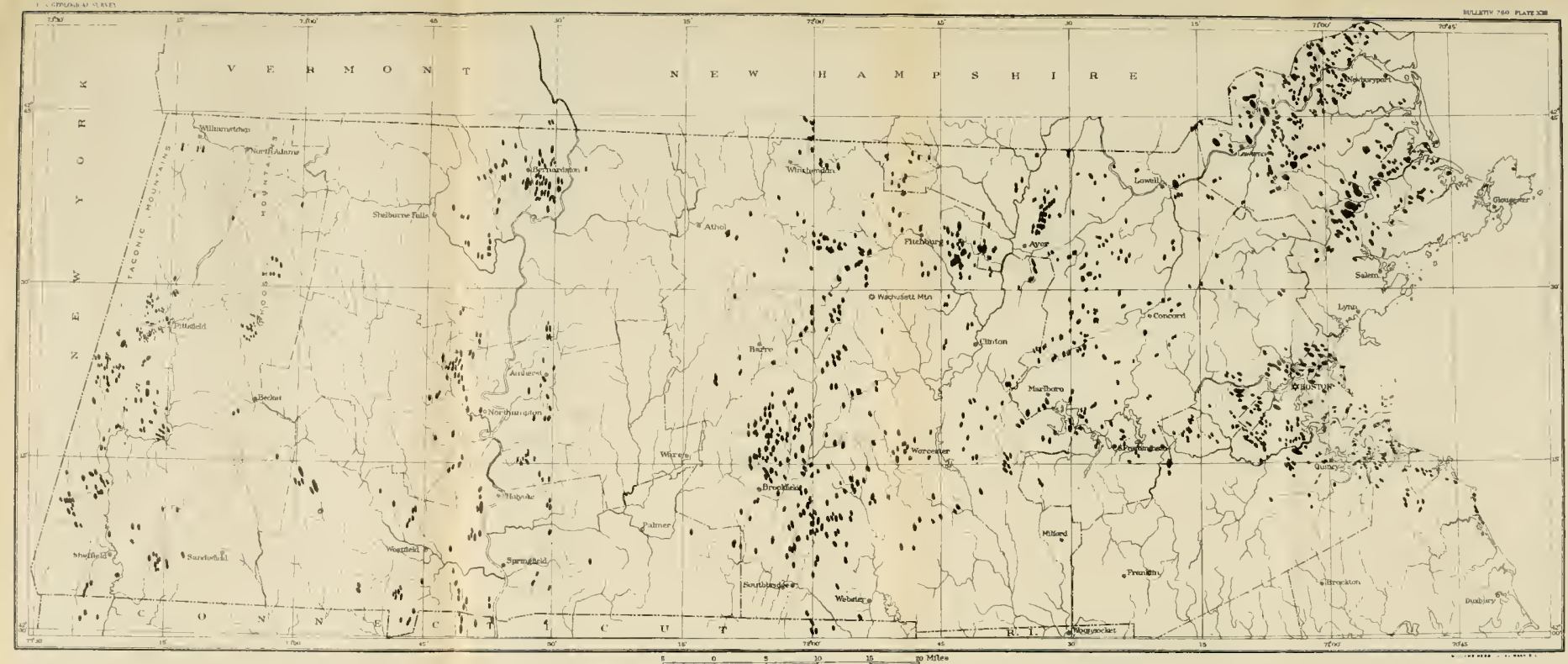





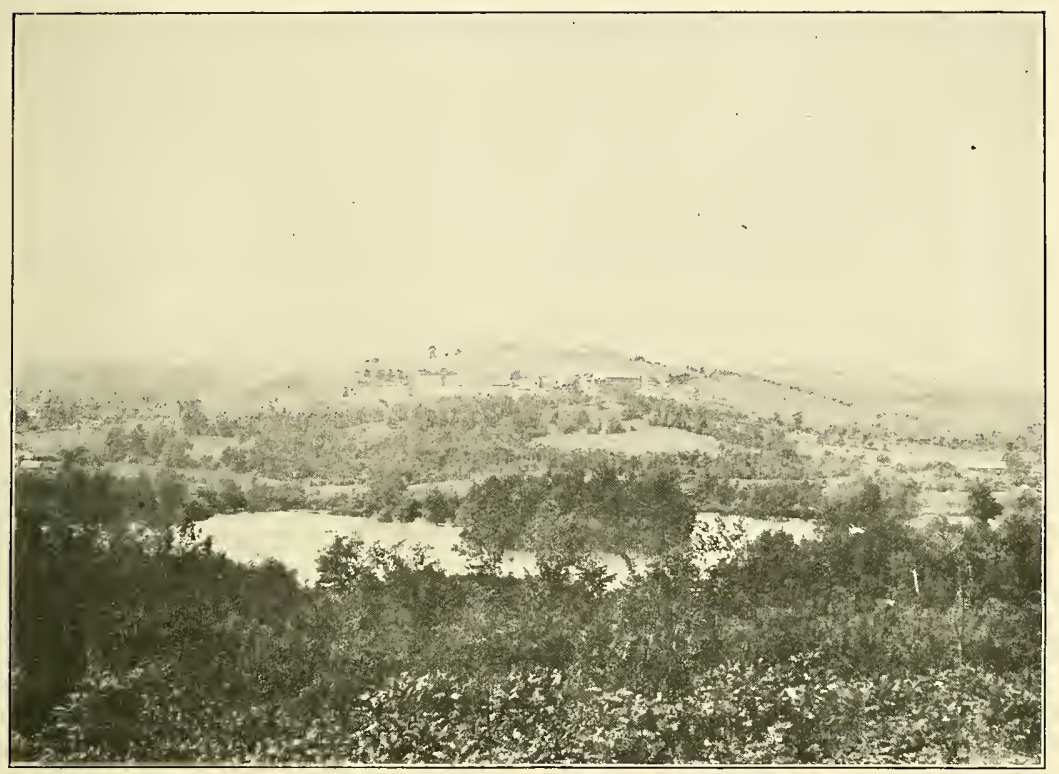

a. PROSPECT HILL, A DRUMLIN NEAR CHARLTON, R.ASS.

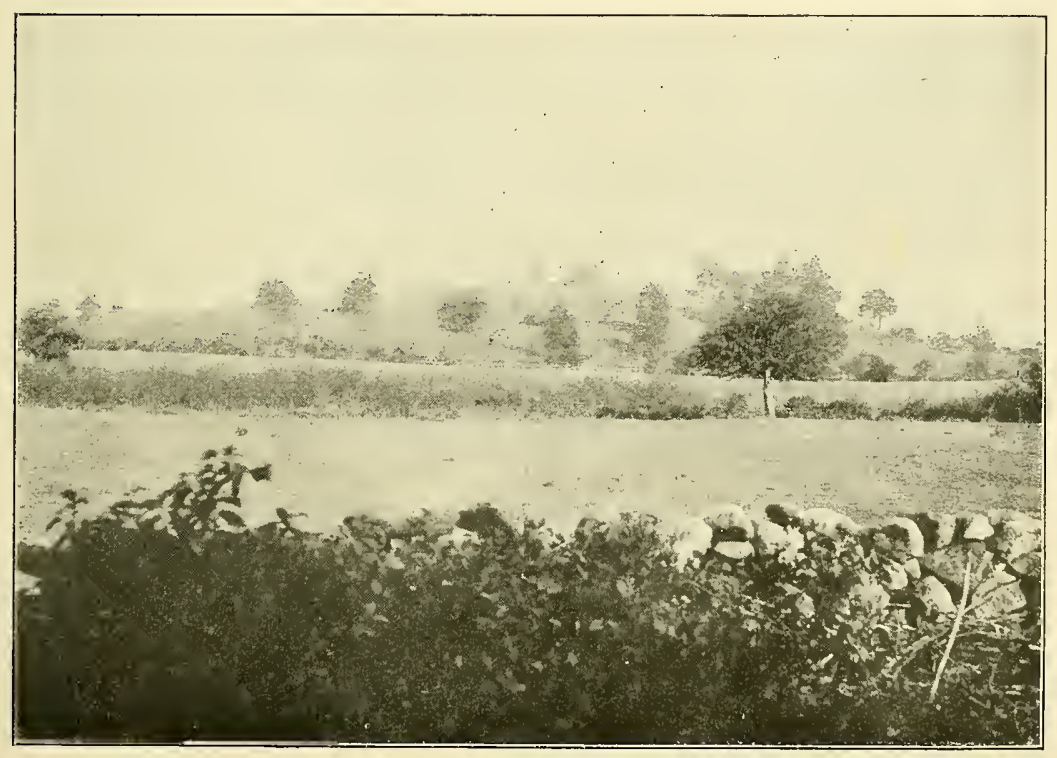

B. DRUMLIN NORThEAST OF GLEASONDALE, MASS. 

is commingled with this sand. The cleavage is clearly traceable, and a quartz vein 1 inch thick extends vertically through it for 2 or 3 feet. The quartz of this vein preserves its alinement, though broken into fragments, showing that the material has not been disturbed since its disintegration, unless it was moved as a whole when cemented by ice.

At Joseph Bugbee's, 2 miles south of North Braintree, in the Ware quadrangle, is exposed about 15 feet of thoroughly distintegrated brown coarse-grained schist, which is probably preglacial residuum.

About $2 \frac{1}{2}$ miles northwest of Barre an excavation in the east slope of Moose Brook valley gave the following section:

\section{Section of drift northuest of Barre.}

Buff sandy, bouldery till__a $r$

Gray disintegrated" schist, with some till mixed in upper part__ 7

This material grades downward into solid undecomposed schist. The upper part of the distintegrated schist is somewhat disturbed and contains undecomposed fragments, and the till consists almost entirely of local material, so that the two are scarcely distinguishable.

\section{WISCONSIN DRIFT.}

\section{THE GROUND MORAINE.}

GENERAL CHARACTER.

Overlying the uneven surface of the indurated rock formations throughout the two quadrangles is a mantle of till composed of heterogeneously mixed clay, sand, gravel, and boulders of various lithologic character. Most of this material probably lodged beneath the advancing glacier as ground moraine. Some of it, together with most of the boulders scattered on the surface, was deposited when the ice finally melted away. This deposit is generally thin upon the crests and slopes of the ridges, where rock ledges are exposed at short intervals. The valleys are largely occupied by glacial stream deposits laid down during the melting of the ice. At a few places 30 to 50 feet of unstratified till is exposed, and some wells are known to have penetrated 90 to 100 feet of drift, of which at least a large part is probably till. Numerous local accumulations of drift also occur as drumlins and drumloidal hills 20 to 150 feet in height, which may be composed almost wholly of till. It is doubtful, however, if the average thickness of the drift in central Massachusetts is more than 10 or 15 feet, and it may be less. Though the matrix is generally a compact clayey till, on close examination it is seen to be made up of rather coarse undecomposed or partly decomposed grains of $92817^{\circ}-24-3$ 
crystalline rocks. This being the case, the upper part is likely to be loose and sandy. The difference in texture of the upper part is also accompanied by a change in color, from the prevalent dark gray of the lower part to light buff or grayish buff. This difference in texture and color is partly a result of weathering and partly a consequence of the fact that the last contribution of the melting glacier, when the advance had ceased, escaped the compression consequent on being overridden by the ice. The depth of the looser weathered zone is rather variable. In places the gray tint extends upward to the grass roots. Elsewhere the gradation from gray to buff occurs at depths of 3 to 10 or even 15 feet. The change is everywhere a gradation; at no place does the upper buff part of the till appear to be a distinct deposit.

The till is composed predominantly of rock material of local character. It contains comparatively few rock fragments that can not have been derived from formations exposed within the immediate region, and usually the till is composed largely of rock such as occurs directly beneath or very near the exposure. Over the belts of granite and gneiss the till is light gray and consists largely of granitic material. Over the schist the till is more brownish, and schistose fragments prevail. Over the phyllite the matrix is apt to be more compact and in places has a greenish tint.

Besides being compact and difficult of excavation the till may show a rude cleavage parallel to the surface, evidently the result of pressure of overriding ice. Other than this cleavage the typical till shows no definiteness of structure. It is not uncommon, however, for associated sand and gravel to occur in lenses or layers in the midst of the till, or for the material to be semistratified throughout, showing the close association of ice and water action in the process of deposition. In some places bands of associated material are crumpled and kneaded in with the till, as if it had been disturbed by the forward crowding of the ice. Generally the rock fragments in the till are fresh and sound and retain the marks of glacial abrasion. Locally, however, it contains crystalline pebbles that are in a stage of incipient disintegration, so that they crumble beneath the hammer. Throughout most of the area the residuum of preglacial weathering has been entirely removed, but at a few places considerable residual material has been incorporated in the till, and some yet remains undisturbed between the till and the solid rock.

DRUMLINS.

The general topographic expression of the ground moraine is that of a mantle, which has smoothly flowing contours where it covers the rock ridges with sufficient thickness to disguise their angularities. 
In places, however, local thickening of the drift sheet results in certain more or less distinct topographic features of its own. These are the drumlins, the distribution of which throughout Massachusetts is shown in Plate XIII. About 275 of those in the area under discussion are sufficiently well formed to be indicated on the detailed map (Pl. VI, in pocket). In this mapping the writer's observations have been supplemented by those of Prof. George H. Barton, as shown on unpublished maps. Though scattered through much of the eastern two-thirds of this area, they are most numerous in the eastern part of the Ware quadrangle and the western part of the Quinsigamond quadrangle. Besides those mapped, other hills, apparently of drift, show drumloidal profiles as seen from one direction, but their contours do not conform to the drumlin type as known in various parts of the country. The drumlin is a product of the glacial advance, the overriding ice tending to give to the accumulation of drift a form that offers relatively small resistance to the forward movement of the ice. As a result of his observations and studies, particularly in Wisconsin, the writer has come to regard as a typical drumlin a hill of glacial drift that approximates the form of a segment of an elongated ovoid of which the widest part of the basal outline and the highest point of the crest are not more distant from the stoss endthat is, the end that was opposed to the ice advance-than one-third the length of the major axis, and whose major axis is oriented parallel to the direction of the movement of the glacier that formed it. Most drumlins, however, vary more or less from any set type, and there is also some difference of opinion among geologists as to the use of the term "drumlin," some including under this designation hills of glacial drift that have little definiteness of form or regularity of orientation. Owing to this difference of interpretation, maps of the same area by different workers may not entirely agree in the hills shown as drumlins. Though by no means wishing to limit the use of the term to typical forms such as are defined above, the writer regards approximately oval or elliptical contours and orientation of the longer axis approximately parallel to the direction of ice movement as essential characteristics of this class of hills. The drift hills of other forms and orientation are not here included.

The graceful contours of the drumlins add much to the beauty of the landscape, the most striking feature being the regular curves of the crest line (Pl. XIV, $A, B$ ), as seen in either longitudinal or transverse profile. The basal outline as drawn upon the map may appear distorted, because of the inequalities of the surrounding surfaces to which the side slopes decline. Usually contour lines above the base are more regular than the line marking the foot of the slopes. For a comparison of the dimensions of the 146 drumlins of the Ware quadrangle with the 160 drumlins of the Quinsigamend 
quadrangle rough measurements were made on the topographic maps on a scale of $1: 62,500$, referred to on page 14 . The results are presented in the following tables:

Dimensions of drumlins in the Ware and Quinsigamond quadrangles.

\begin{tabular}{|c|c|c|c|c|c|}
\hline & $\begin{array}{c}\text { Ware } \\
\text { quad- } \\
\text { rangle. }\end{array}$ & $\begin{array}{l}\text { Quin- } \\
\text { sigamond } \\
\text { quad-- } \\
\text { rangle. }\end{array}$ & & $\begin{array}{l}\text { Ware } \\
\text { quad- } \\
\text { rangle. }\end{array}$ & $\begin{array}{l}\text { Quin- } \\
\text { sigamond } \\
\text { quad- } \\
\text { rangle. }\end{array}$ \\
\hline 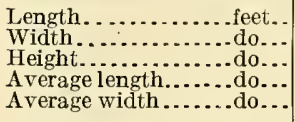 & $\begin{array}{r}1,050-4,755 \\
415-2,310 \\
15-180 \\
2,505 \\
1,200\end{array}$ & $\begin{array}{r}825-4,950 \\
495-4,125 \\
30-245 \\
2,805 \\
1,485\end{array}$ & $\begin{array}{l}\text { Average height....... feet.. } \\
\text { Ratio length to width.... } \\
\text { Ratio length to height..... } \\
\text { Ratio width to height..... }\end{array}$ & \begin{tabular}{r|}
56 \\
2.8 \\
44.5 \\
21.5
\end{tabular} & $\begin{array}{r}100 \\
1.8 \\
26 \\
14\end{array}$ \\
\hline
\end{tabular}

From this comparison it appears that the drumlins of the Ware quadrangle are on the average somewhat smaller and relatively more slender than those farther east. There is, however, so much variation in both quadrangles that the difference is not at all marked.

Perhaps the type defined above is too restricted. In this area the tendency is toward elliptical rather than oval contours, and several hills are approximately circular, the diameters being nearly equal in all directions. Most of the drumlins are elongated in the direction of the ice movement, but there is a notable absence of those forms in which the lee ends are drawn out into long tapering tails. The crests of a few of the drumlins are cut by channels of subsequent formation. The character and relations of these channels are discussed below, in connection with the description of eskers.

In only one drumlin within the area was there noted a good exposure of the internal structure at the time of the writer's examination. This is the drumlin east of Plantation Street in Worcester. This hill has a height of about 90 feet. In the lower west slope a large excavation has been made for brick clay, giving a 50-foot section. No ledge of rock is exposed, the whole face being solid dark-grayish till, hard to dig with a pick, except the upper 5 to 8 feet, where the till is lighter in color, or dull buff, and of somewhat looser texture. Most of the pebbles are 2 to 4 inches in size, though a few boulders were seen, including one 8 feet in length. No assortment, bedding, or other evidence of water action was noted, but an indefinite cleavage due to pressure is present. 'There is no evidence that the hill has a rock core, though the presence of exposed ledges within distances of 1,350 feet or less in almost every direction makes it probable that bedrock lies not far below the base of the drumlin. Similarly, in the slopes of the other hills regarded as drumlins no ledges were exposed, though rock crops out within short distances of the bases of many of them. Though the absence of rock cores has not been proved, the drumlins are believed to be made 
up wholly of glacial drift. As will be seen from the map, the orientation of most of the longer axes is approximately parallel with the directions of striae observed on glaciated rock ledges. These show that the ice moved across the area in a general southerly direction. There is, however, considerable local divergence, some axes swinging off $50^{\circ}$ to $70^{\circ}$ east of south. Throughout the district there is a general development of smoothly rounded and elliptical crests, but examination shows that most of the hills and ridges not mapped as drumlins are composed of abraded rock ledges only thinly covered with drift. The drumlins appear to be local accumulations of till that have been symmetrically molded by the moving ice. The particular causes that led to such accumulations in one place rather than another are not well understood, although there has been a good deal of speculation among geologists in regard to this matter. Many of the drumlins appear as lobes of the lateral or terminal slopes of ridges of the dissected upland in such a position that they might well be regarded as but thinly veneered lobes of rock. The only reason for considering these hills to be drumlins is their form and the absence of outcropping rock in them. Indeed, without test borings it is quite impossible to determine that the hills have no rock cores, for practically all stand on bedrock bases.

The drumlins occur indiscriminately in all sorts of topographic situations-on broad upland crests, in narrow valleys lying alongside slopes of broad rock ledges with one lateral slope much longer than the other, banked against the rising north slopes of rock elevations, or tailing down the lee south slopes to lower levels.

\section{TERMINAL MORAINES.}

MODE OF OCCURRENCE.

Whenever the rate of melting of the ice became approximately the same as the rate of forward movement, the glacial margin either halted or oscillated back and forth over a narrow belt of country, and the drift brought forward and released there tended to accumulate in the form of a more or less irregular ridge or range of hills, known as a terminal moraine. The main terminal moraines that mark the outer limit of advance of that part of the ice sheet which traversed this region lie to the south, on Long Island, Block Island, Marthas Vineyard, and Nantucket, and partly on the coast (fig. 4). Such moraines were also formed at stages of halt or of readvance and halt of the ice margin, which interrupted the general northward recession of the ice front across the country during the final melting of the glaciers, and these terminal moraines have been designated moraines of recession. No continuous, well-defined terminal moraines have been traced across the Ware and Quinsiga- 
mond quadrangles, though numerous isolated deposits of drift occur which if properly correlated with other features give some clue concerning the configuration of the glacial margin and the process of final deglaciation in the area. The distribution of these deposits is shown on the maps, and lines showing a provisional correlation of these with other features of the district are shown on Plate VII (in pocket). Topographically these deposits are very insignificant, so that their presence would scarcely be noted except by one making a systematic study of the country, yet geologically they are of some importance. In regions where the inequalities of the preglacial topography are largely obliterated by a heavy mantle of drift the moraines formed at the several positions of halt of the ice front are usually distributed along lines transverse to the direction of the ice advance, forming more or less continuous marginal moraines. In this area, on the contrary, where the valleys and ridges developed prior to the ice invasion were simply mantled by the drift and are still the predominant topographic features, almost all the deposits, of whatever character, formed in connection with the retreat of the ice front are distributed along the valleys approximately parallel to the direction of the ice advance, rather than along the transverse lines that must have defined the retreating margin. The correlation of these features is considered below, in the discussion of the Pleistocene history (pp. 93-104).

Two examples of transverse moraines were observed 3 to 6 miles southeast of Wachusett Mountain. From a point $1 \frac{1}{4}$ miles south of West Sterling a belt of sags and low gravel swells may be traced from the bottom of Stillwater Valley southwestward up the slope and across the crest to the valley of Governor Brook, and thence across the south end of Barrett Hill to the valley in the vicinity of Quinapoxet village. About 2 miles farther north a similar belt may be traced down the east slope of Stillwater Valley, $1 \frac{1}{4}$ miles below East Princeton, across the stream, up the west slope, and across the ridge to the large morainal filling in the valley of East Wachusett Brook.

The valley deposits that are considered terminal moraines consist very largely of sand and coarse gravel partly sorted and stratified and partly mixed with bouldery drift in a confused dump. The surficial configuration is one of knolls and ridges of gravel (kames) interspersed with irregular or bowl-like depressions (kettles, fig. 6), many of which contain small ponds and marshes. The difference in height between these humps and hollows ranges from 5 to not much more than 100 feet, so that their topographic expression is generally peculiar rather than imposing. These features are distinguished from kame terraces or morainal terraces (p. 47), which closely resemble them in surface form, in that the moraines generally 
filled the valleys from side to side, in places completely blocking them. Many of them are also distinguished by their relations to valley terraces of outwash gravels at whose head they stand (p. 56). They are differentiated from lacustrine deposits by the positions in which they occur and usually by their heterogeneous composition and pitted or otherwise uneven surface expression, indicating the presence of the ice in immediate connection with their deposition. The occurrence of these morainal features at intervals in the valleys indicates a succession of stages of more rapid melting or of less rapid forward movement of the ice, during which the glacial margin was melted back without halting sufficiently long to accumulate characteristic morainal deposits, alternating with stages of decrease in melting or increase in the forward movement of the ice, so that much débris was brought forward and left as the ice front oscillated back and forth across zones ranging from a fraction of a mile to several miles in width.

The terminal moraines are not only mostly confined to the valleys, but they are not generally heaped up in the shape of narrow transverse ridges such as form distinct morainal dams across valleys in
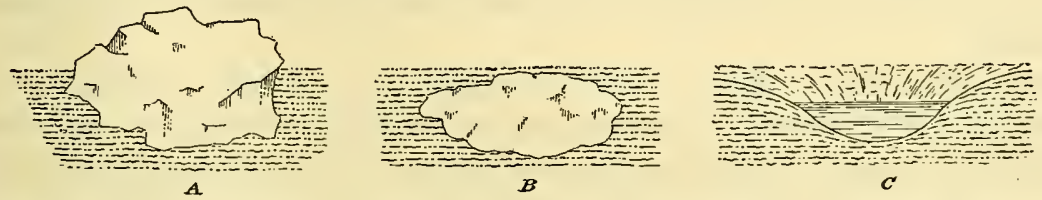

Figure 6.-Diagram showing probable origin of many kettleholes. $A$, Detached block of glacier ice; $B$, same block after part has been melted and the remainder covered wilh sand and gravel; $C$, depression resulting from complete melting of the ice. (After M. R. Campbell.)

many other glaciated regions. Instead, the drift is spread out along the valleys for distances of 1 mile to several miles, forming knolled and pitted tracts, in which the difference in altitude of the several parts is only that between the knolls and depressions.

TERMINAT MORAINES OF QUINSIGAMOND QUADRANGLE.

Notable examples of terminal-moraine deposits occupy the socalled "Auburn River" valley almost continuously from Worcester to the vicinity of North Oxford, a distance of 7 miles, and occur in Quinsigamond Valley both north and south of the lake and at numerous other places in the Quinsigamond quadrangle. (See Pl. VI.) Some of these deposits are described in connection with other features.

Masses of ice buried in the morainal débris appear to have remained intact for a long time after the disappearance of the glacier from their immediate vicinity. Otherwise the morainal drift in the 
open valleys would have been more cut by stream channels. This is especially true of the deposits in the head of Quinsigamond Valley southwest of Boylston Center, where but for the continuance of the buried ice masses intact as part of the drift dam, the water of the glacial lake in Nashua Valley would not have been held up to the level of the terraces formed while the waters were discharging through this outlet (p. 63).

TERMINAL MORAINES OF WARE QUADRANGLE.

Some of the best examples of terminal mornines in the Ware quadrangle are here noted. At the bend in the Quinebaug Valley west of Southbridge is a considerable mass of drift, which appears originally to have completely blocked the valley. An excavation for road material showed that the lower 10 to 15 feet of the 30 to 40 foot section is mostly unstratified sand and pebbly clay, crumpled and kneaded together, as if by forward crowding of the ice. Above this is bouldery till with streaks of stratified sand and clay kneaded into it.

A morainal ridge 80 to 100 feet in height, pitted with shallow sags, lies across the valley south of Quacumquasit Pond, north of Sturbridge.

Morainal drift forms the retaining dams at the south side of Little Alum Pond and on the southwest side of Alum Pond, continuing thence 3 miles up the valley in Brimfield Township. At South Spencer station and extending thence north to Spencer and east to Cranberry River is a considerable morainal deposit. Near the railroad kettleholes 10 to 30 feet deep pit the material, which consists principally of sand and gravel, as shown by a 30 -foot railroad cut and other exposures.

A morainal ridge with marked kames and abundant great boulders occurs near Tufts Brook, 3 miles south of Warren and West Warren.

South of South Monson a morainal fill completely blocks the valley for a distance of 3 miles, except for a narrow gorge cut in it by the stream. The full thickness of the drift is not known, but some of the hills rise 150 feet or more above the level of the stream. Cuts show the material to be sand, sandy till, and boulders.

About $1 \frac{1}{2}$ miles southeast of Palmer, at the electric-railway power house, the valley is abruptly narrowed by a ridge of drift, now cut through by the stream. Railway and wagon-road cuts expose 100 feet or more of loose gray sandy, bouldery till. A mile farther east the slope north of the railway rises 100 to 150 feet, to the crest of a narrow kame ridge, north of which is an area of strongly marked kames and kettles.

To the north up the valley toward Palmer Center is a flat partly eroded terrace of ontwash sand and gravel, which merges into an- 
other area of pronounced kames and kettles consisting of hills of sand and gravel interspersed with sags, in some of which are ponds. This is clearly a terminal moraine filling the valley, which is from half to three-quarters of a mile in width, from side to side, as far as the road leading northeast from the village. North of this road the surface lowers to a partly eroded terrace of sand and gravel, which was probably formed in a glacial lake held back of the moraine as the ice front retreated along the valley to the north. There was here a close association of lacustrine deposition and marginal glacial deposition, the material being principally sand with some gravel and including large boulders. The knolled and pitted character of the deposit shows that it was made immediately along the glacial front. In the valleys to the east are similar and probably contemporaneous moraines.

At the southwest end of Springfield Reservoir, northeast of Ludlow Center, is a considerable morainal fill. Excavations in the ridge which extends from this cut into the lake and on which are the filter beds show stratified sand and gravel dipping northeastward, indicating clearly that the detritus was washed in this direction from the east front of the glacier that occupied the Connecticut Valley, to the west.

Other morainal features occur in the valley extending southeastward from Coldbrook, north of the creek at South Barre, in the valley 2 miles north west of Hardwick, and at. Dudleyville in Leverett 'Township, where a narrow ridge marks the northwest boundary of a temporary glacial-lake basin.

The deposit extending for a distance of 4 miles along the Swift River valley above and below West Ware is probably a terminal moraine, as it has an uneven surface and nearly fills the narrow valley. It can scarcely have been formed as a kame terrace at the sides of a lobe of ice in the valley. The narrow inner valley traversed by the streams was undoubtedly excavated by the escaping glacial waters as the ice front was melted back toward the north and also by subsequent erosion.

KAME TERRACES,

ORIGIN.

Closely associated with the terminal moranes and usually merging into them are similar features lying along the side of the valleys but not extending across the full width. These are kame terraces or morainal terraces. They differ from ordinary stream terraces in several respects. The component material, which is glacial drift, is commonly coarse and bouldery and poorly assorted, and though mostly stratified, it generally shows disturbed stratification and may be partiy unstratified. The surfaces are not uniformly flat but have, 
especially along the margin toward the axis of the valley, the knolled and pitted configuration characteristic of moraines. The altitudes of such terraces on opposite sides of a valley do not usually correspond, as in lake or stream terraces, where the deposit is controlled by a common water level, and there may be variation in the gradients on the two sides, such as in lake or stream terraces might be taken as evidence of subsequent deformation.

After the ice had melted off the uplands for some miles to the north lobes of the glacier still remained in the valleys. The waters from the melting ice flowed down the slopes and ravines and washed more or less drift onto the margins of the valley lobes, where they lay against the rock slope (fig. 7, A). The waters thus gathered into considerable streams along this contact-here flowing over a bed of ice, there swinging against the valley slope-spreading out the

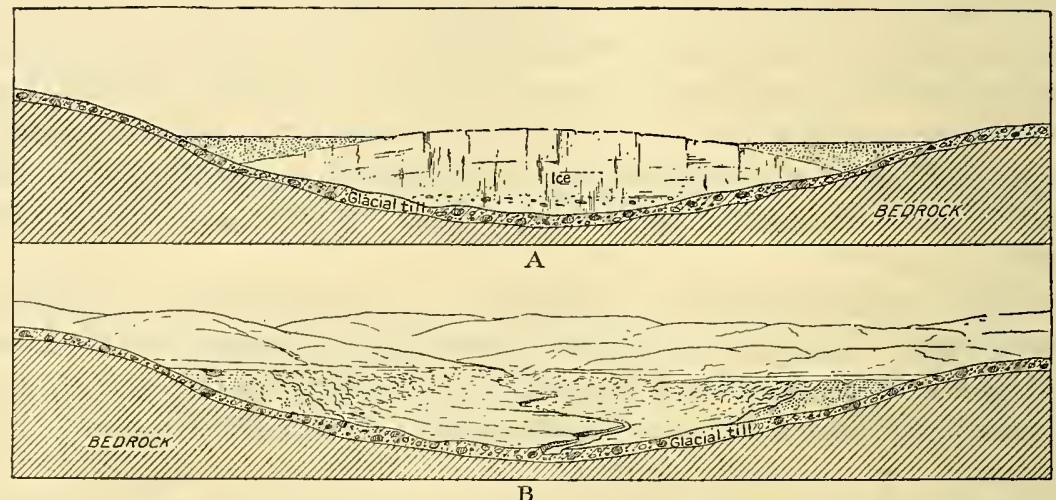

Figure 7.- Diagram illustrating formation of kame terraces. A, Terrace formed at the side of a melting glacial lobe in a valley; $B$, view up the valley after melting of ice has caused slumping of overlying material and formation of "ice-contact" slopes below the terraces.

sands and gravels and forming deposits a quarter of a mile to half a mile or more in width. At the south end of each ice lobe the stream deposits merge into the moraine, filling the valley from side to side. Here the melting ice left the drift piled in irregular knolls and ridges, except as spread out smoothly by the glacial waters. The sheet of débris lapped over the margin of the melting lobe, filling in crevasses and burying many ice blocks left detached by the melting. Through the spaces between the piles of drift and over the buried ice blocks the water escaped down the valley. Channels were cut, and meandering streams developed flood plains, leaving irregular remnants of moraines on either side. In time the buried ice masses melted, and as they did so the overlying drift settled and slumped down, leaving depressions (kettleholes) with abrupt gravel slopes. With the further wasting of the valley lobe 
the marginal stream deposits were left banked along the valley slopes (fig. 7, B). That part of the material resting on the rock maintained its form, except as included masses of ice left pits when they melted, but that part resting on the ice settled and slumped irregularly, developing the knolled and pitted surface to which is given the name "kame terrace" or " morainal terrace."

KAME TERRACES OF QUINSIGAMOND QUADRANGLE.

The largest kame terrace in the Quinsigamond quadrangle is that extending from Bolton Station, east of Clinton, northeastward along the east slope of the valley to Vaughn Hill. It probably originally continued as far south as "The Acre" and filled the gorge now occupied by Nashua River at Clinton. R'ailroad cuts northwest of Bolton Station and other excavations expose the stratified and cross-bedded sand and gravel composing the deposit. The undisturbed higher parts have flat terrace tops, which increase in altitude from about 380 feet above sea level at Bolton Station to 400 feet at the Bolton Industrial School, sonthwest of Vaughn Hill. 'Toward the river the surface has a steep slope, much lobed and irregular, as a result of the slumping when the retaining wall of ice melted away, and dissected more or less by subsequent erosion. This terrace as seen from the west is a marked topographic feature 100 to 150 feet above the valley floor, with the wall of the valley rising above it on the east. The gravel composing the terrace was deposited in a trough between the upper east slope of the valley and the sloping surface of the ice, which was at that time so far reduced that it lay as a lobe only about 3 miles in width, extending several miles beyond the main front of the glacier down the valley to the vicinity of Clinton. The lake occupying Nashua Valley at that time discharged through the south-dike outlet to the Assabet basin, and the marginal stream forming the terrace doubtless poured much of its gravel-bearing water through the cols and down the valleys converging at West Berlin.

About $3 \frac{1}{2}$ miles southwest of Clinton a much smaller marginal deposit merges into a flat terrace or delta at an altitude of 480 feet above sea level. Apparently this deposit was formed where the marginal stream discharged into the open lake at the ice front when the outlet was southward through Quinsigamond Valley. So also on the north side of Fort Meadow Reservoir, 2 miles south of Hudson, a pitted deposit on the lower slope merges at the west into a finely developed terrace or delta where a stream at the side of a small ice lobe in the valley dropped its burden in the ponded waters. An excavation in the abrupt marginal shope showed stratified gravels dipping to the west at an angle of $30^{\circ}$. 
KAME TERRACES OF WARE QUADRANGLE.

Bordering the lower valley slopes south of Brookfield and East Brookfield and converging thence southward to the moraine at the head of Quacumquasit Pond are kame deposits, evidently formed along the lateral margins of an ice lobe that lay in the valley.

Similar deposits bordering the east side of the valley at Warren were probably formed as a terrace as the ice front lay along the foot of the slope.

When the uplands to the east were largely freed from ice a lobe still extended southward in the broad valley of the Connecticut. Where the margin of this lobe lay along the rocky slopes rising on the east there was good opportunity for the formation of glacial features of this class. The best-developed kame terrace is near the State line, extending southward from Scantic into the town of Somers, Conn. Here fully 90 per cent of the drift is composed of fragments of red sandstone and conglomerate from the Triassic beds of the great valley. Farther north, near North Wilbraham and Ludlow. Center, in the town of Granby, and near Dwight, similar terraces were also formed successively as the ice was melted slowly back across the upland while yet projecting farther southward in the valley.

ESKERS AND GLACIAL STREAM CHANNELS.

ESKERS OF QUINSIGAMOND QUADRANGLE.

There are within the Quinsigamond quadrangle about half a dozen small eskers a mile or more each in length and a few shorter fragments. The origin of these features is discussed below (p. 54), and their locations are shown upon the map. One of the best examples occurs at Hadwen Park, in the southern part of Worcester. This appears as a narrow ridge on the south bank of the stream, whence it extends southward in a sinuous course entirely through the park. Near the park shelter it is 30 feet high, with narrow crest and sides sloping down at angles of $30^{\circ}$ to $35^{\circ}$. At one point it swings in an oxbow curve close to the hill slope on the west and then away from it, as if this slope had deflected the esker-forming stream. Cuts at the south line of the park at Clover and Webster streets show the ridge to be composed of unsorted fine to coarse gravel, in which the largest stones are $1 \frac{1}{2}$ feet in length. An examination of 100 pebbles taken at random from one of the cuts showed 57 to be of Worcester phyllite, 25 of granite, 8 dense greenish schist, 7 gneiss, and 3 quartz. Between Webster and Boyce streets the ridge has mostly been cut away by erosion, but east of Boyce Street it continues with slight relief eastward and then southward about half a mile, merging with the sags and swells of the morainal topography. 
About $4 \frac{1}{2}$ miles farther east, near the south end of Lake Quinsigamond, just east of the corner of Lake Avenue and Harrington Street, is a narrow sinuous gravel ridge that extends south to the electric railway on Grafton Street and thence through the woods to the head of Dorothy Pond. In some places this ridge is 30 to 40 feet high; in others it spreads out indefinitely, blending with the swells of the morainal topography.

About $3 \frac{1}{2}$ miles northeast of North Grafton a sinuous ridge of gravel runs southward from the electric railway 450 to 550 yards and then branches into three distinct ridges 10 to 30 feet in height, which continue south about half a mile and merge into the morainal deposit at the head of Miscoe Brook valley. The easternmost of these ridges $\mathrm{swings}$ across the north-south road and extends up a slope 20 to 30 feet in height onto the south end of the morainal ridge east of the road.

About $2 \frac{1}{2}$ miles still farther east, another system of eskers extends from the southern part of Westboro to Westbor o Reservoir.

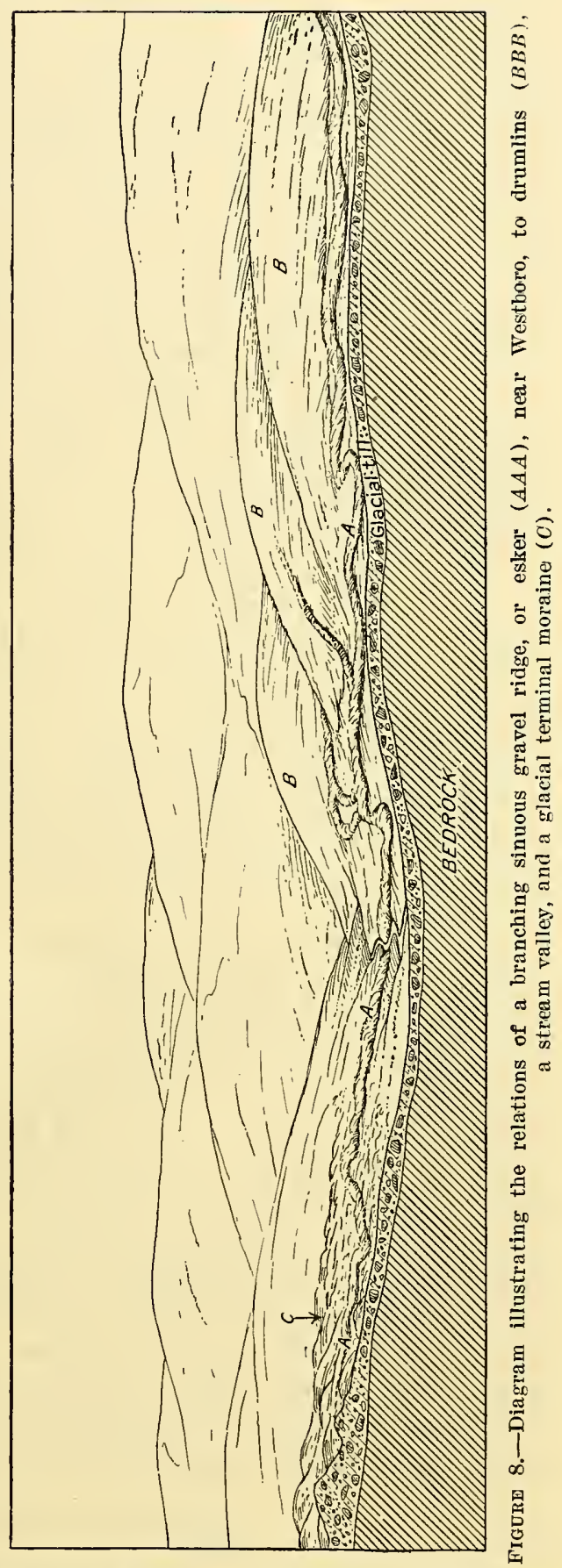

Here there is an interesting association of eskers with drumlins (fig. 8). The foot of the east slope of the finely formed drumlin iust south 
of Westboro is closely followed by a sharp, narrow esker ridge of gravel. The road passes through a narrow break in this ridge, and east of the road the ridge continues south about 1,000 feet. At this point it is joined by a similar ridge, which comes from the northwest directly down the lee (sontheast) slope of the second drumlin of the group and crosses the road. A third branch heads between the second and third drumlins and joins the other's east of the road. These ridges are in places 30 feet high, and cuts show them to be composed of fine and coarse gravel and small boulders. A fourth lranch or loop of the system is traversed for 300 yards by the eastwest road and joins the others at two points. For 300 yards east of the bend in the road the trunk esker lies along the slope. Then it swings to the south across the valley. Here it evidently formed a dam, holding the lakelet in the basin to the west until erosion cut an outlet through the ridge. South of the creek the esker climbs the slope to a height of 70 to 80 feet, then shifting a little it runs along the slope, is cut through by a creek, and finally merges into a terminal moraine surrounding Westboro Reservoir. To reach this moraine the esker makes an ascent of about 100 feet in three-quarters of a mile, and 80 feet of the ascent is accomplished in less than 450 yards. There are two small eskers about $1 \frac{1}{2}$ miles southwest of Hopkinton, in a shallow valley. One of them is traversed by the north-south road throughout its length of three-quarters of a mile. These esker's end within 450 yards of a small morainal deposit that occupies a sag between two hills.

Between 3 and 4 miles southwest of Uxbridge two eskers, each about a mile in length, lie beside brooks and near and parallel to ridge slopes and terminate in a broad gravel deposit that is partly flat and partly knolled and pitted like a marginal moraine.

About a mile west of Gates Crossing, in Leominster Township, is a finely formed esker 15 to 35 feet in height and 1 mile in length, which divides the small reservoir and runs thence south to the col between Fall and Wekepeke brooks. Here it spreads out along the lower east slope and ends indefinitely. Three-quarters of a mile to the south is the well-developed terminal moraine surrounding the Clinton Reservoir. Small eskers border the brook in the valley above East Princeton and north of Brigham Pond, in Hubbardston, and others occur at several places associated with moraines. The eskers in Nashua Valley south of Clinton described by Crosby are now mostly submerged by the Wachusett Reservoir (Pl. XII, $B$ ).

ESKERS OF WARE QUADRANGLE.

Eskers are rare within the Ware quadrangle. The few small examples that have been observed are described in the order of their 
development as the ice front retreated-that is, from southeast to northwest across the area.

The south end of Hamilton Reservoir, in the town of Holland, is divided by a sinuous gravel ridge, which extends southeast ward half a mile and merges with a pitted frontal terrace of gravel.

At 3 miles southeast of Wales a similar small esker merges with a small terrace near the State line.

Near the west side of the ponds half a mile northeast of Sturbridge a small sinuous gravel ridge, followed for half a mile by the road, marks the position of a stream of glacial water emerging from its ice channel at the moraine upon which the village stands.

A small esker emerges from the little road pond south of the Quacumquasit Pond moraine and extends thence about a mile southward to the north end of Cedar Pond, where it merges into outwash gravel. Cuts at the north end of this esker exposed fine brown angular arkose gravel resembling coarse sawdust. At the south end, near Cedar Pond, the material, is coarse morainal gravel.

In Monson Valley there is a deposit probably formed, at least in part, as an esker by glacial streams that flowed southward in the ice in the valley and probably discharged at the glacial front as it stood at the moraine at South Monson. Near the old mill at North Monson the ridge of sandy drift stands 100 feet above the country on the east. From the crest it spreads out to the west across the electric railway to the rocky slope like an uneven terrace. Cut through by the creek at the old mill, the ridge crest reappears on the east side of the stream, between the wagon road and the railroad, and extends thence southward $1 \frac{1}{4}$ miles. Beyond this for half a mile it appears to have been largely removed by erosion. A section of the narrow ridge near the mill pond at South Monson, where the esker-forming stream must have reached the moraine, shows 20 feet of bouldery till overlying 20 feet of stratified sand, the bedding of which dips southward, in the direction of the flow. At the north side of the cut there is an appearance of crumpling, as if due to crowding of the ice when the till was dumped on top of the esker sands. When first formed this may have been a well-marked, definite esker through its full length, but with the further melting of the ice the deposition of terrace gravels along the valley sides rendered the esker less distinct.

In the valley just west of the junction of Beaver Brook with Ware River an esker ridge forms the margin of the terrace. A mile to the south this ridge flattens out to a pitted terrace, and this in turn to a fine flat terrace just north of the railroad. This terrace is evidently a delta deposit formed by the discharge of the esker stream into a lake at the ice front. 
Two miles north of the railway bridge at Bondville a small esker about half a mile in length is associated with the kame deposits west of Swift River.

\section{ORIGIN OF ESKERS.}

All the eskers of this area are composed of a mixture of waterworn rock fragments of varied lithologic character such as constitute other parts of the water-laid glacial drift of the region. These fragments range from grains of sand to boulders $1 \frac{1}{2}$ feet in length. The material, though waterworn, is not usually stratified in undisturbed layers. The deposits follow narrow, sinuous, and sometimes branching courses like channels of streams, but the gravel instead of lying in channels is heaped up in sharp, narrow ridges, many of them 30 to 35 feet high, and with slopes about as steep as the gravel will lie. These eskers are believed to be the result of the deposition of gravel by streams of glacial water flowing in channels or tunnels in the ice, the melting of whose walls allowed slumping of the gravel into the form of ridges. Their location, usually in valleys, cols, or hasins, in the drift near and parallel with the axes of the depressions, leads to the inference that the streams were sufficiently near the base of the ice for their courses to be controlled by the topography beneath the ice, and most of them were within less than 50 feet of the base. In such places as the channel in the drumlin crest at Gleasondale (p. 55) the stream must at first have been at least 100 feet above the base of the ice north of the hill. The same must be true of the stream forming the esker which makes an ascent of 100 feet to reach the moraine at the Westboro Reservoir (fig. 8), unless the water was forced up the slope in a rising tunnel under hydrostatic pressure, and to furnish this pressure the stream must have had an even higher level nearer its head. The drumlin on whose lee slope one of the branches of this system of eskers begins rises about 100 feet higher than the moraine at which the esker ends. This crest is not channeled, and the esker is traceable only down the lower slope from a point about on a level with the terminus at the moraine, so that it is not known what was the original level of the channel in the ice. The ending of most of the eskers in or near terminal-moraine deposits or their merging into sand plains formed in ponded waters shows that they were formed at positions of halt of the ice front during the general progress of final deglaciation of the area. As the margin of the ice was undoubtedly thinned by melting, a frontal slope probably rose gradually from the terminal moraine and bordering lakes, and the streams that formed the eskers, but few of which are more than a mile in length, may have flowed down this frontal slope, the deposition of gravel in the channels taking place only where the streams crossed the exposed edges of the drift-bearing layers of the lower 100 feet or so of the ice. 
GLACIAL STREAM CHANNELS.

At several places within the area hilltops are cut by eroded channels, which must have been developed when the relations of the drainage from the melting glacier were such that streams were held by the ice in positions to flow over what are now the tops of hills. One of the most interesting of these channels is at Gleasondale, in the township of Hudson. This channel, with others of similar character, has been described by Barton. ${ }^{15}$ North of the railroad is a double drumlin known as Orchard Hill, which rises 100 feet above Assabet River. One ascending the abrupt east slope is surprised to find the east crest cut longitudinally by a narrow, slightly sinuous channel having a maximum depth of 27 feet. The channel begins about 75 feet above the base of the north slope, and except for a few feet at this end, due probably to recent deepening, the bottom has a continuous southward slope. There are three sags in the bottom between which the depression is slightly shallower. Near the south end of the channel a small elongated knoll occurs in the sag, appearing like the beginning of an esker. Beyond a short interval a small eskerlike gravel ridge about 5 feet high continues down the sag to the street, beyond which is a gravel terrace spread out like an esker delta formed in a glacial lake. A little brook issues from the sag beside the ridge, and erosion has deepened the depression along this drainage line. The relations here show that at the time of the erosion of this channel the ice enveloped Orchard Hill and a stream was flowing in a tunnel or channel in the ice about 100 feet above the base. This stream in cutting down its ice channel encountered the crest of the hill and there began the excavation of the channel in the drift, which it continued down the south slope. The gradient was so high that the channel was swept clear of débris, except on the lower slope, where erosion ceased and gravel began to be deposited. It is not perfectly clear that the partly eroded gravel terrace extending to the abrupt marginal slope south of the electric railway is a delta formed by this glacial stream, though it appears to be. As discussed below (p. 74), the terraces of the Assabet Valley show that a glacial lake occupied the basin as the ice front gradually withdrew from it, and just prior to the opening of the present channel at Rockbottom the col traver'sed by the railroads west of Gleasondale formed a channel connecting the lake on the west with one on the east. The flat terrace on which is the highest part of the village stands about 230 feet above the sea, somewhat higher than most of the gravel deposits of the vicinity. This terrace was clearly formed in the body of water,

\footnotetext{
${ }^{15}$ Barton, G. II., Glacial origin of channels on drumlins : Geol. Soc. America Bull,, vol. 6 , pp. 8-13, 1895 .
}

$92817^{\circ}-24-4$ 
and its character, altitude, and location directly opposite the channel cut in the drumlin crest and merging into the slight esker heading in this channel are most readily explained by regarding it as a delta formed where the stream of glacial water debouched from its channel of drift and ice into the lake at the glacial front.

\section{STREAM TERRACES.}

TOCATION.

Certain terraces in this area were at least in part the product of the glacial waters after they had left the immediate vicinity of the ice front. In the smaller valleys in the southern half of the area, most of which drained southward, are deposits of sand and gravel which in some places head in pitted morainal tracts and in others have no definite connection with such tracts. As the ice front retreated up the valleys, here and there the drainage was so blocked by earlier deposits that waters were ponded and fine laminated sand and sandy clay were deposited, sometimes with included berg-dropped boulders. Near the exposed silts or overlying them are coarse gravels and boulders. These terraces, as is well illustrated in the valleys of West River, Warren Brook, and Center Brook, above and below Upton, are thus composites, and the surface configuration is partly of sag and swell type and partly flat and terrace-like. After dropping their load the waters proceeded to erode the deposit farther down the valley, so that it is now cut through by a flat-bottomed channel of varying width through which the present streamlets meander.

Blackstone Valley became an important line of glacial drainage as soon as the retreating ice front permitted. In consequence, from the vicinity of Ironstone northward to its junction with Quinsigamond River, near Fisherville, the stream is bordered by terraces. From Ironstone to Goods Hill, 2 miles north of Uxbridge, there is one well-developed terrace about 30 feet above the broad flood plain that borders the stream (Pl. XV), and remnants of another appear still higher. Above Goods Hill there is no terrace corresponding to the highest farther south. The upper terrace here is the same as the second from the top to the south. The latter terrace is broad and well marked. Above Fisherville and Saundersville the definite terrace form disappears and the gravel merges into morainal deposits. The material composing the terraces is principally stratified sand and fine to 3-inch gravel. In places boulders occur embedded in the deposit, and they are generally plentiful on the surface.

From the character of these features it appears that they are essentially the same as those of the West River valley, but they have suftered greater modification by erosion. The remnants of the upper 
terrace below Uxbridge have the pitted and uneven surface of morainal deposits or kame terraces. The second terrace developed by erosion of the upper has a broad, flat top and is a typical abandoned flood plain. Before the water had entirely cut away the upper terrace it began to cut into the second terrace and developed the present flood plain, 25 to 30 feet below. Above Uxbridge the terrace is flat and in places more than half a mile in width.

ORIGIN.

The conditions of development of such terraces are illustrated in Figure 9. During the retreat of the ice front along the valley from Woonsocket to the vicinity of Uxbridge morainal and kame terraces were formed. The water after depositing its load began to cut farther down the valley, and as the ice continued to retreat northward the flood plain (now the second terrace) was extended to Uxbridge. Above Uxbridge the waters spread out the gravel of the upper terrace, while they were eroding farther south. 'This process continued northward to the junction of the Blackstone and Quinsigamond valleys, the work of erosion lagging behind that of deposition. As the retreat continued the divergence of tributary valleys brought in waters from a greater extent of the glacial front and augmented the eroding. power, while the deepening of the lower valley increased the gradient and led in turn to a partial erosion

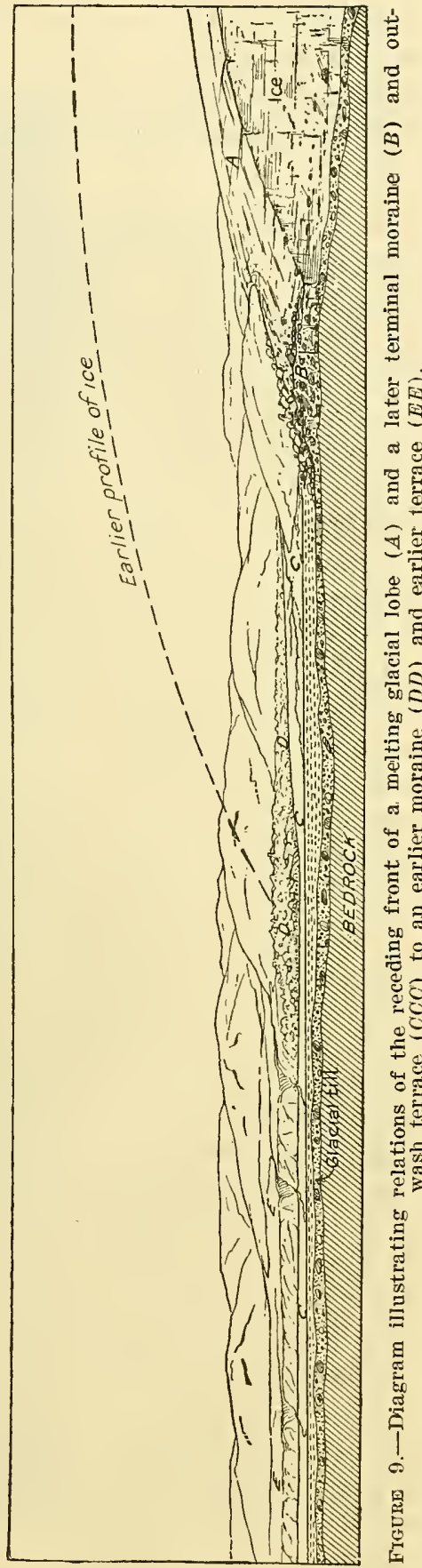
of the second terrace. The discharge of the glacial waters down Quinsigamond Valley continued until the opening of the south-dike 
outlet for the lake in Nashua Valley, so that the lower terrace, or present flood plain, was extended north to Fisherville. Above this point it is less well defined, though the channel extends northward to Lake Quinsigamond.

\section{BOULDERS.}

On the final melting of the ice boulders were left so abundantly scattered over the surface of the drift that they must have added greatly to the difficulties experienced by the early colonists in clearing their land for cultivation. Their industry, supplemented by that of succeeding generations, however, has gathered most of these into the walls by which the fields are inclosed (Pl. XVI, $A$ ). In some places the boulders are not only very numerous but so large as not to be readily moved (Pl. XVI, $B$ ). In the Ware quadrangle such big boulders occur just west of Palmer, 2 miles east of New Braintree,

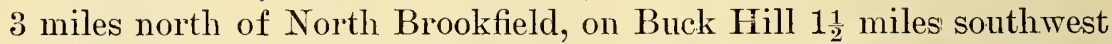
of North Brookfield, 2 miles west of Brookfield, 1 mile southwest of South Spencer, and just north of Sturbridge. The boulders are not distributed in definite belts but are scattered indiscriminately. At these places they consist largely of very coarse granite and are not uncommonly 10 to 15 feet in diameter. Schist, which splits up more readily than granite, usually constitutes the smaller boulders. In the lee of the exposures of the very coarse Coys Hill granite, notably large boulders of this rock occur. These are especially abundant at points 2 and 3 miles south of West Warren, where one boulder of coarse granite gneiss beside the road on a northwest slope measured 15 feet in height and 90 feet in circumference. North of Ridge Hill, 3 miles in a direction south by east from Dana, large boulders are very abundant upon a small morainal deposit. In a marshy depression back of Charles Griffin's house is one of the largest boulders seen in this region. This rock, which is a coarse pegmatite, is about 18 feet high, 12 to 15 feet thick, and 45 to 50 feet long. A large block is split off one end and tipped over 1 to 3 feet from the main mass, and in this space a good-sized tree is growing. A very large boulder also occurs in the valley half a mile north of Barre post office. One of the finest examples occurs at a point $1 \frac{1}{2}$ miles north of Gilbertville, on the ridge 650 feet west of George P. Manly's house (Pl. XVII, $A$ ). Perched upon the crest of the ridge at this place is a boulder of coarse granite 89 feet in circumference, with diameters of 29 and 31 feet, and a tape line drawn over the top from ground to ground measured 49 feet. Split off one end of this boulder is a mass 53 feet in circumference, with a maximum thickness of 7 to 8 feet.

Some of the large boulders were left by the melting of the ice perched in what, but for their great masses, would be very insecure 


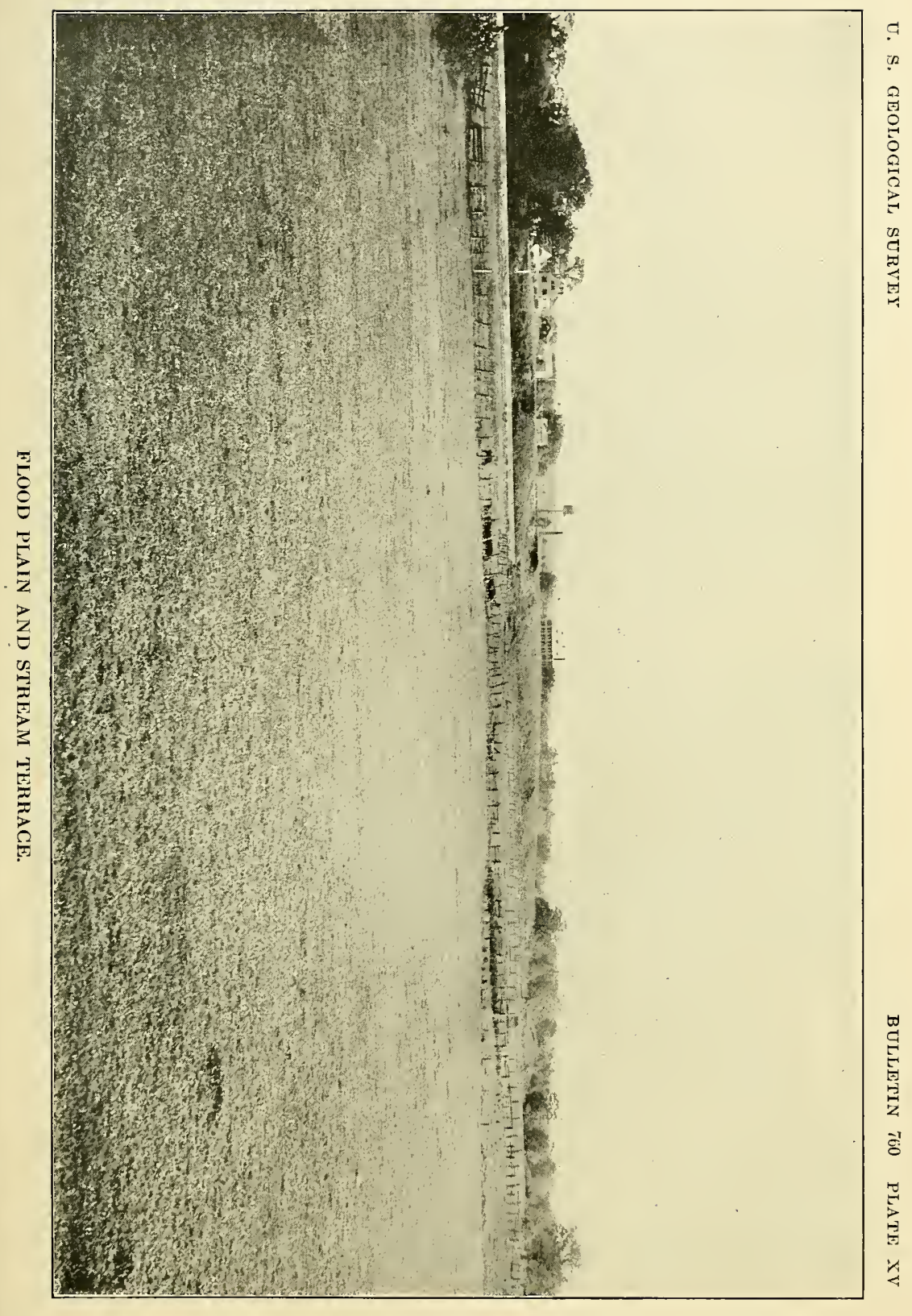




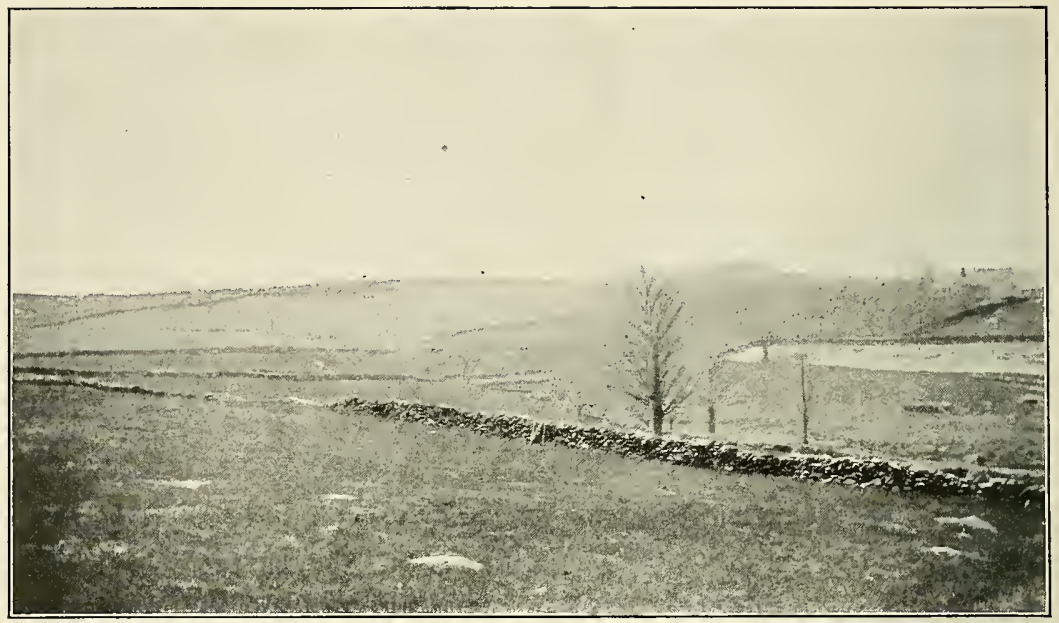

A. WALLS OF GLACIAL BOULDERS INCLOSING FARM LANDS NEAR DANA, MASS.

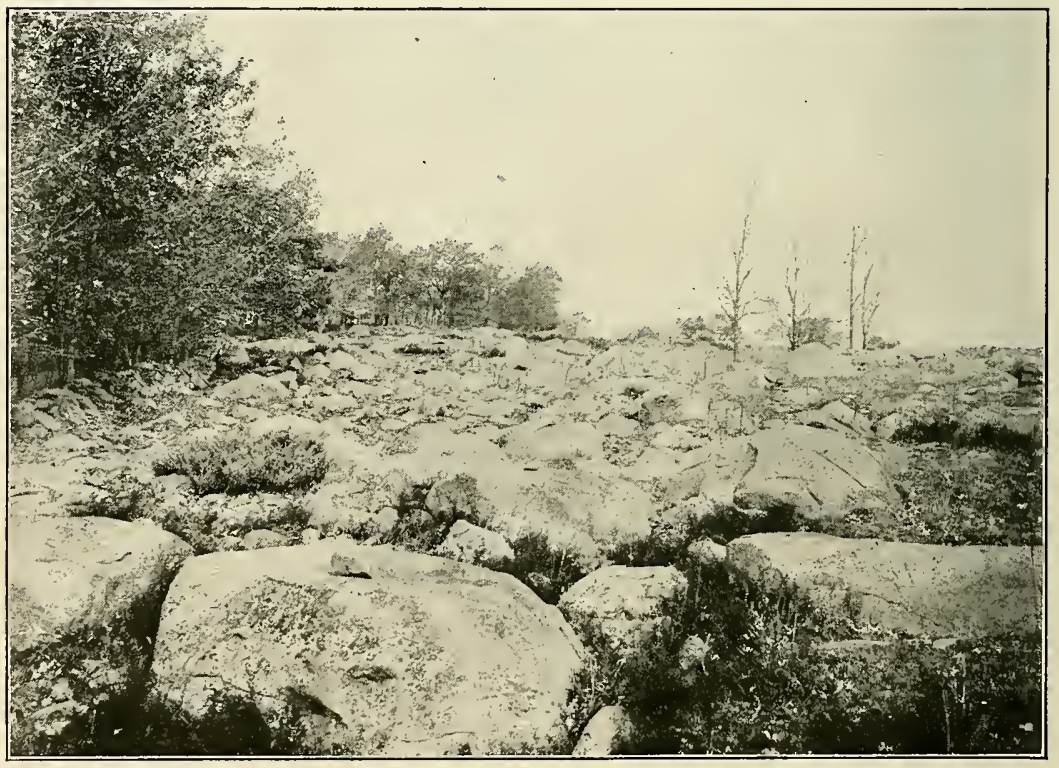

B. Glacial boulders near pRInceton Center, mass. 


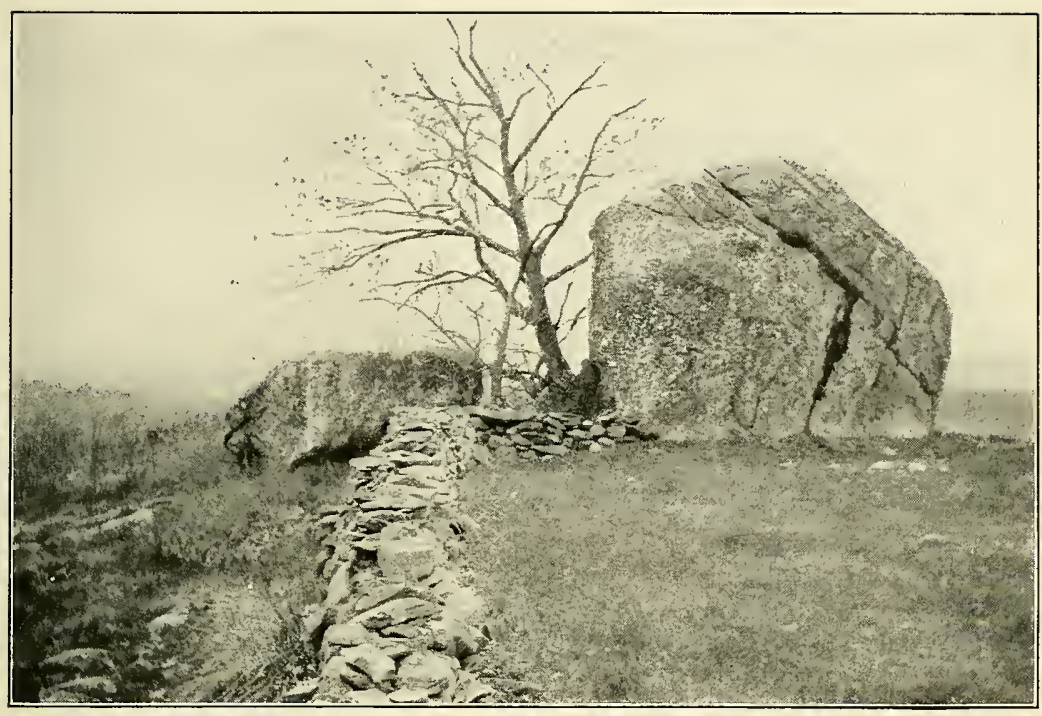

A. GLACIAL BOULDER NORTH OF GILBERTVILLE, MASS.

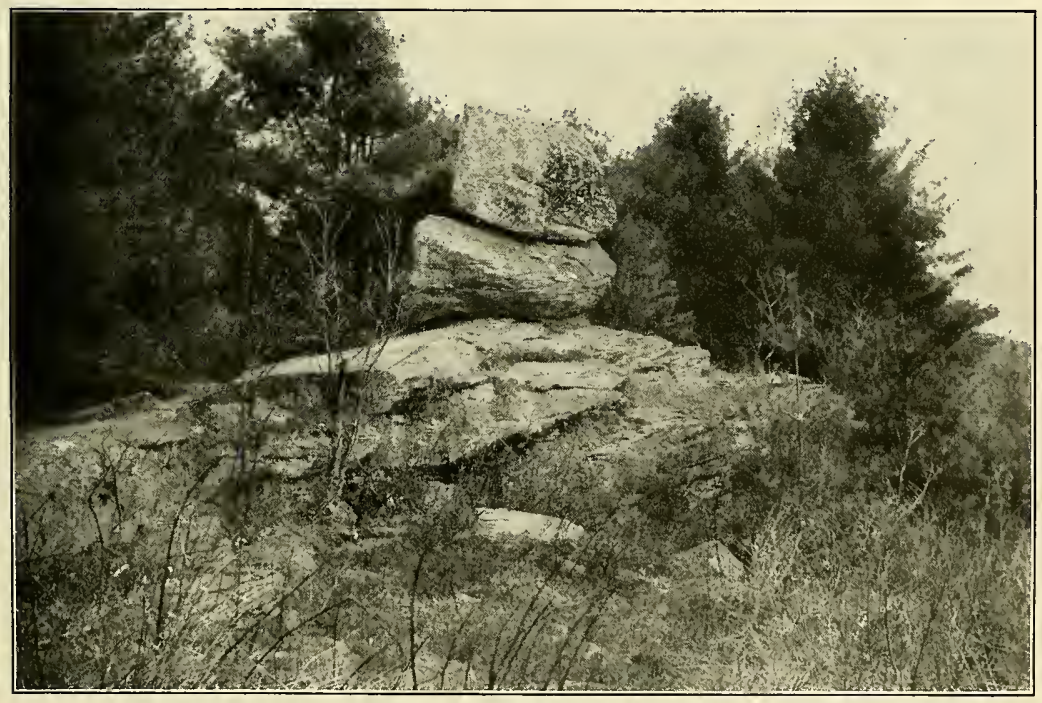

B. PERCHED BOULDERS 3 MILES NORTHWEST OF BARRE, MASS. 

positions. One such boulder, locally known as the "rocking stone" and pictured by Edward Hitchcock, ${ }^{16}$ is a very curious example of one boulder perched upon another (Pl. XVII, B). It occurs on H. L. Harris's land, 3 miles northwest of Barre, near the road to Dana. The upper block, 5 by 8 by 8 feet in size, is of coarse granite and rests on a block of granite gneiss $4 \frac{1}{2}$ by 8 by 10 feet, and this in turn on the rounded surface of a ledge of granite. It is strange indeed that the melting of the inclosing ice should let down the one block upon the other in a position so precisely balanced that it has so remained through all the succeeding centuries.

Hitcheock ${ }^{17}$ also mentions a boulder in Berlin that was said to weigh 160 tons and yet could be moved by a boy 6 years old. Another in Berlin, 1 mile east of the meeting house, on the road to Bolton, was described to him as " a boulder of granite 17 feet long and 27 feet in circumference, resting upon granite or gneiss, apparently just ready to fall, and yet five men with levers were unable to throw it from its base."

\section{EXTINCT GLACIAL LAKES.}

\section{CHANGES IN ELEVATION OF THE LAND.}

Geologists have collected numerous data tending to show (1) that the northeastern part of North America, including much of New England, was depressed under the weight of the vast accumulation of ice that formed the great ice sheets; (2) that, as the ice melted and the glacial margin receded northward, marine waters spread over the lower parts of the depressed land; and (3) that after the land was relieved of the weight by the melting of the glaciers it rose again, in somewhat the same manner that a rubber ball in which the pressure of a thumb has made an indentation in one side regains its spherical form after removal of the pressure. Whatever the cause may be, it is clear that there was depression and reelevation near the end of the glacial epoch. The amount of such reelevation increased gradually northward from practically nothing in southern New England to 500 or 700 feet in the northern parts of Vermont, New Hampshire, and Maine and to 1,000 feet in the region between St. Lawrence River and James Bay. The degree to which the part of Massachusetts under discussion shared in the depression and subsequent reelevation is not certainly known. It has been claimed that tidal waters extended far up the Connecticut River valley; that estuaries headed well within the area here described, one in the Nashua Valley and another in the Blackstone Valley; and that the east coast of Massachusetts was then in the longitude of

${ }^{16}$ Final repor't on the geology of Massachusetts, vol, 2, p. 376, 1841.

${ }^{17}$ Idem, p. 375. 
Marlboro, with an embayment in the Assabet River basin. It may be stated, however, without discussing the subject fully, that the evidence presented for so extensive a postglacial submergence of eastern Massachusetts is regarded by many geologists 'as "insufficient to support the conclusions drawn. So far as the deposits found in the Ware and Quinsigamond quadrangles are concerned, it seems to the writer that adequate explanation of their character and mode of occurrence is to be found in the relations of the receding ice front to the configuration of the land. These relations eviadently must have been such as to result in the formation of many temporary bodies of fresh standing water, in which lacustrine deposits would be laid down at various levels conforming to those of the a vailable outlets.

Waters escaping from a melting glacier produce a variety of land forms, determined by the presence or absence of open channels that permit flowage directly away from the vicinity of the ice front.

In the valleys draining northward or northeastward the retreat of the ice front as the glacier melted freed the southern parts of the basins from ice while yet the old outlets were blocked, thus causing the formation of temporary lakes at the glacial front, and in these lakes were formed glacio-lacustrine deposits. When the basins were wholly freed of ice the lakes were drained, and the deposits were thus exposed to erosion by the streams. The most notable of these temporary lakes in the Quinsigamond quadrangle were those occupying the Nashua and Assabet river basins, which have, for convenience, been designated glacial Lake Nashua and glacial Lake Assabet. The relations of these lakes to the ice front are illustrated in Figures 10 and 11 and Plate XVIII.

GLACIAL LAKE NASHUA.

DEPOSIT OF THE PRELIMINARY OR QUINAPOXET STAGE.

The freeing of the Nashua River basin from ice began in the town of Holden (see map, Pl. VI), and here in the valleys of the Quinapoxet and its southern tributaries are found the initial deposits to be correlated with the history of glacial Lake Nashua. The cols at the heads of the southern tributaries served as the initial outlets for the glacial waters. One of the first of these ontlets to be used was the col above Holden Reservoir, at the head of Tatnuck Brook. This has an altitude of about 820 feet above sea level. Another was the col traversed by the railroad at Holden, at an altitude of 760 feet. This leads to the col south of Chaffin Pond, at about the same altitude. Both led waters from the lake to the Blackstone Valley at Worcester. The drift surrounding the drumlins at Jefierson and Eagleville and occupying the valley north and west of Chaffin Pond consists very largely of stratified sand and gravel, but here and there 
much coarser material and boulders are intermingled with the fine deposits, and the surface aspect is that of a terminal moraine. Evidently the material was deposited in immediate connection with the ice fiont, so that many ice blocks were buried in it, and the melting of these ice blocks produced the pitted topography. From the south side of Chaffin Pond a small flat covered with sand and gravel leads to the col. On the northeast slope of Davis Hill, west of Unionville. are two flat sand and.gravel terraces with abrupt margins toward the valley. 'The upper one, which is a quarter' of a mile in width, lias an altitude of 720 feet above sea level (by barometer). These terraces were apparently formed in ponded waters after the ice had withdrawn slightly from the slope of Davis Hill. They are lower than the col south of Chaffin Pond, and may mark positions of the water when it was beginning to escape about the north slope of Malden Hill to the cols north of Summit Station.

West of the north end of Malden Hill there is a notable filling of sand and gravel in the valley, through which the Quinapoxet has cut a sharp narrow channel 100 to 140 feet in depth. Above this drift dam the valley bottom is flat and nearly half a mile in width. This deposit has a very even horizontal crest line at an altitude of about 600 feet above the sea, except where a few knolls rise above the general level. Close examination shows it to be pitted with kettles and cut by erosion. The upper surface corresponds with that of a flat gravel terrace about one-eighth of a mile in width on the north side of the stream, and the relations indicate that the two were originally continuous, the valley being completely blocked up to this level. The material of the terrace is apparently a marginal glacial deposit formed in ponded waters. At a corresponding level is a slight beachlike ridge of gravel near the house on the north slope of Malden Hill. An outlet that would determine the level of the lake at 600 feet above the sea is not found west of that at the head of the short east branch of Gates Brook, $1 \frac{1}{2}$ miles south of Boylston Common. The lacustrine deposits east of this drift dam are at lower levels, so that it would seem that while this filling was being made the ice must have occupied the valley to the east, its margin extending southeastward along the slope to the col just west of that traversed by the Boston \& Maine Railroad, but it blocked any egress through the col at Quinsigamond Valley, southwest of Boylston Center. From the col sontheast of Boylston Common gravel extends down the valley of Great Brook to the Quinsigamond Valley.

DEPOSITS OF THE BOYLSTON STAGE.

In Nashua Valley below Oakdale terraces occur at intervals along the south side 160 to 180 feet above what was the stream chamel before the submergence resulting from the construction of Wachu- 
sett Reservoir. These terraces are about 480 feet above sea level, a position which corresponds with the flat tops of the higher parts of the deposits in the col southwest of Boylston Center, whence it appears that at the time of the formation of these high terraces this part of Nashua Valley was at least partly free from ice and was occupied by a lake discharging through the Boylston outlet over the morainal drift and buried masses of ice and down Quinsigamond Valley (fig. 10, $A$ ). From the relations of the deposits to the several villages in the town of Boylston Crosby applied the name Boylston to this stage of the lake. The maximum extent of the lake at this stage is shown on the map of the Quinsigamond quadrangle (Pl. VI). Deposits of sand and gravel, considerably pitted and eroded, extend eastward from the drift dam in Quinapoxet Valley described above (p. 61) to Oakdale, where the cemetery and upper part of the village are located on a flat terrace at 460 to 480 feet. On the south side, next the stream, the structure of the deposit is partly exposed in an abrupt 60 to 80 foot erosion slope. The material is largely sand, with some gravel, stratifield as in the topset and foreset beds of a delta. The beds dip east, showing that the sand and gravel were washed into the lake from the west, and it is probable that they were derived from the erosion of the drift dam described above, after the water had lowered to the Boylston stage.

From the Industrial School eastward to West Boylston stratified sand and gravel occur in low swells along the north slope of the valley up to about 480 feet above sea level (fig. 11). East of the electric railway these deposits merge with a moraine and an esker, which extend north through the col to Stillwater River. No deposits of this stage were noted about the south and east slopes of French Hill. Southeast from Boylston Common to Muddy Brook, above the 400-foot level of the Clinton terrace, a deposit of sand and gravel about half a mile in width rises to a nearly uniform height of 480 to 490 feet against the higher slope. The surface is more or less uneven and shows numerous kettleholes. The deposit was probably formed as a terrace between the valley slope and the ice front as it began to withdraw from the moraine in the col southwest of Boylston Center. There is no indication that it originally extended northward entirely across the valley, though it may have had a somewhat greater extent than now, especially where is now the submerged valley of Muddy Brook. Sand and gravel extend northeastward from the outlet along the east side of the valley. At West Boylston the cemetery stands upon a finely developed terrace at 480 feet. The material exposed in the upper 100 feet of the abrupt erosion slope-that part above the water level at the time of the writer's visit-is principally sand, with some fine gravel and a little fine 
PHYSICAL FEATURES OF CENTRAL MASSACHUSETTS.

laminated sandy clay, stratified in layers dipping toward the axis of the basin.

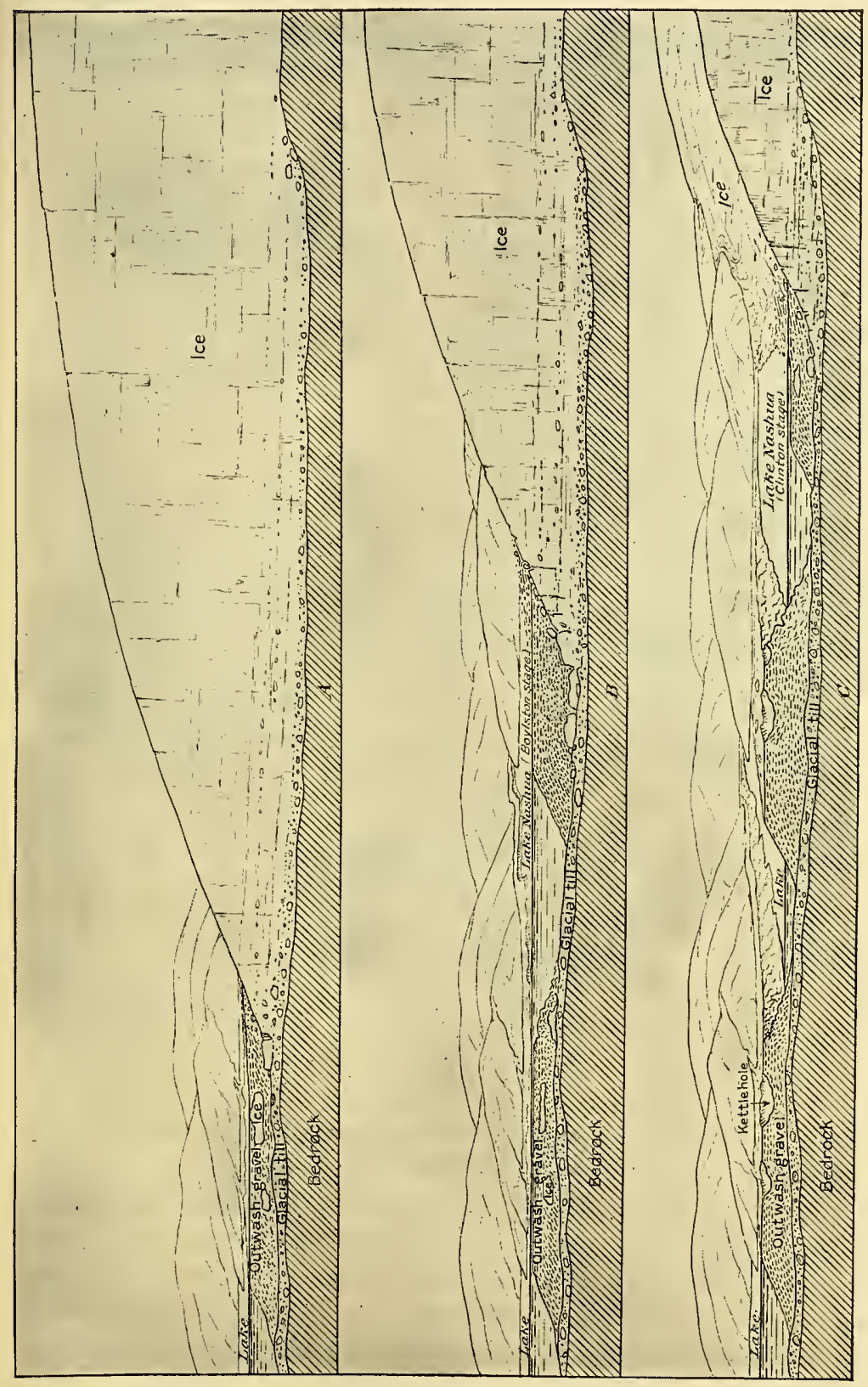

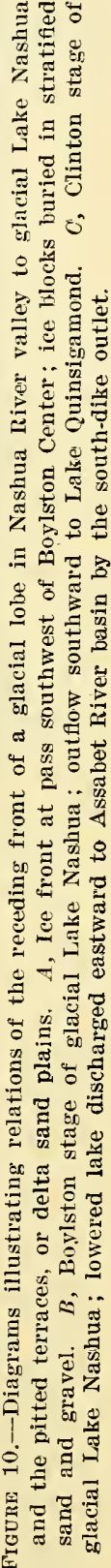

Between 1 and $2 \frac{1}{2}$ miles northeast of Boylston Center broad remnants of terraces of the Boylston stage are traversed near their 
shoreward margin by the electric railway. One of these remnants is abont 300 acres in extent. The surface altitude is about 460 feet (by barometer), which would indicate that by the time of its formation the drift barrier in the Boylston outlet had been cut down somewhat by the outflowing waters (fig. 10, $B$ ). This broad terrace is directly opposite the small kame terrace and delta occurring at the

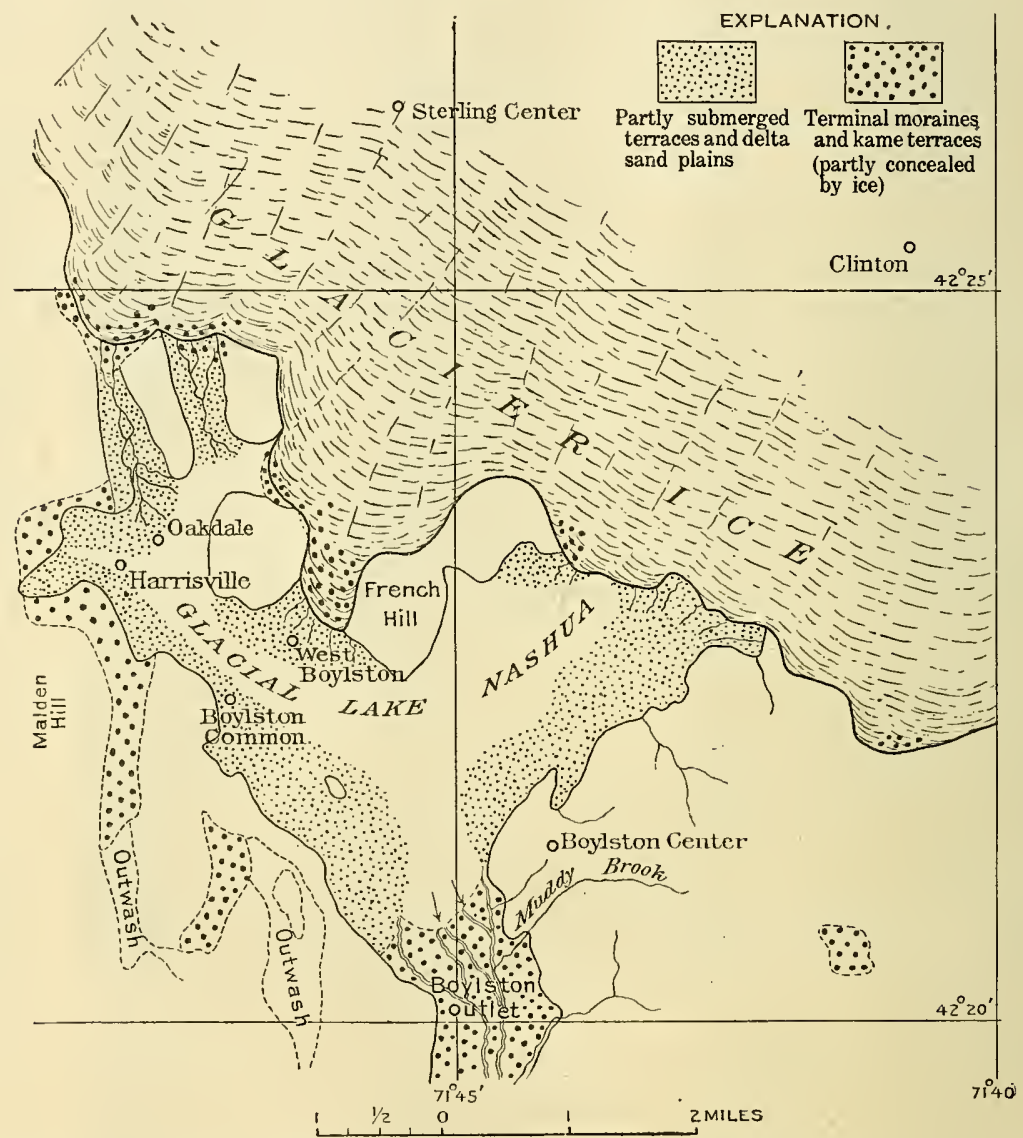

FIGURe 11.-Diagram illustratius relations of the ice front to glacial Lake Nashua near the end of the Boylston stage.

Boylston level on the west side of the valley $3 \frac{1}{4}$ miles southwest of Clinton. These deposits, with the gravel extending along the east side of the valley to the south-dike outlet, are the most northerly deposits to be correlated with the Boylston stage. The northeast margin of the broad terrace is abrupt and lobed and drops down 70 feet to the level of the Clinton terrace. This scarp is an ice-contact slope and apparently marks the latest position of halt of the ice front before the opening of the south-dike outlet (fig. 11). 
That it is at an ice contact is further shown by the fact that into it merge two eskers, which when seen were partly submerged by the waters of Wachusett Reservoir (Pl. XII, $B$ ). These eskers mark the position of streams that discharged into the lake from the ice front and spread their detritus in a broad delta.

\section{DEPOSITS OF THE CLINTON STAGE.}

Because of the position of the south-dike outlet and the fine preservation in the vicinity of Clinton of the terraces formed when the waters discharged through this outlet, this stage of the lake has been designated by Crosby the Clinton stage. Prior to the building of the south dike of Wachusett Reservoir the outlet stood about 360 feet above the sea, but it was probably about 30 feet higher when first opened, inasmuch as the Clinton terraces southwest of the outlet have altitudes of approximately 400 feet. (See Pls. VI and XVIII and fig. 10, $C$.) From the vicinity of the bridge at Boylston Common a fiat terrace 150 to 650 feet in width extends southeastward along the south side of the valley, between the abrupt erosion slope that drops 60 to 80 feet to the submerged bottom of Nashua Valley on the north and the marginal slope of the higher Boylston terrace on the south, as far as the submerged valley of Muddy Brook. The old stone church stood on a slight remnant of this terrace near the north end of the bridge, but east of this point for about half a mile the terrace has wholly disappeared. From the south end of French Hill northeastward to a point due west of the south-dike outlet a narrow strip remains at 395 to 405 feet above sea level. Slight remnants of this lower terrace also occur on the east side of the valley between Muddy Brook and the south-dike outlet.

At the time of the writer's visit the river valley was submerged up to the 367 -foot level, leaving the upper 30 feet of the material underlying the Clinton terrace exposed in sections kept clean by frequent slumping. Southeastward from Boylston Common to the vicinity of the quartzite hill the upper 5 to 15 feet consists of gravel ranging from fine pebbles to cobblestones. Beýond this point the upper gravel is absent from the section. Beneath the gravel is 5 to 30 feet of stratified sand in delicately rippling layers, with the cross lines showing that the direction of wash was toward the southeast. The lower part of the section, ranging in thickness from a few inches to 10 feet above the water, is made up of fine interlaminated sand and clay. The clay layer's in places contain abundant clay-iron concretions formed about tubelets.

The opening of the south-dike outlet must have caused a rapid lowering of the lake from the 480 -foot level to the 400 -foot level. This change increased the gradient of all the streams flowing into the lake very notably, so that they attacked the drift deposits in 
their valleys with renewed energy, cutting them away and depositing the detritus in the lake. Drainage from the ice front contributed much, and the lake waters themselves accomplished more or less erosion of the deposits of the Boylston stage along their shores, so that probably the deposits described above filled the valley from side to side almost if not quite up to the water level. Indeed, the lake may have been entirely filled up so that in its place a stream meandered over a broad flood plain. The gravel deposits mark the final stages of the filling.

From the latitude of the south-dike outlet, where Nashua River swung toward the east side of the valley, northward nearly to South Lancaster, the deposits are much better preserved and are spread out 1 to $1 \frac{1}{2}$ miles in width, filling the broad ancient valley west of Clinton from side to side except where interrupted by iceblock depressions and small eroded ravines (Pl. XVIII). At the point where this broadening begins the terrace drops about 15 feet by a short slope to an altitude of 380 to 385 feet, so that this plain is submerged when Wachusett Reservoir is filled up to the 395foot level. Crosby ${ }^{18}$ has discussed in detail these deposits of the Clinton stage.

Through an east-west belt about 330 feet wide just north of this short slope the terrace is closely pitted with kettleholes (Pl. XIX, $A$ ), but beyond this to the submerged valley of Cunningham Blook pits are fewer. These pits indicate the burial of abundant large masses of ice and the continuance of these masses intact while the plain to the north was being built up. The structure and composition of the deposit exposed above water level at the time of the writer's visit are essentially the same as those noted farther south, except that the beds dip generally toward the south, or in a direction away from the ice front. The structure shown in Plate $\mathrm{XIX}, B$, is that of fore-set and bottom-set beds of a delta, the bottom-set beds consisting of alternate layers, one-fourth to 1 inch thick, of buff brown sand and bluish slightly clayey sand. A little to the east of the section shown in Plate XIX, $B$, the stratified sand is overlain by horizontal beds of gravel in which the largest cobbles are 1 foot in diameter.

This delta plain is separated from that to the north by the submerged valley of Cunningham Brook. Crosby's examination of this valley before its submergence led him to regard it as virtually a fosse between a normal steep and irregular ice-contact margin on the south and a normal gentle and lobate frontal slope of the delta plain on the north, thus marking the next position of halt of the ice margin in its retreat.

\footnotetext{
is Crosby, W. O., Structure and composition of the delta plains formed during the Clinton stage in the glacial lake of Nashua Valley: Tech. Quart., vol. 16, pp. 240-254; vol. 17, pp. 37-75, 1904.
} 
North of this valley is the extensive plain across which is built the north dike of Wachusett Reservoir. The surface of the eastern part of this plain has been considerably modified by grading incident to the construction of the north dike and cut-off. The structure and composition of the deposits were thoroughly explored by Crosby in the trench for the main cut-off, which had an aggregate length of 9,556 feet and a maximum depth of 60 feet, and in that for the shorter secondary cut-off, and by the examination of samples from more than a thousand wash-drill borings systematically distributed on the plain with an average depth of 83 feet and a maximum depth of nearly 300 feet. The general altitude of this plain is about 380 to 385 feet, there being a gentle slope toward the south, and except for ice-block depressions, in one of which lay Sandy Pond and the channel (now filled) that connected it with Coachlace or Clinton Pond, the plain is continuous across the ancient valley from east to west, entirely surrounding a group of rock ridges that rise above it. South of Wachusett dam this plain terminates in a maze of interlacing kames and kettles, now submerged. At the north it ends in a pitted ice-contact slope at the south margin of the Coachlace Pond. The basin occupied by this pond is regarded as a fosse marking the next position of halt of the ice front. That part of the plain west of the rock ridges is but little broken by depressions, and borings show the thickness of the deposits to range from a few feet to about 190 feet. The axis of Sandy Pond and adjacent depressions was found to coincide approximately in position and trend with the deep preglacial bedrock gorge of Nashua River, discussed above in connection with the Tertiary drainage system (pp. 23-27). The depressions are not directly above the buried gorge but are superposed, with 100 to 130 feet of assorted drift intervening, upon a distinct bedrock terrace several hundred feet wide and having an altitude of 190 to 210 feet, which separates the gorge from a buried ridge of schist that rises within 100 feet of the surface of the plain. This broken east half of the delta plain, according to Crosby, overlies an unusually rugged bedrock surface, with a maximum relief of nearly 300 feet and a corresponding variation in the thickness of the drift above it. The surface of the rock beneath this drift was found to be fresh and unweathered.

Exploration of the deposits beneath the north-dike plain showed that the filling of the ancient rock valley was almost all water-laid drift, till being notably absent. The till mantle extending down the side slopes into the valley dies out within a short distance beneath the stratified deposits. Southward down the sloping bedrock plain the till increases somewhat, and in two or three of the most southerly profiles it is practically continuous above the rock and ranges in thickness from 2 to 30 feet. The water-laid drift that 
forms the bulk of the filling ranges from coarse gravel at the top to very fine sand and clay at the bottom, assorted and stratified in topset, fore-set, and bottom-set beds as in a normal delta. The borings did not as a rule reveal the attitude or dip of the three groups of beds, so that conclusions relative to their thickness were based on the assumptions that medium and fine sand belonged especially to the fore-set beds, rock flour to the bottom-set beds, and very fine sand in an intermediate position, marking the transition from fore-set to bottomset beds. These assumptions were sustained by observation wherever sections of the deltas were seen. Crosby says that although the trend of the cut-off was at most points transverse to the direction of delta growth, the walls of the great trench, 30 to 60 feet deep, showed in general below the coarse gravel of the horizontal top-set beds, rarely more than 10 to 15 feet thick, southward-sloping layers of medium to fine sand. Concerning the structure of the deposits Crosby says in part:

To summarize, the north-south profiles of the westerly portion of the northdike plain reveal a normal delta structure, with the bottom sets rising to the southward and both the bottom sets and fore sets becoming, on the average, of finel texture in that direction. East of the cemetery ridges, but heading against the same ice contact on the north, the growth of the delta was similar but chiefly easterly to a lateral ice contact along the western borders of Coachlace and Sandy ponds. East of the ponds the development was again normal, from a head ice contact on the north and with a lateral ice contact on the west. In this case it may he noted in addition that the profiles cross the fead contact and thus give in that direction coarser material and more complete sections than for the westerly profiles.

Between the bottom-set beds of rock flour and the bedrock in many places was found a basal layer of gravel and coarse sand ranging from a few inches to several feet in thickness. This material was thought to be the detritus spread over the intervening tract during the recession of the ice margin from the head of one delta to the head of the next delta of the series.

Crosby's studies also afforded him the basis for certain deductions concerning the origin of the kettleholes that pit the delta plain. Beneath the floor of the channel (now filled) that connected Coachlace and Sandy ponds was found 120 to 130 feet of very fine sand and rock flour regarded as forming bottom-set beds. The top of this deposit also was found to extend out under the bordering plain at approximately the same level, with, in general, no indication of slope toward the great kettle. Above this level as a rule were only the normal foreset materials, chiefly medium and fine sands, overlain by 5 to 20 feet of coarse top-set beds. From this relation Crosby concluded that

The depression ss due to the melting of a block of clear ice at least 50 feet thick, which rested on the impalpable bottom sets at about elevation 325 while 
it became inclosed by the advancing foresets. That the ice block rose above the surface of the water and thus escaped complete burial seems to be proved by the general absence of top-set detritus on the floor of this trough.

The altitude at which the mass of ice must have lain led to the conclusion that it was a stranded berg, rather than a residual portion of the decaying ice sheet. Beneath another kettle borings showed practically a complete absence of bottom-set sediments and a more or less distinct inward slope of fore-set and top-set beds, indicating that here the ice block, 50 feet or more in thickness, was probably a residual mass resting on the valley bottom and buried by fore-set and top-set materials, which settled as the ice melted. The relations of deposits beneath other kettles cut through by the cut-off trench indicated that ice masses were stranded on the top of the bottom-set deposits and subsequently buried by fore-set and top-set materials. In one place the structure showed that a comparatively small block of ice was stranded and buried and then melted, causing the settling of the overlying beds, and the depression was then filled by continued deposition. Crosby concluded "that the kettles of the north-dike plain are probably as diverse in origin as in form " and that "pretty much all known or suggested conditions of kettle formation were realized simultaneously in this limited area."

North of the transverse part of Coachlace Pond the gravel plain, more or less broken and uneven, extends to the line of the New York, New Haven \& Hartford Railroad. North of the railroad on High Street a 40-foot slope leads up to a broad, flat plain nearly threequarters of a mile in extent and having an elevation of nearly 360 feet above sea level, or approximately that of the lowest part of the south-dike outlet, and terminated at the north by an abrupt slope, 40 to 100 feet in height, which is partly an ice-contact slope and partly eroded.

These several delta plains, each heading at an ice-contact slope and fosse, mark the progress of the retreat of the ice front bordered by Lake Nashua, while the waters discharged through the southdike outlet. North of South Lancaster for a distance of 4 miles, in the whole valley, 2 to $2 \frac{1}{2}$ miles in width, no terraces or deltas occur at levels corresponding with the south-dike outlet. North and northwest of Whittemore Hill, however, in the town of Lancaster, partly within the Quinsigamond quadrangle, occur similar pitted delta plains of sand and gravel at altitudes of 300 to 400 feet-tliat is, at levels somewhat higher than the last of the delta plains south of South Lancaster. The occurrence of only deposits of a later and lower stage in the valley north of Clinton over so broad an area, although the sand and gravel plains north and northwest of Thittemore Hill rise 100 to 180 feet above the valley bottom, is regarded as evidence that the sand and gravel of these plains may have been 
laid down while yet the ice lobe in the valley extended south to the ice-contact slopes near Clinton ${ }^{19}$ (Pl. XVIII). These high gravel terraces have in part ice-contact slopes at the north and in part merge into deposits showing morainal topography. The stream that formed them must have been connected with the open lake near Clinton by way of the valley of Wekepeke Brook and the col southeast of Pratt Junction, which has an altitude of 420 to 430 feet, or along the east slope of Ballard Hill. No evidence of the flow of glacial waters along this slope or across the crest of the hill was noted, but in the valley of Wekepeke Brook considerable deposits of sand and gravel occur. These deposits, however, which are mapped as glacio-lacustrine, rise to somewhat higher levels than the sags in the crest of Ballard Hill and are in part at least morainal and of earlier deposition. As the ice melted in the valley north of Clinton the water in Wekepeke and North Nashua Valleys lowered to the level of the south-dike outlet, causing partial erosion of the deposits and forming a second terrace, at 360 feet above sea level, north of the stream east of Gates Crossing. No stratified materials were noted on the slopes of Ballard Hill.

Between 2 and 3 miles north of Still River station is a broad terminal moraine, which is the first indication of a definite halt of the ice front in the valley in a distance of 6 miles northeast from the ice-contact slopes near Clinton. ${ }^{20}$ As the ice melted the lake extended northward, yet through this whole distance no deltas or terraces other than those indicated appear to have been formed. The reason for this is not apparent. Gravel extends up all the valleys tributary to the lake on the north and west, notably in North Nashua Valley, so that most of the coarser material carried by the streams in these valleys may have been dropped before it reached the lake. Moreover, some of the drainage from the frontal slope of the ice margin may have been diverted eastward away from Nashua Valley at points north of the Quinsigamond quadrangle.

The only deposit representing this latter part of the Clinton stage is fine laminated silt or clay, now overlain by sand and gravel of a terrace of a later stage. The best exposure of this clay seen by the writer was at the New England Brick Co.'s plant, half a mile west of Still River Station, where an excavation was being made in the abrupt margin of a broad terrace $(\mathrm{Pl}$. XX, $A)$. Here the upper 10 to 12 feet consisted of cross-bedded sand and fine gravel, forming the terrace top. Beneath this and above the level of the floor of the

\footnotetext{
10 Professor Emerson states in a personal communication that a study of the area to the north of the Quinsigamond quadrangle has made it appear probable that these deposits are connected with the Clinton stage.

${ }_{20}$ Atwood, W. W., The country around Camp Devens (description printed on back of topographic map of Camp Devens and vicinity), U. S. Geol. Survey, 1919.
} 


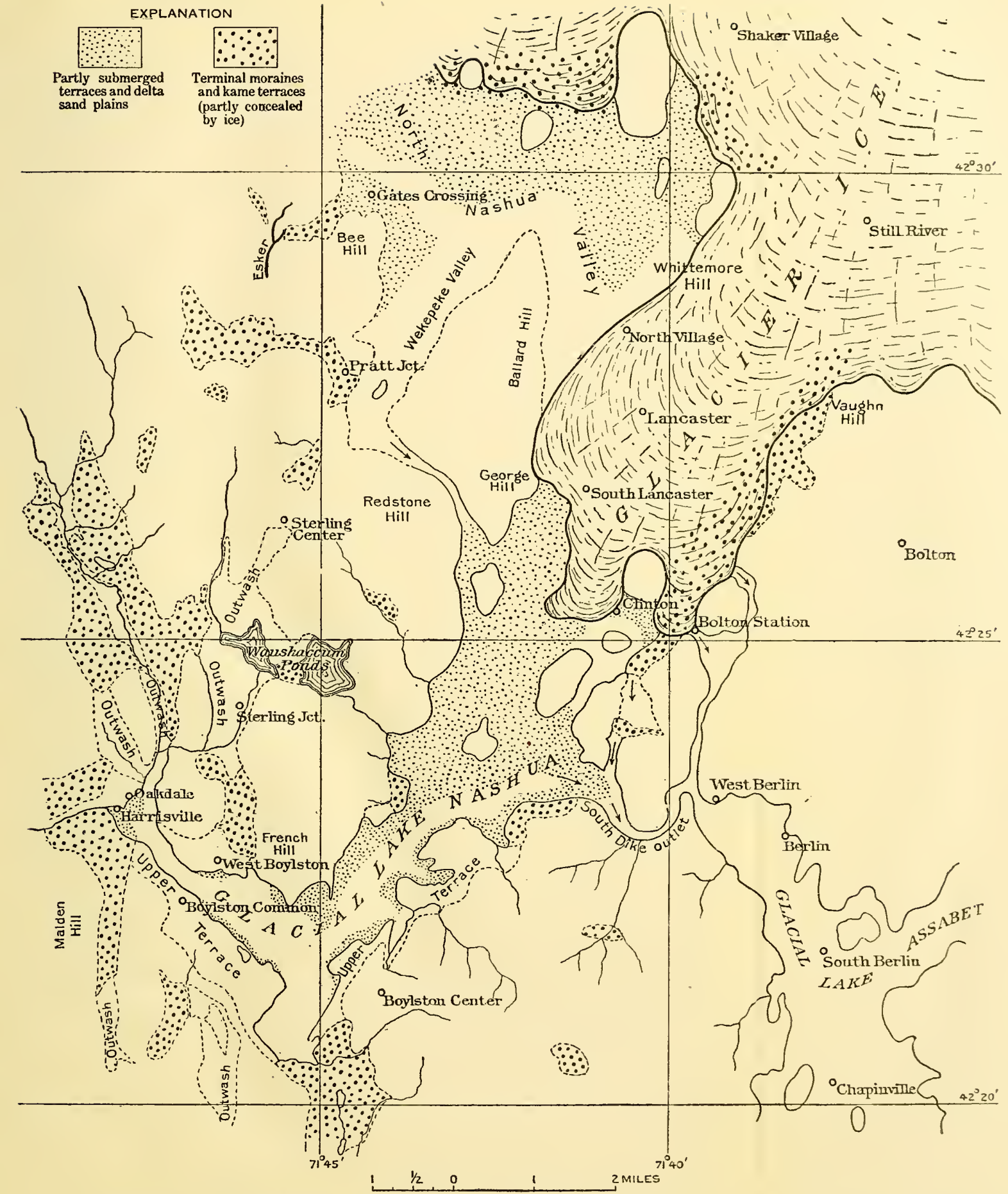





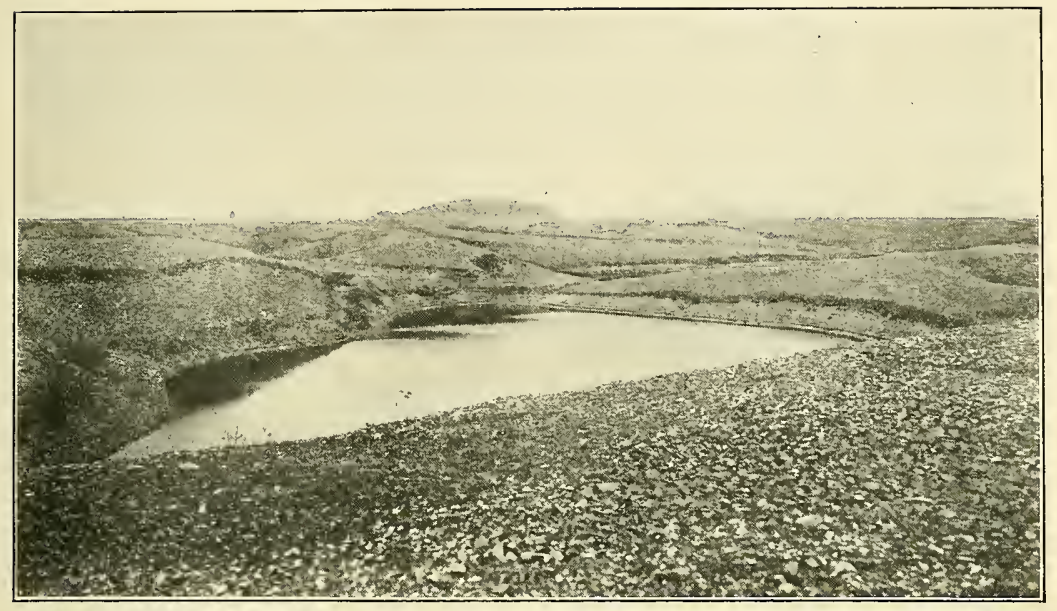

A. KETTLE HOLES IN SAND AND GRAVEL SOUTH OF CliNtoN, Mass.

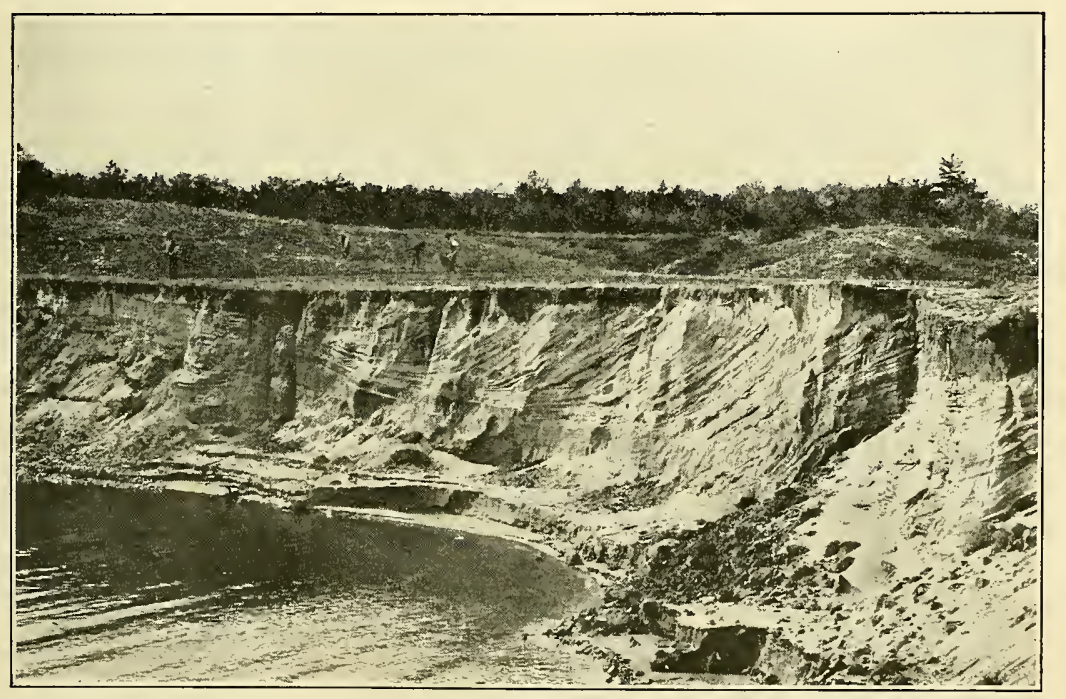

B. FORESET AND BOTTOMSET BEDS OF SAND PLAIN 3 MILES SOUTHIVET OF CLINTON, MASS. 


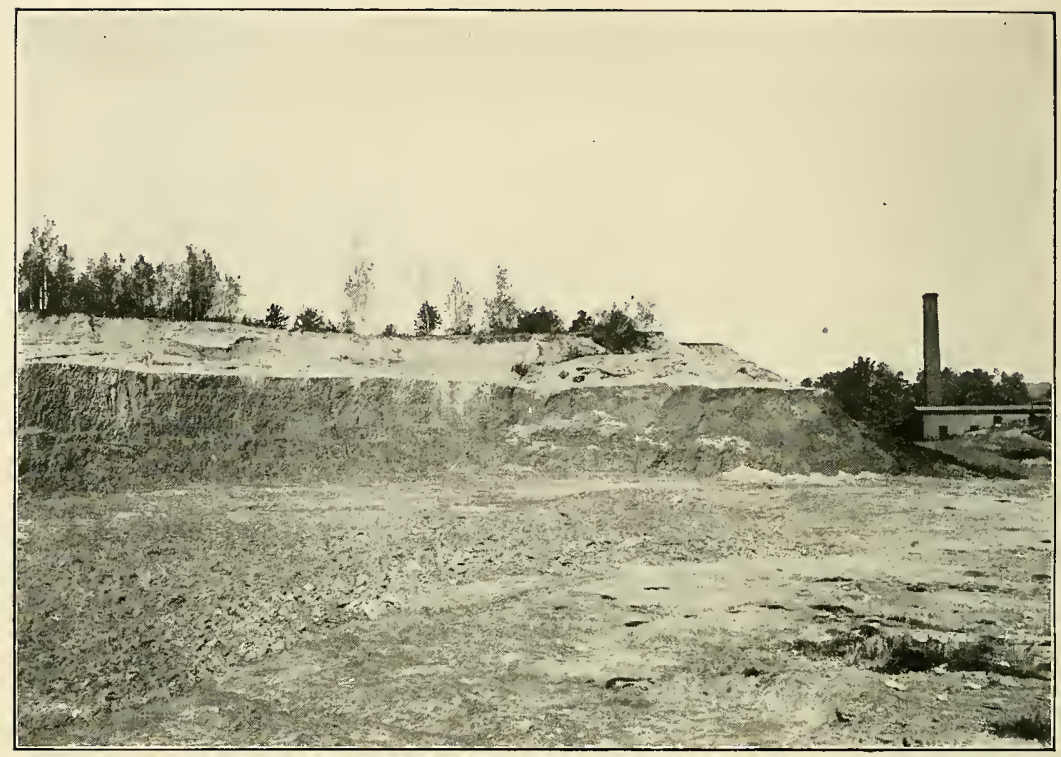

A. CROSS-BEDDED SAND OVERLYING LAMINATED CLAY, STILL RIVER STATION, MASS.

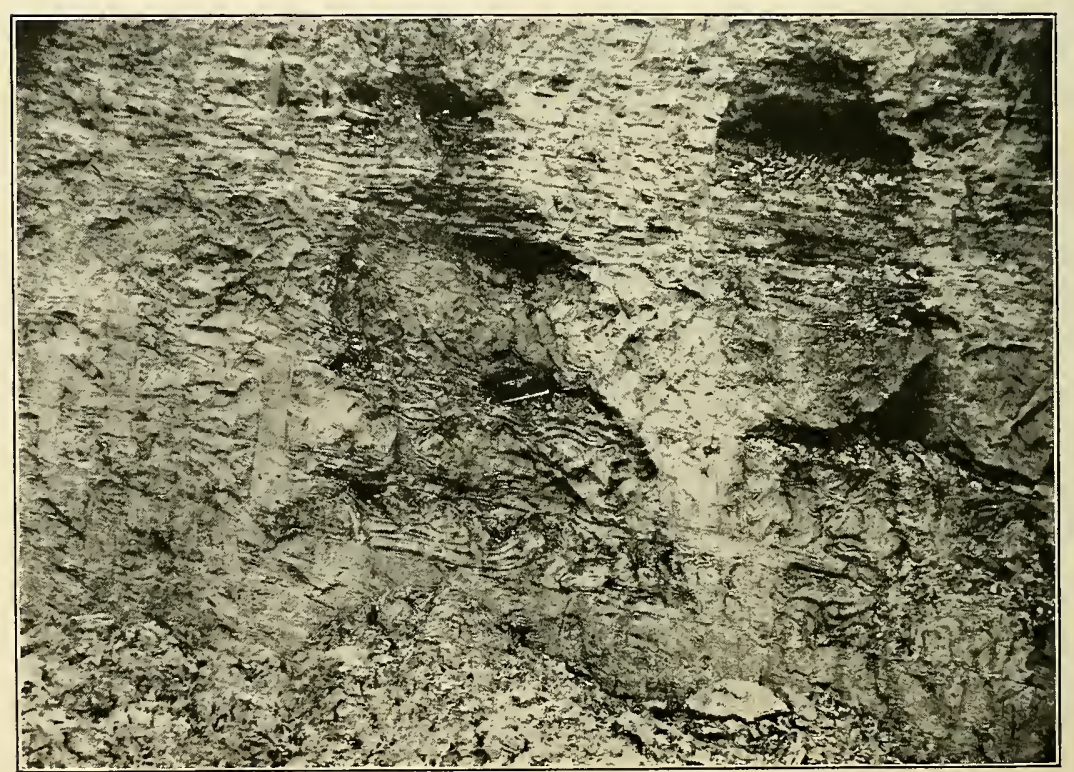

B. LAMINATED AND CRUMPLED LACUSTRINE CLAY, STILL RIVER STATION, MASS. 
valley was exposed 12 to 14 feet of blue stoneless laminated clay, with alternate layers slightly sandy and less dense. The depth to which this clay extends below the level of the valley floor is not known, but at one point $c$ low ridge of stony blue clay (glacial till) rises a few feet above the floor, and the laminae of the overlying clay dip with the slope of its surface. About the middle of the section are three beds, $1 \frac{1}{2}$ feet, 1 foot, and 10 inches in thickness, in which the laminae are closely crumpled in little folds (Pl. XX, B). Between, above, and below these beds are regular undisturbed laminae. The little folds are not regularly overthrust toward the south, nor is there any coarse or unassorted drift on the several contorted layer's, or other evidence of a readvance of the ice front, such as wouid indicate that the glacier had thrice overridden the laminated clay. It is more probable that the contortions are due to the repeated grounding of icebergs or ice floes on the soft clay bank. The rising, sinking, and turning of such grounded masses with the movement of the water might contort the clay laminae to a depth of a few inches, as seen here. Continued deposition after each interruption covered the disturbed beds with regular laminae. If it is assumed that each layer of the laminated clay represents the total accumulation of a year's slack-water deposition of fine sediment in the lake, just as each of the concentric rings in the trunk of a tree represents a year's growth, a rough estimate might be made of the minimum duration of the later part of the Clinton stage of glacial Lake Nashua, while the ice front stood at the moraine between Still River Station and Ayer and before the waters shallowed enough to permit the deposition of the cross-bedded sand and gravel that overlies the clay.

The clay is exposed in the bank northward for some distance beyond the limits of the Quinsigamond quadrangle. Just south of the clay pit the surface of the clay drops down in the section, so that for some distance north of the road the whole section consists of stratified sand and gravel. Similar clay was also exposed at an old brickyard on the east side of the valley, about three-quarters of a mile north of Still River Station. It is reported that clay was dug for brick nearly 45 years ago in the lower slope of Whittemore Hill, at the Burbank place.

One mile northeast of Lancaster a pit just east of the railroad, owned by E. \& R. N. Farnsworth, exposed 8 feet of laminated clay beneath 5 feet of sand and gravel when seen by the writer. ${ }^{21}$ Except for the upper foot, in which some pebbles are mixed, the clay,

${ }^{21}$ Alden, W. C., Fuller's earth and brick clays near Clinton, Mass.: U. S. Geol. Survey Bull. 430, pp. 402-404, 1910.

$92817^{\circ}-24-5$ 
which is used for fuller's earth, is almost wholly without stones, though occasionally berg-dropped boulders are found in the deposit. It is said that a thickness of at least 26 feet was shown at one point by excavation and boring, and that the deposit thins up the slope to 8 feet at the west side of the railroad, the average being perhaps 15 feet. Lower down the slope to the east the stony blue till is exposed. The laminae are slightly undulating, and it is said that in places in digging they have been found folded and tipped up on edge. These beds of laminated clay were evidently deposited as silt in the open lake, free from coarse detritus except that dropped from floating ice, and hence not in the immediate vicinity of the ice front. It is believed that they were laid down in the waters of the Clinton stage, while the ice front stood at the moraine 2 to 3 miles north of Still River Station.

Examination of the clay under the microscope shows it to be composed of minute angular fragments of various minerals, principally quartz and feldspar, ranging from an upper limit of grains 0.5 millimeter in diameter down to the limit of vision. A sample from the New England Brick Co.'s clay bank shows the grains to be very uniform in size, only a small percentage being larger than oneseventieth of a millimeter in diameter. Clay taken from the middle of two of the exposures showed the following chemical composition:

Analyses of clay from Worcester County, Mass.

[George Steiger, analyst.]

\begin{tabular}{|c|c|c|c|c|c|}
\hline & 1 & 2 & & 1 & 2 \\
\hline $\begin{array}{l}\mathrm{SiO} \\
\mathrm{Al}_{2} \mathrm{O}_{3} \ldots \ldots \\
\mathrm{Fe}_{2} \mathrm{O}_{3} \ldots \ldots \\
\mathrm{FeO} \\
\mathrm{MgO} \\
\mathrm{CaO}\end{array}$ & $\begin{array}{r}66.65 \\
16.93 \\
3.05 \\
.84 \\
.96 \\
1.07\end{array}$ & $\begin{array}{r}57.88 \\
20.68 \\
3.94 \\
2.08 \\
1.60 \\
1.03\end{array}$ & $\begin{array}{l}\mathrm{K}_{2} \mathrm{O} \\
\mathrm{H} \mathrm{H}_{2} \mathrm{O}-\ldots \ldots \\
\mathrm{H}_{2} \mathrm{O}+\ldots \\
\mathrm{T}_{\mathrm{jO}} \mathrm{O}_{2} \ldots \ldots \\
\mathrm{CO}_{2} \ldots \ldots\end{array}$ & $\begin{array}{r}3.60 \\
1.54 \\
3.03 \\
.80 \\
\text { None. }\end{array}$ & $\begin{array}{r}4.74 \\
1.38 \\
3.63 \\
.88 \\
. .6\end{array}$ \\
\hline $\mathrm{Na}_{2} \mathrm{O}_{3} \ldots \ldots \ldots$ & 2.05 & 1.99 & & 100.52 & 99.83 \\
\hline
\end{tabular}

1. Farnsworth pit, northeast of Lancaster.

2. Brickworks west of Still River Station.

DEPOSITS OF THE AYER STAGE.

Through most of the distance of 9 miles from Clinton northward to Shirley, Nashua River is bordered on the west by terraces having an altitude of 260 to 270 feet above the sea. These terraces correspond approximately with the level of the outlet near Ayer. Thus it appears that they were formed when the retreat of the ice had cleared this outlet and allowed the lake to be drawn down from the level of the Clinton stage. Crosby reports that the deposits south of Wachusett dam near the river, now largely submerged, were lower and much more pitted and discontinuous than those farther west. Apparently this must also have been true of the filling of the gorge 
at the site of the dam, so that as the lake lowered the course chosen by the resulting stream was through the gorge instead of across the broad sand plains west of Clinton, beneath which the ancient main channel is buried. This was the beginning of the Quaternary Nashua River, and the course then chosen has never been abandoned, though the removal of the drift filling of the gorge has superimposed the stream on the rock divide in the ancient col. With the lowering of the water the stream attacked the gravel, sand, and clay so largely filling the valley above Clinton and swept the detritus through the gorge and into the open lake at the north. This detritus, with that brought in by other streams, notably the North Nashua, was spread out over the laminated clay in extensive terraces, the distribution of which is shown on the map (PI. VI). Terraces are well developed on both sides of the present flood plain from Clinton to Lancaster Commons and South Lancaster. At the latter place a pit in the south margin shows poorly assorted and poorly bedded sand and gravel, and an exposure near the railroad crossing in the eastern part of the village shows cross-bedded sand and gravel dipping to the east, as in a delta deposit formed by wash from the North Nashua Valley.

Lancaster stands on a till-mantled rock ridge, but the marginal slopes are coated with sand and gravel up to about this lake level. East of Whittemore Hill, and separated from it by a marshy sag and abandoned channel, is an extensive flat terrace which terminates at the east in an abrupt 50-foot erosion slope, where the surface drops down to the present flood plain. At some places the meandering stream cutting into the foot of this slope exposes the stratified sand and fine gravel. Farther north, bordering the base of the abrupt 100-foot marginal slope of the high sand plain, is a similar terrace, which continues north to Shirley, a distance of 4 miles, varying in width from a quarter of a mile to 1 mile. It is in the abrupt east margin of this terrace that the laminated clay is exposed at the New England Brick Co.'s yard, as mentioned above (p. 70). The surface of this clay is more or less uneven, and a few rods sonth of the brickyard the clay disappears entirely from the section. Overlying the clay is 10 to 50 feet of sand and gravel so disposed as to give to the terrace a nearly flat surface. This sand and gravel is beantifully cross-bedded, as is characteristic of shallow-water deposits along ancient shore lines, but does not show the differentiation into top-set, fore-set, and bottom-set beds characteristic of a delta. Continued recession of the ice front at length caused the draining of that part of the basin within the Quinsigamond quadrangle and the further erosion of the deposits in the main and tributary valleys and completed the development of the broad flood plain of Nashua River north of Clinton. 
GLACIAL LAKE ASSABET,

The history of glacial Lake Assabet began when the ice front had melted back to the basin of Whitehall Pond, between 2 and 3 miles sonthrrest of Westboro. The water found its first ontlet from this basin southwestward through the col to Warren Brook. The first deposit was the sand and gravel underlying the small flat plain that borders the southwest slope of the pond. The swamp south of this plain, marking the position of the open water, is probably underlain by the finer silt.

North of the pond is an extensive deposit of stratified sand and gravel, of which the higher parts are flat and somewhat pitted with kettles. At the north margin it is joined by an esker, described abore (p. 51), which marks the position of the stream discharging from the ice front into the small lake at the time the moraine to the west was being formed. When the ice front stood at the moraine west of Westboro the water escaped southwestward through the col traversed by the railroad. An excavation near the stream exposes fine laminated sand and clayey sand, including berg-dropped boulders.

Continued recession of the ice front opened an outlet to the east, through the valley of Sudbury River, traversed by the Boston \& Albany Railroad at Southville. Throughout most of that part of the basin south of the New York, New Haven \& Hartford Railroad sand and gravel are spread so as to form a nearly flat plain, of which the general altitude is 300 to 320 feet above sea level. 'This is higher than that part of the Sudbury Basin east of Westboro and the outlet to the east, so that the deposit may have been completed as fluvial outwash. The surface is much pitted and in places has a mild morainal aspect. An eskerlike ridge west of Bartlett Pond indicates the position of a glacial stream. Northeast of the Worcester County Insane Hospital, which stands on the hill northeast of Chauncey Pond, and north of the New York, New Haven \& Hartford Railroad, the general altitude of the gravel plain is about 280 to 300 feet above sea level. This corresponds to an outlet eastward to Reservoir No. 5 by the valley of Stony Brook, now traversed by the Wachusett Aqueduct. On this plain and on erosion remnants of it stand the villages of Northboro and South Berlin and part of West Berlin. Numerous cuts expose the stratified sand and gravel and show that most of the pebbles are less than 4 inches in diameter, but cobblestones and boulders, some very large, are included. In the valley slope at Chapinville fine laminated sand and sandy clay are exposed beneath the gravel. Boulders are generally present on the surface of the plain, which is also pitted more or less by small sags and some larger ice-block depressions. Apparently the depo- 
sition took place near the ice front, and some of the abrupt 40 to 50 foot slopes bordering the streams and ponds appear to represent ice contacts. A small terrace with abrupt ice-contact slopes bordering the ridge slope at an altitude of 280 feet 1 mile southwest of Hudson indicates that the lake extended thus far down the valley while yet discharging through the outlet south of Southboro. Some of the sand and gravel in the northern part of the basin may have been brought in by the outflow of Lake Nashua, as there was a difference of about 100 feet in the level of the two lakes when they were in communication through the south-dike ontlet. Most of the material, however, probably came directly from the neighboring ice front.

North of Chapinville the gravel of this horizon occurs principally in narrow terraces on both sides of Assabet River and North Brook. At 20 to 60 feet below this level the streams are bordered by a second set of terraces, which decline in altitude from 280 feet above sea level near Berlin to 220 feet near Hudson. These terraces are remnants of a flood plain developed by erosion of the higher valleys, when the melting cleared an outlet by the way of Hudson and the col southeastward to Fort Meadow Brook valley and thence to the lower area on the east. This was the beginning of Assabet River. Continued recession of the ice front opened the cols at Gleasondale and Rockbottom, located the stream in its present course, and caused the development of a bordering flood plain by erosion of the second terraces. When the discharge from glacial Lake Nashua through the south-dike outlet ceased and the waters no longer reached the Assabet basin from the melting ice front, the stream dwindled to its present size. The broad plain extending $3 \frac{1}{2}$ miles northeastward from Hudson has a gentle southward slope, and the upper part of the sand and gravel that underlie it must have been deposited as fluviatile outwash from the ice front, though the basin may have been flooded when it was first freed from ice. The outlets to the east are too low to have permitted submergence of the plain, unless they were blocked by an ice dam. Similar gravel deposited partly in ponded water and partly in drained basins: occupies the valleys north of Assabet River.

GLACIAL LAKES AND STREAMS OF WARE QUADRANGLE.

GENERAL RELATIONS.

At numerous places in the Ware quadrangle there are deposits of gravel, sand, and laminated silt, whose distribution, character, and relations show that they must have been laid down in bodies of standing water, yet no lakes or ponds of sufficient extent to afford the conditions requisite for their deposition now oceupy the valleys 
in which the sediments are found, and the basins are not closed in such ways that bodies of water sufficiently large could be retained. Hence it is concluded that the present outlets were once blocked by barriers, which have since been removed. Such temporary barriers would be afforded by the lobate margin of the great ice sheet, as it slowly melted backward toward the north and west across the area, with numerous succeeding stages of halt or readrance. The melting of the vast accumulation of ice must have afforded an abundance of water to flood erery depression to the limit of its capacity. Valleys that discharged southward or southeastward provided direct avenues of escape for the water, except where the old channels had been left blocked by glacial débris. Most of the streams of this area, however, prior to the advent of the glacier, drained to the Connecticut by way of Chicopee River and its tributaries, as now. Some of the smaller basins near the western margin of the platean drained independently to the Connecticut Valley. The conditions in the valleys show that the glacial drainage was temporarily blocked by the ice on the north.or west, enforcing the belief that the retreat of the ice was slow and marked by a succession of stages and that a great lobe lingered in the valley of the Connecticut after the ice had largely disappeared from the upland farther east. The history of the several temporary glacial lakes in the west half of the quadrangle, together with other features of the glacial drainage system, has been described by Emerson. ${ }^{22}$ The classification here presented on the maps and in the discussion is slightly different from that given by him, but the interpretation of prevailing conditions is essentially the same, the main difference being that in this discussion the attempt has been made to distinguish somewhat more in detail the terminal moraines, outwash plains, deltas, eskers, and kames, as indicating the successive positions of the ice front during its retreat across the Ware quadrangle.

GLACIAL LAKE NEAR SOUTHBRIDGE.

In the southeastern part of the Ware quadrangle, $2 \frac{1}{2}$ miles south of Southbridge, in the head of Lebanon. Brook valley, beneath 6 to 18 inches of black soil, is a deposit of dense blue stoneless lacustrine clay. At the time of the writer's visit this clay was being used by G. I. Wood \& Co. for the manufacture of brick. At one place a boulder 3 by 6 by 8 feet was seen embedded in the clay just as it had been dropped from a mass of floating ice. A narrow ridge of sand and gravel 30 feet high at the north side of the small pond marks the position of the ice front as it blocked the valley, forming a small narrow lake in which the clays were deposited.

22 Emerson, B. K., Geology af old Hampshire County, Mass. : U. S. Geol. Survey Mon. 29, 1898. 
GLACIAL LAKES OF BRIMFIELD AND WARREN.

A terrace of sand and gravel formed where the esker stream discharged from the ice front into the flooded basin near the State line at Mashapaug may be regarded as marking the first stage of Brimfield Lake. The water escaped through a col to the south at 710 feet above sea level. After melting back 3 miles to the north along the valley the ice front again halted, and the glacial waters deposited, in the head of the extended lake, the great terrace or delta of sand and gravel on which the village of Holland now stands. This completely blocked the valley to a height of 720 feet above sea level. The abrupt 80-foot north slope marks the contact of the ice front at this place. Excavations in the flat top of the deposit show stratified sand with cross beds dipping soutl in the direction of flow. Narrow kame terraces border the sides of the valley to the north. About this time also the gravel terrace on which stands the village of Wales was formed in a small lake. The ice front next retreated from Holland to Brimfield and finally to the west side of West and Hitchcock mountains, where it blocked the col leading to the Quaboag Valley, now traversed by the electric railway. Narrow marginal terraces in the northern and western parts of the Brimfield basin, at an altitude of 720 feet, indicate either that the ice continued in the valley at Fiskdale after it had left the basin to the west, or that the drift dam there was higher than now, so that the water was forced to overflow the terrace at Holland. The broad lacustrine plain on which the village of Brimfield stands, which is underlain with sand and fine gravel, has about the same altitude as the top of the drift dam west of Fiskdale-670 to 680 feet above sea levelwhence it appears that the outlet to the Quinebaug was finally opened over this obstruction. For some time glacial waters came to this lake basin from the valleys to the nortl and west, while similar sand and gravel deposits were being formed along the moraines in the valleys of Taylor and Blodgett Mill brooks, east of West Brimfield, and in the basin between Hitchcock and Cedar Swamp mountains.

The clay pit at Massey \& Gardner's brickyard at West Brimfield, about 600 feet above sea level, in the lower Blodgett Mill Brook valley, exposed the following section at the time of the writer's visit:

Section of drift at West Brimfield brickyard.

Buff to brownish sandy till with large boulders on the surface

Feet.

Stratified sand and fine gravel in places

$\cdot 10$

Dense clay with but few stones (in places lamination may be distinguished) ; upper $1 \frac{1}{2}$ feet weathered brown, dark blue below

$0-5$

Same blue clay, said to have been penetrated to further depth of 
These deposits indicate that an earlier temporary lake was formed when the ice front first entered the valley. As the glacier continued to advance southward the silts were buried in till of the ground moraine, and when the valley was again flooded during the deglaciation a great thickness of sand was laid upon the till. About 50 feet of horizontally stratified sand is exposed in section at the brick kiln, and the road from the station eastward to the upland climbs nearly 300 feet over sand, which mantles the rock slope. The altitude of terraces on this deposit indicates that the waters escaped southward between the rock slope and the ice front to the col west of Brimfield, where they entered the main lake basin.

The high terrace of sand and gravel at an altitude of 700 to 720 feet above sea level southeast and southwest of Marks Mountain, near Warren and West Warren, may have been deposited near the ice front in water escaping to Brimfield Lake along the border of the ice. Cuts near the cemeteries in the southern part of Warren exposed at the north end coarse gravel and farther sonth 20 to 30 feet of buff stratified sand, horizontally bedded in the lower part and with cross beds dipping south at the top.

GLACIAL LAKE BROOKFIELD.

About the time Brimfield Lake reached its greatest extension the ice front began to retire from the moraine in the ralley south of Brookfield and East Brookfield, causing a ponding of water in a lake which extended with the further melting of the ice until the whole Quaboag Valley was flooded as far west as West Brookfield. Until the valley farther west was sufficiently freed from ice this lake discharged to Quinebaug River over the crest of the moraine south of Quacumquasit Pond, or through the cols north and northeast of Walker Mountain. When visited by the writer laminated clays deposited in this lake were exposed at the site of the old brickyard at the west side of the north end of Quacumquasit Pond, near the bridge at the outlet of this pond, at the brickyards at East Brookfield, and at the brickyard north of the electric railroad $1 \frac{1}{4}$ miles east of East Brookfield. The exposures at Qnacumquasit Pond showed 2 to 5 feet of sand and fine gravel, overlying 20 feet of gray to brownish clay with laminae one-eighth to onehalf inch thick and thin partings of brown sand, the amount of sand decreasing downward.

At the East Brookfield yard of the New England Brick Co. the pit exposed, below 7 feet of stratified gravel, laminated stoneless blue clay, which is said to have been penetrated to a depth of 35 to 40 feet before it became too sandy for use. . Just south of the railroad station a cut above the track level exposed coarse gravel over 15 feet of fine stratified sand, and a pit below the track level showed 
10 feet more of finely cross-rippled sand with dips indicating southward wash from the ice front on the north. Extensive sand and gravel terraces or deltas were formed by wash from adjacent ice fronts at East Brookfield, West Brookfield, and the golf links in Ellis River valley.

GLACIAL LAKE QUABOAG.

When the Quaboag Valley between West Warren and Palmer was cleared of ice it became occupied by a glacial lake, which discharged southward over the moraine south of South Monson at an altitude of about 620 feet above sea level. This lake, which temporarily occupied the valley in Palmer and Monson townships, may for convenience be called glacial Lake Quaboag. It was really formed by the flooding of the valley above and below Parksville, but until the Monson outlet was opened it stood at a high level and drained eastward through the col to Brimfield Lake at about 720 feet above sea level, so that the deposits then formed are grouped with those of that lake. As the ice lowered the waters began to escape southward along the broad shelf on the west slope of East Hill, at 640 feet above sea level, and thence south across the moraine in Monson Valley. Later the lake extended west to Palmer, and deltas or terraces of sand and gravel were formed along the ice fronts on the west side of the valley north of West Brimfield, in Kings Brook Valley, and southeast of Palmer Center.

As the ice gradually disappeared from the hilly upland between Monson Valley and the Wilbraham Mountains, a succession of temporary lakes was formed, as shown by terraces of sand and gravel high in the heads of the valleys. These terraces vary in altitude according to the position of the cols that afforded outlets for the waters. All are in such positions that only ice could have formed the retaining dams. None of the cols, however, afforded an outlet for glacial Lake Quaboag lower than that of Monson Valley until the valley extending southward to Hampden, on the east side of the Wilbraham Mountains, was opened. The present divide in this valley is at an altitude of 540 feet, or 80 feet lower than that in Monson Valley. This valley, however, could not have been the outlet for the water for any considerable tine, for no deposits are found at corresponding levels except those in this valley itself. Probably not long after this time the valley traversed by the Boston \& Albany Railroad and the electric railway between Palmer and North Wilbraham, called by Emerson "Ellis Mills Valley," was freed from ice and became the outlet of glacial Lake Quaboag. The altitude of the divide in this valley is now about 370 feet. The rock shelf at the north end of the Wilbraham Mountains, southeast of North Wilbraham, across which the water must first have found egress between the ice front and the mountain slope, stands about 
390 to 400 feet above sea level, so that when this valley was opened there must have been a rapid lowering of the lake about 220 feet or more below the Monson level. When this lowering occurred the drift dam at Blanchardville, $1 \frac{1}{2}$ miles southeast of Palmer, was cut through by the waters in the valley above, and the sand and gravel were swept into the lower part of the lake. Similar obstructions were also cut through near West Brimfield, West Warren, Warren, and West Brookfield, the last two perhaps earlier.

The final stage of glacial Lake Quaboag was reached when the ice in the valley at Three Rivers disappeared and Chicopee River was initiated. The water first broke through between the ice front and the hills to the south over the rock shelf traversed by the road east of Red Bridge, at about 360 feet above sea level, and not until later did it cut the narrow rock gorge now occupied by the river below Three Rivers. From North Wilbraham the water probably flowed southward for some distance between the east front of the Connecticut Valley ice lobe and the west slope of the Wilbraham Mountains, until it reached the open lake at the south end of the glacier. The lowering of the water soon reduced the lake to a stream above West Brimfield. The city of Palmer stands on a fine flat terrace developed at this stage at about 360 feet above the sea. Excavations in this terrace show it to be composed of 3 to 5 feet of coarse cobblestone gravel over fine gray stratified sand. This terrace, now partly eroded by the stream, extends northwestward along the north side of the valley a distance of 4 miles from Blanchardville to Four Corners, with slight remnants on the east side of Monson Valley opposite Chicopee Mountain, also opposite Palmer, and extending southeastward for a mile from Three Rivers. This terrace was probably formed principally by erosion of the higher terraces of the earlier stage and redeposition of the material. Some of its material, however, may have been washed directly from the adjacent ice front, which was retreating up the valleys of Ware and Swift rivers and Broad and Jabish brooks. A small lake held in the valley north of the moraine at Palmer Center discharged southwestward through the col at the village to Ellis Mills Valley but disappeared when there was opportunity for the water to escape around the north end of the hill at Wipples, west of Forest Pond, and reach the outlet at Three Rivers. Extending northward from Three Rivers and Four Corners to the vicinity of Belchertown is a complex deposit formed as the ice front retreated northward. Here and there are bits of flat terraces at altitudes corresponding to the final stage of Lake Quaboag, indicating that the ponded waters extended northward from Three Rivers over the lower tracts as the ice disappeared. Interspersed with these, however, are higher terrace deposits, which must have been formed by outwash directly from 
the ice, and still other higher areas, marked by gentle undulations or knobs and kettles of a terminal moraine. Most of the material is stratified sand and gravel, but some is coarse, bouldery, poorly assorted drift, just as it was dropped from the ice.

WARE AND SWIFT RIVER DRAINAGE SYSTEMS.

The Ware River valley does not appear to have been blocked by the ice in such a way as to form a lake thronghout the valley. As described above the esker in the valley north of Ware terminates in the western part of the village in a terrace or delta on which the cemetery stands. This terrace has an altitude of 480 feet above sea level, and was probably originally continuous with the gravel terrace at a like altitude sonth of the river. 'This may have been formed as an allurial fan or terrace of subaerial outwash by discharge of an esker stream from its ice channel, while the glacier still buried the ralley above Ware; or it may have been formed as an esker delta in a small marginal lake, whose outflowing stream was held up along the slope of the valley to the southwest by the ice front and escaped through the col at Palmer Center, and thence to Lake Quaboag and the Ellis Mills outlet. Though the ice front probably retreated more rapidly over the eastern part of the quadrangle than in the lower and more dissected western part, the trend of the Ware River valley is so nearly southwest that it is doubtful if the upper part of this valley was freed from ice before the Chicopee began to cut its rock gorge and erode the terraces in the vicinity of Three Rivers. The construction of the valley for a mile above the bend at Thorndike suggests that it may have been blocked by a drift dam up to a level 400 to 420 feet above the sea. This dam, however, would not have flooded the valley above Ware. That it was flooded up to this level in front of the ice between Thorndike and Ware appears from the well-marked terraces at this altitude. The relations of these features, however, indicate that the material composing them was washed directly from the adjacent ice front. One of the terraces or deltas merges with the south end of the esker, and that in Beaver Brook valley terminates at the north in pitted deposits and a wellmarked ice-contact slope. Cuts near the south end of the terrace show it to be composed of stratified sand and fine to 3-inch gravel over finer laminated gray sand, evidently deposited in the lake. Possibly an arm of the glacial lake in Quaboag Valley extended up the valley to Ware, while still the ice blocked the outlet at Three Rivers and forced the flow through Ellis Mills Valley.

There is some slight indication that the valley was blocked by drift at Gilbertville and that the higher terrace 1 mile to the east may have been deposited in ponded water due to such a dam near the bend at the village, or it may be an outwash terrace formed 
immediately in front of the ice. The lower terrace bordering this at the bend of the river, traversed by the Boston \& Albany Railroar, is the result of subsequent erosion by the stream.

At Furnace the schoolhouse stands on a terrace 60 to 70 feet above the stream at an altitude 660 to 680 feet above sea level. A 30 -foot cut of the Boston \& Albany Railroad through this terrace shows it to consist mainly of stratified sand and gravel, though there is coarse cobblestone gravel at the north end, where it is somewhat pitted. Similar deposits on the opposite side of the valley at New Braintree Station indicate that the valley may have been filled clear across by wash from the ice front as it lay in Moose Brook valley, to the north. It is not evident how the valley conld have been flooded up to this level, but this deposit may have so obstructed it for a time as to hold a lake above it while the ice retreated, and in this way may have been deposited the broad terrace now cut through by the stream that extends from Wheelwright to Barre Plains and the moraine at South Barre. The deposit on the east side at the cemetery opposite Wheelwright has the appearance of being a delta formed directly in front of the glacier where a stream held by the ice against the valley slope discharged into this lake. Above South Barre the drift in the valley is principally morainal, with but few slight terrace remnants.

High in the valley of Bell Brook, 3 miles northeast of New Braintree, partly eroded terraces of sand and gravel indicate the existence of a temporary glacial lake not long before the Ware River valley was cleared of ice. A similar deposit occupies the valley of Winimusset Brook, northwest of New Braintree.

A considerable deposit of sand and gravel 2 to 3 miles east of Dana is probably in part morainal and in part formed in a temporary lake held up among the hills by the ice front as it continued its retreat northwestward across Worcester County. At one point a cut in this deposit exposed 15 feet of sand and fine gravel over 10 feet of stratified and finely cross-rippled sand, in. which the dip shows the wash to have been from north to south.

Extending northward through the towns of Greenwich, Prescott, and New Salem is a broad valley drained by the Middle and East branches of Swift River. The bottom of this valley is a nearly flat plain, $1 \frac{1}{2}$ to 2 miles in width, in the midst of which rise several very abrupt hills, remnants of the ancient dissected uplands (Pl. VIII, $A$ ). Surrounding these hills and extending from side to side across the broad valley, except in some depressions and the shallow inner valleys cut by the streams, is a deposit of stratified sand and gravel laid down during the retreat of the ice front northward along the trough. The conditions indicate that a very large amount of water from the melting glacier escaped southward through this valley. Yet it is 
not clear that the valley was occupied by a continuous lake. The relations suggest rather that the filling is glacio-fluvial and was laid down by successive stages from south to north and later partly eroded. South of Mount Lizzie is a fine example of lobed sand plain or delta, with a pitted top 500 feet above the sea, probably formed when the ice front stood at Mount Lizzie with lobes on either side. Against this ice front was deposited the higher terrace of sand and gravel by water flowing southward down Beaver Brook valley. Cuts show sand and coarse gravel with pebbles 3 to 12 inches in diameter over 30 feet or more of stratified sand.

North of Mount Lizzie is the flat sand plain on which Greenwich stands. This plain is lower at the south than the terrace south of Mount Lizzie, but it rises gradually northward to about the same altitude at Mount Pomeroy and the hills on the north and east. Apparently the valley here was never entirely filled up to the level of the plains south of Mount Lizzie, but the flat was formed when the lower outlet had been opened by way of Enfield. The plain rises gradually northward to the abrupt marginal ice-contact slopes at Warner and Sunk ponds. A cut near the bridge three-quarters of a mile southwest of Wrarner Pond shows stratified and rippled sand with gentle southward dip. North of Sunk Pond, in the town of Dana, the abrupt knolled and pitted margin gives place to another broad, flat plain surrounding small rock hills and sloping gently toward the break through the ridge now traversed by the Middle Branch of Swift River and the railroad $1 \frac{1}{2}$ miles south of North Dana. So also from a broad lower tract north of Warner Pond a very uniform sandy plain rises gently northward to an altitude of 540 feet at the north ends of Mount L and Russ Mountain. North of these mountains the deposit is more uneven, being broken by kettles, ice-block depressions with ponds, and uneren knolled tracts interspersed with bits of flat plains in which are cut sharp, narrow valleys, suggesting that the disintegrating glacial margin lingered here some time and that considerable masses of ice became buried in the drift. This part of the deposit is mapped as terminal moraine. In like manner were formed the gravel terraces at Dana and Nichewaug.

High in the hills of Prescott and New Salem, west of this broad valley, are sand, gravel, and laminated silt in three small basins, which could have been blocked only by ice dams on the east, and similar deposits in open valleys in the west slope required dams on the north and west. This conclusion is in consonance with the idea that the ice disappeared from the Enfield-New Salem ridge while yet lobes projected southward in the valleys on each side. An excavation in the southernmost basin shows stratified sand dipping gently northwest, toward the col that must have been the outlet. In the 
north basin in New Salem an exposure showed 3 feet of sand and gravel over fine laminated sand and clayey sand upon buff till. All these deposits are much dissected by erosion.

The West Branch of Swift River has cut its channel in a considerable deposit of moraine, kame-terrace, and outwash sand and gravel, which are not readily differentiated, though they were undoubtedly laid down by glacio-fluvial waters as the ice melted on the uplands and in the valleys. The material ranges from fine sand to coarse morainal gravel. Near the junction with the East Branch, southwest of Enfield, are finely developed flat terraces formed after the ice withdrew from the moraine west of Quabin Hill.

GLACIAL LAFE PELHAM AND ASSOCIATED LAKES AND WATERCOURSES.

The complex character of the deposits extending northward in the valleys of Broad and Jabish brooks seems, as noted above, to indicate that they are a combination of morainal, outwash, and lacustrine sediments formed as the ice front retreated to the vicinity of Belchertown. These deposits of sand and gravel extend northwestward on both sides of the Belchertown ridge and terminate in flat terraces at the crest of an abrupt slope 200 feet above the valley of Bachelor Brook, on the west. It is evident from this relation that the glacial front must for some time have remained snugly pressed against this slope and the north slope of the Facing Hills and discharged its detritus-bearing water southward to the Chicopee.

At 140 feet higher, on the east side of the valley of Jabish Brook. $1 \frac{1}{2}$ miles north of Belchertown, is a terrace half a mile in width. A sand pit in the abrupt west slope below this terrace exposed gravel overlying 20 to 30 feet of well-stratified cross-rippled lacustrine sand, showing that the ice front extended northward along this abrupt slope. Similar deposits in the heads of several other valleys, in Pelham, Shutesbury, and Leverett, mark the position of other lakes held by the ice front high on the west flank of the great Pelham ridge. Sand deposits continue northward in the deep, narrow valley of Jabish Brook, under flats on both sides of the brook that rise rapidly until they reach the valley 1 mile west of Packardsville. Here they swing westward and extend across the rock sill to the basin southwest of Mount Lincoln, where they merge into a vast accumulation of fine stratified sand deposited in the most southerly of these lakes. This deposit is much dissected by sharp lavines, and the westward slope drops down very abruptly where the retaining ice wall stood at the time of the deposition. Clearly the water found an outlet, for a time at least, by way of Jabish Brook to the Chicopee. Later the water doubtless broke through to the south, being held high on the rock slope on the glacial front. 
A col at 820 feet above sea level between this basin and that next to the north afforded an outlet for glacial Lake Pelham in the basin of Amethyst Brook. The high level of the upper sand of this Lake Pelham basin indicates that for a time the close crowding of the ice front against the rock slope turned the outflow eastward across the rock sill to Jabish Brook, the two lakes thus being continuous. The Lake Pelham outlet, however, whose flat sandy bottom is now deeply notched by streams at the north and south, leads directly southward and terminates as a hanging valley at the top of a steep slope 300 to 600 feet above Dwight. In a direction a little east of south from this valley and $2 \frac{1}{2}$ miles distant is the pass between the east end of the Holyoke Range and Pelham Ridge in which lie the Belchertown ponds. These ponds occupy ice-block depressions in a plain underlain by sand and fine gravel, which begins just north of the ponds, at the top of an abrupt northwardsloping ice contact nearly 100 feet in height, and declines thence gently southward and southwestward through the valley to a broad lacustrine plain west of Forge Pond in Granby. In this outwash plain Bachelor Brook has since cut its channel. As aptly put by Emerson, "The hanging-valley outlets of Lake Pelham above Dwight's Station and the pass at the Belchertown ponds face each other like the broken ends of a Roman aqueduct," and it is quite probable that they were once connected by a channel in the front slope of the glacier when ice south of the Holyoke Range had disappeared.

The deposits in Lake Pelham basm are particularly interesting and have been described in detail by Emerson. ${ }^{23}$ Sand is banked on the north and east slopes of this basin, well up to and above the high level of the outlet to Jabish Brook. On the south and east slopes of the basin sand is almost wholly lacking. From these high levels the sand extends downward to the till plain, which is traversed by the north-south road at 640 to 650 feet above sea level, and there spreads out, terminating in a series of lobes or ridges like a lobed delta front somewhat dissected by erosion. The till plain represents the original bottom of the basin on which the delta sand encroached but which it did not cover, as it was swept down from the uplands by tributary streams, fecl perhaps by the melting of the ice sheet. The most interesting part of this deposit is a great sinuous ridge of sand and fine gravel which thrusts its rounded end out upon the till plain as one of the lobes of the deposit. The side slope of the ridge drops 40 to 60 feet on the south and east to a narrow ravine cut by Amethyst Brook through the sand and 10 or 15 feet into the

${ }^{23}$ Emerson, B. K., Geology of old Hampshire County, Mass. : U. S. Geol. Survey Mon. 29, pp. $578-584,189 \mathrm{~s}$. 
till to the rock below. On the north and west sides the slope at its terminus drops abruptly 30 to 40 feet to a marshy till flat, and east of this flat the slope spreads out somewhat more indefinitely as the sand merges into the rest of the deposits on the north. The ridge can be traced up the slope to the northeast for about 1,100 yards, then turns to the north for about 350 to 450 yards, and becomes a bulky hill, 40 to 60 feet high. Swinging back to the northeast, nearly parallel to the road, the ridge again becomes narrow and sharp and is cut through by a small creek that drains a depression on the north. Beyond the notch the deposit merges into the slope north of the creek below the road corners, where Amethyst Brook comes down from the uplands to the northeast.

There are two interpretations of this feature. Under one it is a true esker, the deposit of a stream that flowed southwestward in a sinuous channel in the ice while yet the basin was occupied by the glacier, the sand and gravel being let down as a ridge on the lake bottom when the ice melted, and then surrounded by sand washed into the lake. Under the other interpretation the ridge is part of the lobed lake terrace or delta carved into ridge form when Amethyst Brook excavated the ravine that closely borders it on the south and east, the low marshy tract on the north never having been filled. Each interpretation has something in its favor. The material of the ridge, like that of the other lobes, is principally sand and fine gravel, and the dip of the bedding shows that the wash came from the east or northeast. No fragments of red standstone from the Connecticut Valley, to the west, were seen. This direction of wash is what would be expected if the ridge is part of the delta built out into the lake by streams from the upland on the north and east, but it is the opposite of what would be expected in a stream flowing on the glacier near its margin. When the ice occupied the basin to the exclusion of the lake its surface must have been higher on the west and southwest; otherwise when the basin was opened it would not have retained a lake up to the high level of the upper sand, but the water would have continued to flow westward and would have escaped into the Connecticut Valley. In other eskers seen by the writer in Massachusetts and elsewhere the esker-forming streams clearly flowed in or on the ice toward its margin, even when that course led them over what are now rising slopes. In the highest part of the ridge there may be some morainal deposits, for the sand here is accompanied by considerable coarse cobblestone gravel and numerous larger blocks of rock. Sand excavated in the road. west of Amherst Reservoir is used for brass molding. It is fine, clean, white, and beautifully stratified, the beds dipping southward, toward the lake outlet. 
Farther down the valley to the west a flat terrace sloping gently eastward borders the steep rocky south and east slopes of Mount Orient and apparently was once continuous southward across the portal. The dam thus formed is now deeply notched by the narrow gorge of Amethyst Brook. This terrace represents a final stage of the lake, when the water was escaping southward between the glacial front and the rock slope. Emerson states that excavations for the water mains that lead westward from the reservoir down the slope of the valley exposed $(a)$ semimorainic beds in the portal over the till where the ice front stood, $(b)$ above and east of these, westwarddipping back-set beds where the sand slumped on the melting of the ice retaining wall, and $(c)$ east of these, beautifully cross-bedded sand and gravel, whose flow and plunge structure and prevailing eastward dip show them to have been deposited by a strong current flowing eastward from the ice front into the lake basin.

As the uplands of Shutesbury and Leverett were cleared of ice temporary lakes occupied the valleys while they were blocked by the glacier on the west, and considerable deposits of sand were left. At Dudleyville a narrow terminal moraine lies across the northwest side of the basin, showing the position of the ice front when it blocked the valley. Terrace sand about Lake Wyola and at Moores Corners is the last evidence of the proximity of the ice on the upland east of the Connecticut within the Ware quadrangle. When the terrace was being formed in the lake at Moores Corners the wild and picturesque gorge known as Rattlesnake Gutter must have been occupied by a rushing mountain torrent, plunging down over the fallen rocks to the lowland on the west and eroding a narrow valley in the sand and the gravel terrace that borders Pond Brook southward to East Leverett. Emerson found deposits of the shore of a lake at the level of the col leading from Moores Corners to Rattlesnake Gutter and attributes the erosion of this ravine to the discharge of glacial waters across the col.

MARGINAL DRAINAGE OE THE CONNECTICUT VALLEY GLACTAL LOBE.

While disappearing from the uplands the ice still continued in the Connecticut Valley, projecting southward as a lobe of the glacial margin. How long this lobe persisted and how far it extended beyond the main ice front is not known. It seems probable, however, that the shrinking of the margin from the valley slope maintained such relations as afforded outlet southward between the rock slope and glacial margin to the open valley south of the ice lobe. The first evidence of the shrinking of the valley lobe within this area is the terrace of sand and gravel that borders the west slope of Per$92817^{\circ}-24-6$ 
kins Mountain, in Somers Township, Conn., over 300 feet above the lower parts of the plain on the west. The abrupt west slope of this deposit shows where the ice front stood while it held a small body of water at this level. The marginal streams resulting from the shrinkage flowed partly over rock, partly on the ice, and laid down considerable deposits of sand and gravel. On the final disappearance of the ice these deposits were left as the pitted morainal or kame terraces to which reference has already been made.

It seems improbable that there was at any one time a single continuous stream extending from north to south the whole length of the quadrangle between the ice and the rock slope. The stream in this position probably widened at the south to a marginal arm of the broad lake at the front of the lobe and received tributaries from the uplands. As the ice cleared successive valleys on the east more northerly tributaries came to the marginal stream, and the widening of its channel kept pace with the shortening of the valley lobe. Thus, the morainal terrace south of Scantic is probably to be correlated with the discharge from the lake in Hampden Valley and its tributaries, one of which, as has been shown, probably received for a time the overflow from glacial Lake Quaboag. The next stage resulted from the opening of Ellis Mills Valley and the valley of the Chicopee. Here the main contribution went to the open lake, the marginal stream that formed the terrace between Scantic and North Wilbraham being insignificant compared with the influx of water which these newly opened valleys permitted. The higher deposit of sand. and gravel bordering the slope northwest of North Wilbraham was probably laid down while the moraine southwest of Springfield Reservoir was being formed. Gravel in Granby bordering the low north and west slopes of the Facing Hills marks the next stage, in which most of the waters were reaching the lake by way of Broad and Jabish brooks and Chicopee River.

When the ice south of the Holyoke Range had largely or wholly disappeared and the lake in Connecticut Valley extended northward to Granby, the marginal stream flowed through the pass now occupied by the Belchertown ponds and formed the terrace described above (p. 85). The flow through this pass may have continued even after the ice had melted over the flat south of Dwight, the stream heading perhaps in Lake Pelham and going southward and soutleastward through the valley between the low till-corered ridge and the high slope on the east. A considerable deposit of sand and gravel extends along this course and broadens to a delta north of Dwight. Study of the railroad cuts in the sands banked against the slope southeast of Dwight convinced Emerson that the stream at one stage crossed the depression south of Dwight on the ice and flowed through the Belchertown pass. The depressions in the sand 
in the pass, in three of which lie the Belchertown ponds, show that considerable masses of ice were buried in the detritus carried by the stream. The stream, which was at first high on the slope and drained the Pelham lakes in the manner described above (p. 85), later lowered to the position north of Dwight. Deposits bordering the lower slope north of Amethyst Brook belonged to the same system.

In the valley of Adams Brook, a short distance upstream from the Franklin County line, is a narrow gravel flat bordering the stream. Crossing the rock ledges it rises and broadens gradually to the north and ends north of the pond at an altitude of 450 to 500 feet above sea level in an abrupt knolled and pitted slope where the ice stood for a time at the north end of Mount Boreas. Farther north the East Leverett cemetery stands on the lower terrace of sand and gravel, which overlies rocks at 420 feet above sea level. After the sand and gravel east of Mount Boreas were deposited the ice seems to have cleared the pass to the west and allowed the water flowing southward down Pond Brook valley to enter the lake near North Amherst before it had time to build the East Leverett terrace up to the level of the pass east of Mount Boreas.

THE CONNECTICUT VALLEY LAKES.

The deposits from whose study Emerson drew his inference concerning the conditions prevailing in the Connecticut Valley during and after the melting of the glacier are mostly outside the quadrangles examined by the present writer. For the full discussion of these phenomena reference should be made to Emerson's monograph, ${ }^{24}$ or for a briefer summary to the Holyoke folio. ${ }^{25}$ The present discussion of that part of the deposits within the Ware quadrangle is based on that of Emerson, whose conclusions are in the main accepted. The principal conclusions were that the melting of the thicker ice in the broad valley lagged behind that of the sheet extended over the uplands on the east, so that a valley lobe extended southward beyond the main glacial front, and that the relative altitudes of the land to the north and south and the conditions of outflow of the glacial waters were such that as the south front of the lobe retreated the broad valley thus cleared was flooded from side to side and the conditions for lacustrine deposition resulted. Emerson wrote:

The stream may have been at first like the body of water which flows from under one of the Greenland glaciers; then like the great river Yukon with its vast volume and lakelike expansions; and finally like the Rhone, heading in a glacier in our smaller New England Alps.

The waters occupied the basin while it was still largely encumbered with the remnants of the glacial ice and during all the time of the deposition of the

${ }^{34}$ Emerson, B. K., U. S. Geol. Survey Mon. 29, pp. 609-749, 189 S.

${ }^{25}$ Emerson, B. K., U. S. Geol. Survey Geol. Atlas, Holyoke folio (No. 50), 1 s9s. 
central clays floating ice was abundant. The occurrence of arctic plants in the upper portion of the clays is in harmony with this state of things, and many kettleholes in the high terrace on this edge are in part due to masses of ice covered deeply by the sands of unusual floods and remaining for long periods in the frozen soil. We may be reasonably sure, also, that no time elapsed between the disappearance of the ice and the full occupancy of the valley by flood waters. The frontal lobe of ice was buoyed up and flooded away in. the advancing waters.

The ponded condition of the extraglacial waters in the Connecticut Valley was probably due in part to differential depression of the land, decreasing gradually in amount from north to south, and in part to blocking of the valley farther south by morainal outwash and lacustrine deposits with which the retreating ice front left the valley partly filled. Undoubtedly there was some northward depression of the land, at least near the end of the glacial epoch, whether or not the land was so low that the waters in the Connecticut Valley constituted an estuary practically at sea level, as certain geologists have supposed.

The Holyoke Range cut off the Springfield basin and the Deerfield-Toby Range cut off the Montague basin, so that three great areas resulted when the valley in Massachusetts was finally cleared of ice. These areas were regarded by Emerson as sufficiently broad and sufficiently well separated to justify the term lakes, and he named them Springfield Lake, Hadley Lake, and Montague Lake. No part of the Montague basin lies within the Ware quadrangle. The broad lowlands extending southward from the Holyoke Range in Granby into Connecticut are a part of the Springfield basin, and the low tracts of Amherst Township north of the Holyoke Range belong to the Hadley basin.

As the ice front retreated the lake extended northward and successive tributary valleys were opened. The tributaries, as shown above, had been restrained in their natural courses by the temporary blocking of their outlets after the basins were cleared of ice, so that the waters were forced to find other outlets. In the temporary lakes thus formed considerable deposits of assorted drift had been made, so that when the natural and lower outlets were opened the rushing waters swept much detritus into the lakes occupying the main valley and distributed it far and wide over the valley bottom. The broad, flat delta plains in front of the Chicopee River outlet at North Wilbraham and of the outlet of Hampden Valley at Scantic have altitudes which are now, owing to postglacial reelevation of the land, 260 to 265 feet above the sea. It is therefore believed that the maximum flooding in Springfield Lake extended up to this horizon, the east shore lying along the west border of the morainal terrace noted above. Several till-covered sandstone tracts rise above this 
level in the valley floor, as shown on the map (Pl. VI). Surrounding these tracts is an extensive, nearly flat plain, pitted in places by shallow kettles and underlain principally by fine assorted drift washed out by the streams and in part by coarse gravel dropped from the melting ice but not built up to the flood level of the waters.

North of Ludlow the surface rises from a narrow stream terrace to a broad, flat plain underlain by stratified sand and gravel and pitted with numerous depressions, some of which contain ponds or swamps. This plain was either never filled up to the level of the plain south of Chicopee River or was subsequently worn down by meandering of the river as the flood waters subsided. Under the second alternative the buried ice blocks must have persisted until the plain emerged, otherwise the pits would have been filled by the shifting sand and gravel. In either case the pits constitute evidence of the proximity of the ice front at the time of deposition. So also the higher sand and gravel plain on which stands Ludlow Center, regarded as the highest terrace covered by the lake, is somewhat pitted by kettles. These are delta plains resulting from the combined outflow of the stream in Chicopee Valley and the melting Connecticut lobe and later somewhat dissected by Chicopee River and minor streams. To the north across the ridge, in the southern part of Granby, is a similar flat sandy plain about 260 feet above sea level at the south margin but rising gently northward to nearly 300 feet where it merges into a knolled and pitted morainal tract. This moraine or morainal terrace extends southward along the foot of the high rock slopes on the east, marking the position of the ice front at one stage. Apparently as the melting progressed the ice margin gradually swung away from the rock slope until it lay nearly east and west across the low tract west of Baggs Mountain, its waters meanwhile flowing southwest through the gap between the hills to the open lake, the plain thus being in reality a glaciofluvial outwash terrace.

The terrace heading in the pass traversed by the railroad 4 miles northwest of Belchertown, 307 feet above sea level at the ponds, declines southwestward to Forge Pond, where it merges with the broad, flat lacustrine plain. This terrace was formed when the ice front receded from the great kame terrace north and west of Belchertown to the position of the abrupt ice-contact slope north of Upper Pond and to the north slope of the Holyoke Range. The coarse 6 -inch gravel near the ponds gradually changes to 1 and 2 inch gravel east of Forge Pond and to fine sand spread out over the flat plain in Granby. It is thought by Emerson that

The floods of the northern basin continued for a long time to pass across the Belchertown notch into the southern basin after the latter was fully abandoned by the ice, although (1) the level of the sands in the Belchertown 
notch is about 40 feet above the level of the high terrace of the lake to the north; and (2) the abundant kettleholes show that the water ceased to pass through the notch before the ice had melted out from below the sands spread there.

In connection with the two ponds we may call to mind that arctic plants are found in the clays of Hadley Lake near their top. This indicates a cold climate at an even later time than the one contemplated here, which would permit the ice to remain buried almost indefinitely.

With the melting of the ice north of the Holyoke Range the flooding of the Hadley basin resulted. This probably began in Amherst Township in the angle south of Dwight, where the ice gave place to open water, so that the marginal stream, instead of sweeping its sands and gravels through the Belchertown pass as before, dropped them in the water north of Dwight, forming the delta, though the clarified water may still for some time have escaped by this outlet. Along the lower north slope of the Holyoke Range is a poorly marked terrace and sandy deposit. Similar deposits border the east side of the valley below the morainal terrace and are regarded by Emerson as representing the lake-shore terrace. North of East Street these deposits extend on both sides of the valley north and northwest to North Amherst. The inner margin of this terrace drops, in part with gentle slope and in part abruptly, to the broad lake-bottom plain. Fort River has eroded in this plain a lower alluvial flat 1,000 to 1,300 feet in maximum width, which extends from the railroads to a point about 1 mile north of East Street. Cuts in the lake terrace near East Street expose coarse cobblestone gravel, and east of the railroads numerous swells and large kettles show that here at least the deposit is part of the kame terrace, perhaps submerged on the withdrawal of the ice front, while the buried ice blocks yet remained intact. What is regarded as the highest lake level in this vicinity is now about 300 feet above the sea, as determined by shore phenomena at Amherst and by the level of deltas on both sides of the valley.

\section{SUMMARY OF THE PLEISTOCENE OR GLACIAL HISTORY.}

A brief summary of the historical phases of the Pleistocene geology of the area is presented below. Necessarily the deductions drawn from the observed phenomena are of a hypothetical nature. The broader questions involved, such as the canse of glaciation, are not touched upon in this discussion.

While the ice continued to advance the abrasion of the bedrock went on, together with the accumulation of the sheet of till by erosion, transportation, and lodgement, the formation of the drumlins, and the deposition of a part at least of the assorted drift of the deeper valleys. Of the rates of advance and the duration of the 
occupancy of this area by the ice no adequate measure is available. It is known that the period of continental glaciation as a whole was very long-many times as long as the time which has elapsed since the last great ice sheet disappeared. The glacial epoch in New England was brought to a close by changes in climatic conditions that resulted in an excess of the rate of melting of the ice over the rate of its advance, so that the glacial margin was melted slowly backward from south to north. As this proceeded the escaping waters prodnced the assorted drift formations which are still so well exposed. The abundant boulder's scattered over the surface and the looser upper part of the till were the final contributions made directly by the disintegrating ice, whose last detached remnants lingered long buried in the gravel at points where now are the smaller lake basins, ponds, and kettleholes.

An attempt has been made to trace the stages by which the retreating ice front traversed the area under discussion from south to north. As has already been indicated, no well-marked marginal moraines of any considerable extent have been observed that might stand as evidence of repeated stages of increased flow, which held the ice margin stationary for long intervals against the assaults of the forces of ablation. Only two marginal deposits have been traced across ridges intervening between the valleys; the morainal deposits in the valleys in places extend almost continuously for several miles in directions nearly normal to what must have been the general trend of the ice front. There are, however, indications-such as breaks in these deposits, scattered morainal patches, eskers merging at their termini with such deposits or with ice-contact margins of glacial sand plains or deltas, and the relations of the deposits of the extinct glacial lakes to the requisite retaining ice walls - that the ice did not disintegrate thronghout the area as a wholly stagnant mass, but that the retreat of the glacial front was effected by a series of stages, with intermittent halts and slight marginal accumulations of drift. It does not appear that, except for relatively small buried blocks, the valley ice continued as stagnant isolated masses after the uplands had been wholly denuded. The deposits are very largely such as indicate the influx of detritus-bearing waters from a neighboring glacial front of considerable extent. Isochronal lines, marking successive positions of the ice front, would therefore show a series of reentrants over the uplands alternating with salients projecting down the valleys, such as in the scheme presented on Plate VII (in pocket). Obvionsly, such correlations as are attempted can not be made without probability of considerable error, and there is even question whether they should be included in this discussion. It is desirable, however, to make such an analysis of the glacial history 
of the region as the phenomena warrant, and for this reason the outline of hypothetical stages is given below.

It should also be stated that the lines of correlation are not such as may be recognized on casual visits to various parts of the field. They are, indeed, almost wholly inferential and were deduced only after detailed mapping of the whole area and careful study of the relations of the deposits as plotted. The grouping of the phenomena observed seems to indicate 13 more or less distinct intervals of halt of the ice front, accompanied by characteristic deposition, alternating with stages of marginal retreat over tracts averaging 2 to 3 miles in width. The numbers assigned apply only to the area under discussion-that is, "stage 1 " does not represent the first position of halt after the abandonment of the outer moraine on Long Island but the first position of halt recognized by the writer north of the Massachusetts-Connecticut-Rhode Island State line. So far as known to the writer such correlations of phenomena in the region farther south have not been attempted. The most notable result of this correlation is the indication of the gradual development, during the deglaciation of the region, of a broad reentrant in the glacial front over the Worcester County plateau, while the margin lagged behind in the Connecticut Valley and over the lowlands east of Worcester County. Nothing more than a tabulation of the phenomena can be given in this place. The items are arranged in parallel columns for the Ware and Quinsigamond quadrangles in order of their occurrence from west to east along the several lines of correlation. It is not supposed that the deposits along each line of correlation were exactly contemporaneous in their formation. OnIy their general relations are intended to be indicated. To save space altitudes above sea level are given in the form " at 920 feet."

WARE QUADRANGLE.

Stage 1.

Small esker and frontal terrace 3 miles west of Mashapaug.

Esker frontal terrace and moraine at Mashapaug.

Moraine east of Leadmine Mountain, 3 miles southwest of Sturbridge.

Moraine at reservoir 3 miles southwest of Southbridge.

Moraine dam and lacustrine clays at brickyard $2 \frac{1}{2}$ miles south of Southbridge.
QUINSIGAMOND QUADRANGLE.

\section{Stage 1.}

Moraine and outwash gravels at Quinebaug.

Moraine at Webster and kame terraces about Lake Chaubunagungamaug.

Moraine at Badluck Pond.

Gravel at Tasseltop.

Moraine and eskers north of Chockalog Pond.

Moraine south of Ironstone.

Slight moraine at Millville, and gravel washed down the valley to the south.

Moraine from East Blackstone to Woonsocket, 
Stage 2.

Lacustrine or outwash gravel terrace at Wales; outlet southwest of Stafford, Conn., at 920 feet.

Ice contact and sand plain bloçking the valley at Holland outlet south at 720 feet.

Kame terrace extending thence northeast to East Brimfield.

Drift dam at Fiskdale.

Moraine south of Sturbridge.

Moraine at Westville.

Outwash gravel at Southbridge.

\section{Stage 3.}

Small lake in northwestern part of stafford Township, Conn.

Moraine in Monson Valley south of South Monson and outwash gravels extending thence south into Connecticut.

Lake beds in basins between Cedar Swamp and Hitchcock mountains.

Probably some of the gravels in the basin south and southeast of Brimfield.

Moraine dam at Little Alum Pond.

Moraine dam at Long Pond.

Ice contact and gravel terrace at south end of Cedar Pond (esker a little later).

Moraine and esker at Sturbridge.

Moraine at ponds in Charlton Township.
Stage 2 .

Moraines south of Blood, Hayden, and Pierpont ponds.

Kame terraces between oxford and Webster, ice contacts and sand plains.

Gravel of Sucker Brook.

Moraine at West Sutton.

Moraine and outwash at Manchaug.

Extensive moraine from Douglas to East Douglas.

Margin near Uxbridge and formation of upper kame terraces beside ice lobe in valley to south.

River cutting gravels and rock below Ironstone.

Branch River reversed.

Slight moraine and wash grarels near Mendon and South Milford.

Stage 3,

Moraines north and south of Slaters Reservoir.

Moraine north of Howarths.

Oxford outwash plain.

Later, moraine, kame terrace, fosse, ice contact, and outwash sand plrin at North Oxford.

French River cutting moraine to south.

Moraine south of Singletary Pond, Clarks Reservoir, and Pleasantdale Pond.

Moraine south of Whitins Pond.

Upper terrace gravels in Mumford Valley southeast to Uxbridge.

Upper gravel terrace forming in Blackstone Valley south to Uxbridge.

Blackstone south of Uxbridge eroding first or kame terrace and forming second terrace.

Retreat continues; Mumford River erodes first terrace and extends second terrace north from Uxbridge, and Blackstone River erodes second terrace, forming a third at $\mathrm{Ux}$ bridge, while depositing the upper terrace north of Goods Hill.

Moraine and kame terraces west of Miscoe Hill in West River valley. (Erosion of terraces may have been due to cutting down of the Blackstone Valley at Blackstone and 


\section{Stage 4.}

Marginal lake on slope west of Perkins Mountain.

Lake deposits in heads of valleys east and southeast of Hampden.

Moraine in valley south of South Monson, waters escaping southward.

A little later small moraine and esker in valley west of Mount Hitchcock.

Col $2 \frac{1}{2}$ miles west of Brimfield blocked by ice and gravels washed into Brimfield lake.

Moraine and outwash gravel in Taylor Brook valley.

Moraine northwest and northeast of Mount Dan.

Moraine south of Quacumquasit Pond. Moraine and outwash gravel terrace at north end of Walker Pond.

Kame gravels south of Cranberry Meadow Pond.

\section{Stage 5.}

Contraction of Connecticut Valley ice lobe.

Kame terrace in Somers Township, Conn., extending north to Scantic.

Lake in Hampden Valley with gravel terraces.

Kame terrace 2 miles southwest of Monson.

Moraine in Monson Valley and esker formed with outlet through the moraine to the south.

Ice margin extending north along the west slope of East Hill, blocking Quaboag Valley.

Moraine extending along north side of valley to West Brimfield and
Woonsocket at an increased rate, owing to greater concentration of drainage from the ice front as it retreated from Uxbridge up the three tributary valleys, and also to deposition of the load of the waters at places increasingly farther north.)

Ice contact and gravel terrace at Hopedale.

Outwash gravels and fine stratifierl sand in Charles River valley at Milford.

Stage 4.

Slight moraine near Charlton Depot. Moraine at West Auburn and Auburn.

Moraine northeast of Singletary Pond and Millbury.

Moraine at Wilkinsonville and Saundersville.

Margin at head of upper terrace at Fisherville.

Outwash forming upper terrace south to Riverdale.

Waters between Riverdale and Goods Hill eroding upper terrace and forming second terrace.

South of Goods Hill eroding second terrace and forming third terrace.

Kame terraces and moraine at West Upton.

Moraine, ice contact, fosse, and lateral and frontal terraces at Upton.

Waters eroding West River channel to south.

Small esker west of Peppercorn Hill.

Moraine and eskers east of North Pond.

Stage 5.

Moraine of South Spencer traceable east of Stiles Reservoir.

Moraine south and east of Cedar Meadow Pond.

Moraine near Stoneville, and later south of Worcester.

Esker at Hadwin Park.

Sand plain north of Stoneville.

Outwash gravels south of Quinsigamond.

Moraine, esker, and outwash gravels near Dorothy Pond.

Moraine at North Grafton.

Earlier, Goddard Pond fosse, ice contact, and sand plain. 
later forming drift dam at Blanchardville.

Glacial Lake Quaboag initiated in valley above and below Parksville, with outlet eastward through col to Brimfield Lake, at 720 feet or southward to Monson Valley along the broad shelf at 640 feet on the west slope of East Hill.

Ice contact and lake beds east of West Brimfield.

Moraine in Tufts Brook valley.

Moraines and small lake terrace 2 miles southeast of Warren.

Moraine 3 miles southeast of West Brookfield.

Kame terrace bordering slope south of Brookfield, thence southeast to Quacumquasit Pond and thence northeast to East Brookfield.

Brookfield glacial lake initiated in front of this ice lobe with outlet southward over the moraine at 700 feet, lacustrine clays deposited at Quacumquasit Pond.

\section{Stage 6.}

Contraction of Comnecticut Valley ice lobe.

Formation of kame terrace north of Scantic.

Hampden Valley opened, lake drained, terraces eroded, and kame terrace partly cut away at Scantic.

Margin crossing Wilbraham Mountains northeast of Wilbraham.

Glacial waters flowing southward through valleys leading to Hampden and depositing gravels in the heads of the valleys.

Moraine and frontal terrace $2 \frac{1}{2}$ miles west of Monson.

Quaboag Valley blocked north of Bald Peak at Palmer. Valley clear of ice and occupied by glacial Lake Quaboag from Palmer to the drift dam west of IVest Warren, with outlet southward through Monson Valley crossing morainal dam at 620 feet.

Moraines at Palmer Center, in Kings Brook valley and in Quaboag Valley above West Brimfield, with outwash terraces extending south in the valleys.
Moraine and esker soutliwest of Westboro.

Outwash gravels in Miscoe Brook valley.

Eskers and moraine at Westboro Reservoir.

Ice contact and sand plain on southwest side of Whitehall Pond, with outlet through col to south.

Moraine at south end of pond.

Later, morainal patches northeast of Spencer and west of Worcester.

Stage 6a (not entirely distinct from 6b).

Kame gravel south of Browning Pond. Kame gravel at Paxton.

Moraine north of Holden Reservoir.

Moraine and outwash gravels near Chaffin, with outlet southeast to North Pond.

Outwash gravel south from Summit Station.

Ice contact and sand plain at Worcester County farm at north end of Lake Quinsigamond.

Ice block in Quinsigamond basin and marginal kame terraces.

Gravel east of Temple Hill.

Moraine west of Westboro initiating glacial Lake Assabet, in basin to south, with outlet through col northeast of North Grafton.

Moraine southeast of Westboro, with esker and sand plain.

Kame gravel terraces at Hopkinton Reservoir.

\section{Stage $6 \mathrm{~b}$.}

Moraine 1 to 3 miles south of West Rutland.

Moraine at Jefferson. 
Moraine dam west of West Warren.

Lake terraces. south and southeast of Marks Mountain at Warren.

Kame terrace on east side of valley at Warren.

Quaboag Valley clear of ice east of West Brookfield, extending Brookfield glacial lake to this place. Outlet at first south over moraine south of Quacumquasit Pond at 700 feet; later with further melting of the ice water escaped westward down the valley, draining the lake.

Ice contact at south end of Wickaboag Pond and West Brookfield terrace formed.

Moraine and outwasli terrace in Ellis River valley (a little later).

Moraine and terrace gravel over lacustrine clay at East Brookfield.

Margin later retreating over North Brookfield hills and up Fivemile River valley and depositing kame gravels south of Brooks Pond and also in Sevenmile River valley.

\section{Stage 7.}

Contraction of Connecticut Valley ice lobe.

Outlet of glacial Lake Quaboag for a time south to Hampden by way of Big Brook valley east of Wilbraham. Mountains at 540 feet. Later opened by way of Ellis Mills Valley across the rock shoulder at North Wilbraham at 380 feet; still later shifted north to present position of the stream.

Formation of kame terrace between North Wilbraham and Wilbraham, with extension of delta plain in Connecticut Valley.

Upper terrace formed at Butlerville; lower terraces cut with lowering of the outlet.

Glacial Lake Quaboag lowered and Monson outlet abandoned. Lake reduced to a stream above IVest Brimfield.

Drift dams cut through at Blanchardville, West Brimfield, IVest Warren, Warren, and West Brookfield.

T'erraces above and below Palmer formed at 360 to 380 feet.
Marginal terrace at about 720 feet on nortleast slope of Davis Hill ; water beginning to escape between ice front and north slope of Maiden Hill.

Later, lake held in Quinapoxet Valley by ice from west of Oakdale, and valley filled up to about 600 feet by a marginal glacial gravel deposit.

Moraine east of Malden Hill, with outlet through col at Summit Station to Great Brook.

Ice contact and high gravel deposit (about 580 feet) at head of Great Brook and in col traversed by Boston \& Maine Railroad.

Ice lobe in Quinsigamond Valley, with kame terraces.

Outwash from col nortli and east of Harlow Hill.

Moraine about Bartlett Hill sontheast to Westboro.

\section{Stage 7.}

Position of ice front west of Oakdale not distinct.

Boylston stáge of glacial Lake Nashua (A) :

Muddy Brook outlet southwest of Boylston Center opened over drift and buried ice blocks at about 480 feet.

Quinapoxet River originated; erodes the valley filling and forms high delta at Oakdaie.

Boylston terraces formed bordering ice front in Nashua Valley.

Moraine south of Rocky Pond.

Northboro stage of glacial Lake Assabet :

Basin largely filled with sand and gravel as margin retreats.

Ice contacts at Northboro, Bartlett Pond, and Chauncey Pond.

Esker west of Bartlett Pond.

Outlet north of Westboro at about 300 feet, thence east through Sudbury Valley.

Ice contact and marginal gravel at south end of Reservoir No. 5 ; outlet south to Cordaville. 
Gravel terrace in lake north of Palmer Center moraine, outlet southwest through col at 480 to 500 feet.

Moraine east of Pattaquattic Hill, with lake to south.

IFames 2 to 3 miles northeast of Ware. Moraine and outwash terrace $1 \frac{1}{2}$ miles southwest of New Braintree.

Gravels northeast of New Braintree. Itoraine north of Brooks Pond.

\section{Stage 8.}

Contraction of Connecticut Valley ice lobe.

Opening of Chicopee Valley from Three Rivers west across the rock shelf at 360 feet (south of the present stream), thence to lake at North Wilbraham; slight lowering of lake level, and erosion of terrace at Palmer to 360 feet. With the shifting of the Chicopee to its present course between Three Rivers and North Wilbraham and the cutting of the rock gorge, glacial Lake Quaboag was reduced to a stream and the present flood plain was eroded tlirough the gravel terrace.

Delta sand and gravel of Chicopee River spread widely over the plain west and southwest of North Wilbraham.

Kame terrace north of North Wilbraham.

Moraine southwest of Springfield Reservoir.

Deposit of lacustrine outwash and moraine gravels in Jabish and Broad Brook valleys with the gradual northward recession of the ice front.

Kame terrace above Bondville.

Ware River valley blocked by moraine above Thorndike, holding a small lake above at 400 feet.

Terrace and esker formed by glacial stream flowing into this lake 2 miles northeast of Bondville.

Later, moraine in Swift River valley and esker $1_{\frac{1}{2}}^{\frac{1}{2}}$ miles below West IVare.

Fusse, ice contact, kame terraces, and frontal terrace in Beaver Brook valley.

Gravels in valley above Ware Center.

\section{Stage 8.}

Moraine north of West Rutland.

Moraine in valley south of Calamint Hill.

Gravels in Governor Brook valley.

Moraine across ridge between Governor Brook and Stillwater Valley.

Moraine, outwash, and esker 2 miles north of Oakdale.

Moraine and esker west of French Hill, with gravel at West Boylston deposited in the lake.

Boylston stage of glacial Lake Nashua (B) :

Morainal terrace and delta northeast of French Hill.

Esker, ice contacts, and broad sand plains east side of Wachusett Reservoir at $460-470$ feet.

Slight moraine west of Barnes Hill.

Stony Brook stage of glacial Lake Assabet (A) :

Outlet by way of Stony Brook valley and Fayville lowering to about 280 feet.

Ice contacts and gravel plains at corresponding levels.

Marginal gravels on west side of Reservoir No. 5. 
Kame terrace, fosse, ice contact, esker, and frontal terrace in Muddy Brook valley at Ware. With further melting of this valley lobe, extension of the esker northward and deposition of moraine south of Muddy Pond and kame terrace to the north.

Valley blocked at Gilbertville with waters ponded above, and in this pond gravel terrace deposited 1 mile east of the village.

Morainal deposits thence. northeastward along the valley to Furnace.

Frontal terrace on which stands Furnace schoolhouse formed a little later, blocking the valley at 660 to 670 feet. This held lake above it, which extended south up Winimusset Brook valley.

With further melting gravel terrace extended northeast up the valley.

Moraine extending along the valley from South Barre to Muddy Pond 2 miles southeast of Coldbrook. Outwash southward through the valley east of Oakham.

A little earlier, small temporary lakes in heads of Bell Brook valley with sand and gravel terraces.

\section{Stage 9a.}

Contraction of Connecticut Valley ice lobe.

Sand and gravel of Ludlow Center plain deposited in Springfield glacial lake.

Ice margin lying about the west and north slopes of Facing Hills.

Small esker and pitted gravels south of Belchertown.

Pitted gravels and kames east and southeast of Belchertown.

Slight trace of moraine north and east across the ridge to Swift River valley.

Molaine west of Quabin Hill.

Fosse, ice contact, and frontal gravel terrace 1 to 2 miles east of Enfield. Moraine 2 miles northwest of Hardwick.

Gravel in Moose Brook valley.

Moraine in valleys north of South Barre.
Stage 9.

Moraine from North Rutland to East Hubbardston.

Position of ice front west of Bartlett Hill indistinct.

Gravel in valley of East Wachusett Brook.

Moraine across ridge to Justice Brook valley. Outwash gravel at West Sterling.

Outwash gravel south from ice contact at West Waushaccum Pond.

Clinton stage of glacial Lake Nashua (A) :

Ice contact at Cunninghanı Brook fosse.

South-dike outlet opened at about 400 feet and gradually cut down to $380-385$ feet.

Erosion of higher deposits in the valley and development of 400 foot and 385-foot terraces.

Moraine north of Clamshell Pond. 
Ice contact and terrace 2 miles north of Coldbrook.

Moraine and outwash terrace 2 miles northeast of Coldbrook.

Stage $9 b$.

Melting of the ice in south part of Granby and gravels washed southwest through Stony Brook valley to Springfield glacial lake.

Moraine extending from Baggs Mountain northeast to the ice-contact slope west and northwest of Belchertown. Outlet down Broad and Jabish Brook valleys.

High lake terrace $1 \frac{1}{2}$ miles north of Belchertown.

Gravels at Packardville.

Gravel terraces in valleys of Caldwell Brook and west branch of Swift River, outlet stream cutting through moraine to the south.

Ice contact 2 miles northeast of Enfield, outwash forming terraces at Smiths and Enfield.

Ice contacts southwest and southeast of Mount Lizzie; sand plains to south with outlet by way of Beaver Brook valley.

Ice margin extending northward along the slope and blocking the valley below Pottapaug Pond; pond sccupied by the ice block about which was deposited gravel washed from the ice front north of Dana.

Moraines and lake terrace deposits 2 to 3 miles east of Dana.

Ice contact and outwash terrace southeast of Barre.

Moraine 3 miles east of Barre.

Gravel terrace above Barre Falls.

\section{Stage 10.}

Ice front at north slope of Holyoke Range and ice contact north of Belchertown ponds and rising thence northward along the slope east and north of Dwight.

Sand and gravel washed southwest through Belchertown pass to Springfield Lake in Granby.
Stony Brook stage of glacial Lake Assabet (B) :

Deposition of upper gravel near Berlin and South Berlin.

Marginal gravel terraces at about 280 feet southwest of Hudson.

Slight moraine northwest of Marlboro.

Outwash gravel north of Reservoir No. 5.
Stage 10.

Moraine and esker in Brigham Pond. Moraine in Hubbardston Township. Moraine in East Wachusett Brook and Keyes Brook valley.

High gravel terrace northeast of Princeton.

Slight moraine across ridge and valley south of East Princeton. 
Sand and gravel deposited in lakes, in basins southwest of Mount Lincoln and in Pelham. Outlet east to the head of Jabish Brook valley and later south over the ice to the Belchertown pass.

Gravels along the west branch of Swift River valley.

Reentrant from Prescott Ridge with small lakes held in upland valleys.

Ice contact northwest and northeast of Warner Pond and formation of Greenwich sand plain to south.

Ice contact at Sunk Pond and deposition of sand and gravel southward to Greenwich village. Water possibly ponded up to 500 feet by morainal dams north of West Ware and south of Mount Lizzie.

Outwash gravels at Nichewaug.

Kames 2 miles southeast of Petersham.

Moraine and kame terraces at Williamsville.

Moraine west of Hubbardston.

\section{Stage 11.}

Contraction of ice north of Holyoke Range initiating glacial Lake Hadley south of Dwight, with outlet through Belchertown pass.

Lower sand and gravel terrace of Lake Pelham; outlet south along the ice margin to Lake Hadley forming sand and gravel delta north of Dwight.

Kame terrace extended north as the ice margin lowered on the slope.

Small lakes held in upper valleys in Shutesbury by ice on the west.

Ice front in West Branch of Swift River valley at Cooleyville.

Reentrant over ridge to the east with ice lobe in Middle Branch valley in vicinity of Millington. Extensive sand plain to south.
Outwash gravel at West Sterling.

Moraine at Clinton Reservoir and esker to north; small lake in Bailey Brook valley to south, with delta and plain.

Moraine south of Pratt Junction, with outwash gravel south from Sterling Center. Potholes and waterworn grooves in surfaces of exposed rock ledge at Sterling Center.

Clinton stage of glacial Lake Nashua (B) :

Ice contact on south side of Coachlace Pond, fosse, and formation of north-dike sand plain.

Ice margin perhaps occupying the gorge southwest of Bolton Station and developing terrace and outwash gravels at "Acre" and Bolton Station, with waters flowing to West Berlin.

Ice contacts and outwash gravel near Fryville, with outlet southeast through col at South Bolton.

Moraine at Hudson and soutl to Fort Meadow Pond, with esker. Stony Brook stage of glacial Lake Assabet (C) :

Small delta sand plain west of Hudson and at north side of Fort Meadow Pond.

Moraine east of this pond.

\section{Stage 11.}

West of Nashua Valley ice margin north of Worcester-Marlboro area. Deposition of gravels in Wekepeke Valley and high sand plain north of Whittemore Hill.

Clinton stage of glacial Lake Nashua (C) :

Ice lobe in Nashua Valley south to Clinton and perhaps blocking North Nashua Valley.

South-dike outlet cut down to about 360 feet and delta sand plain formed southwest of South Lancaster.

Melting of ice lobe in Nashua Valley lowers water in Nortl Nashua Valley, initiates North Nashua River, and causes erosion of gravels and formation of 
Small lake in New Salem Township somewhat earlier held up by ice on the east.

Gravel 1 mile northwest of Petersham.

\section{Stage 12.}

Glacial Lake Hadley extended northward to Mount Boreas.

Ice contact north of Mount Boreas; sand and gravel washed southward through the valley on the east into Lake Hadley east of Amherst.

Lower lake deposits in Roaring Brook valley.

Moraine and lacustrine sand at Dudleyville.

Moraine southeast of Lake Wyola.

Later ice disappears from the nortliwestern part of the Ware quadrangle.

Small moraine at the head of Pond Brook.

Sand and gravel terrace formed at Moores Corners in a lake held up in Sawmill River valley with outlet southwestward through Rattlesnake Gutter. second terrace at about 360 feet on north side of present channel of the stream north of Ballard Hill.

Formation of the kame terraces extending from Bolton Station to Vaughn Hill on east side of the ice lobe.

Slight moraines and wash gravel in valley northeast of Bolton and Hudson.

Margin retreats to moraine north of Birch Hill and to Boon Pond; fosse, ice contact, and sand plain on the southwest.

Gleasondale stage of glacial Lake Assabet :

Outlet first through col southeast of Hudson to Fort Meadow Brook valley at $220-230$ feet. later through col at Gleasondale.

Assabet River initiated and eroding gravels in the basin.

Crest of Orchard Hill channeled and slight esker and delta formed as the ice margin lay across the hill.

\section{Stage 12.}

North half of Quinsigamond quadrangle almost entirely freed from ice.

Clinton stage of glacial Lake Nashua

(D) :

Outlet still through south-dike pass at about 360 feet.

Ice margin near Shirley and depositing moraine northwest of Harvard Station ( 1 to 3 wiles north of Quinsigamond quadrangle).

Laminated silt west and north of Still River station and northeast of Lancaster deposited in the lake.

Moraine in Boxboro Township, with outwash gravels in Assabet Brook and Heathen Meadow Brook valley,

Final stage of glacial Lake Assabet:

Glacial Lake Assabet drained by opening of outlet at Rockbottom.

Erosion of lower terraces in the Assabet basin. 
Stage 13.

Ayer stage of glacial Lake Nashua:

Outlet to northeast opened near Ayer at 250-260 feet causes rapid lowering of the lake level, extension of Nashua Kiver through the gorge to a debouchure in the northern part of Clinton, resulting in erosion of the valley filling above Clinton and also in North Nashua and Wekepeke valleys.

Deposits in the lake formed terraces between Clinton and Shirley.

Further recession of the ice front opened and lowered outlet to the north along the present course of Nashua River, drained the lake and closed the Pleistocene history of the Quinsigamond quadrangle.

\section{RECENT EPOCH.}

With the final disappearance of the ice from the several valleys the streams were reduced to proportions probably measurably like those of to-day and began excavating channels in the glacial débris. It appears that a few of the valleys were so blocked by drift that new outlets were found through cols, so that former courses were abandoned. It is not always possible to determine without test borings, however, that the readjustment had not taken place in preglacial time and that the courses taken after the disappearance of the ice liad not been adopted earlier. There is some possibility that Ellis Mills Valley was the preglacial course of Chicopee River, the accumulation of drift causing its abandonment for the course west from Three Rivers, where the stream was forced to cut about 80 feet in solid rock for three-quarters of a mile. One of the methods used by streams in cutting into rock bottoms of their channels is illustrated in Ware, where the river flows over rock ledges between the dam and the bridge. At this place several potholes 2 or 3 feet in diameter lave been excavated by the whirling of pebbles in the hollows of the rock surface. Other excellent examples of pothholes and waterworn ledges were observed in the rocky bed of Blackstone River below the dam near the State line, a short distance west of Blackstone (Pl. XXI, A, B). Excavation of the glacial-lake deposits began with the opening of channels in the upper parts of tributary valleys as ponded waters lowered with the retreat of the ice and has continued to the present time. The gradients of the streams are high, and in many places dams have been con- 


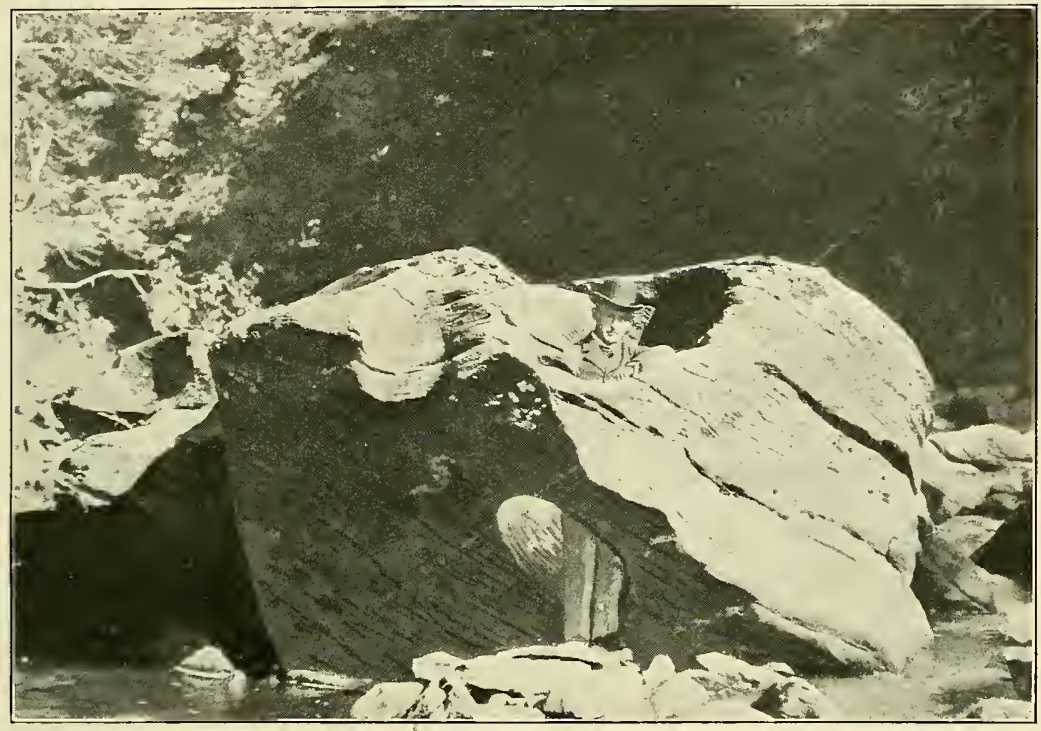

A.

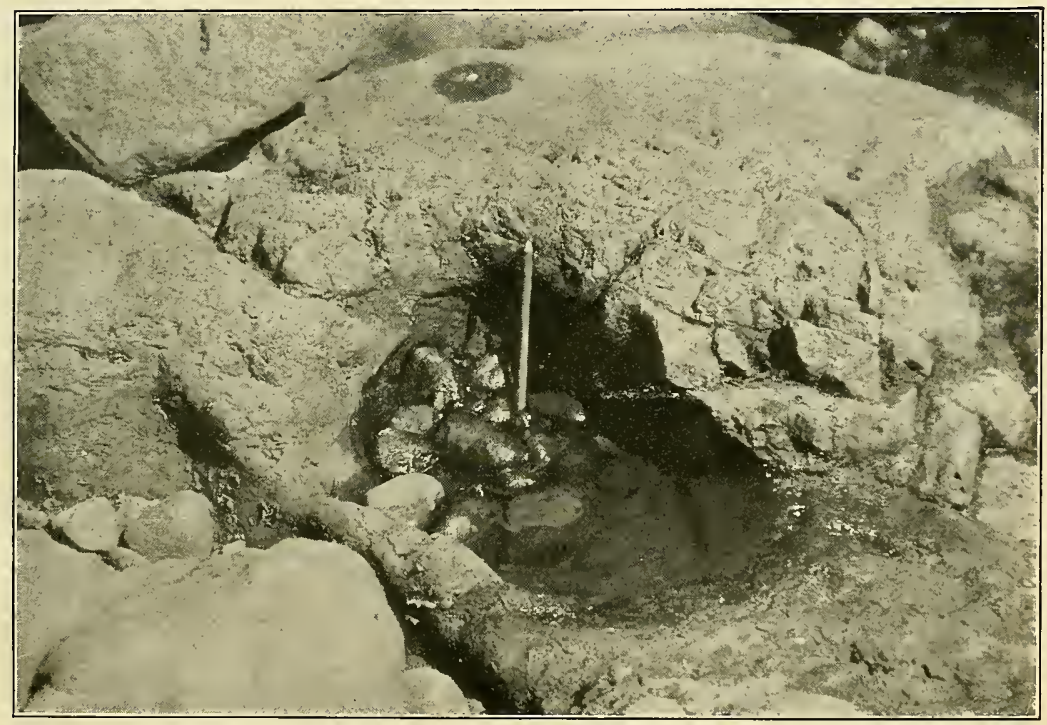

$B$.

POTHOLES IN BED OF BLACKSTONE RIVER, MASS. 


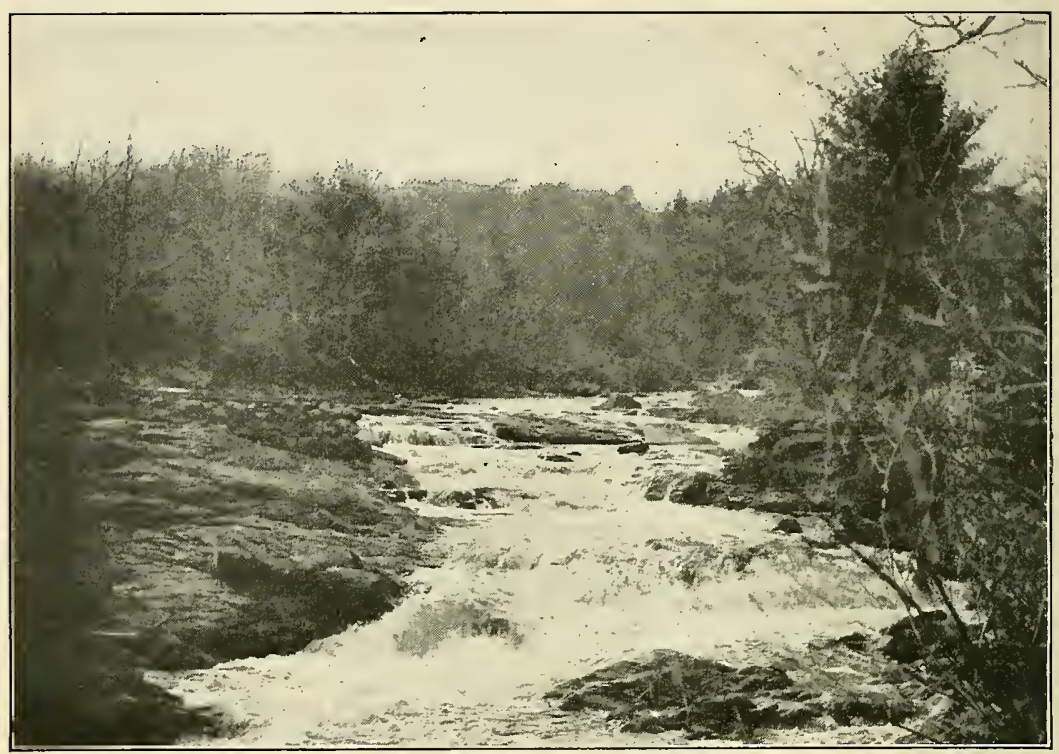

A. BARRE FALLS, MASS.

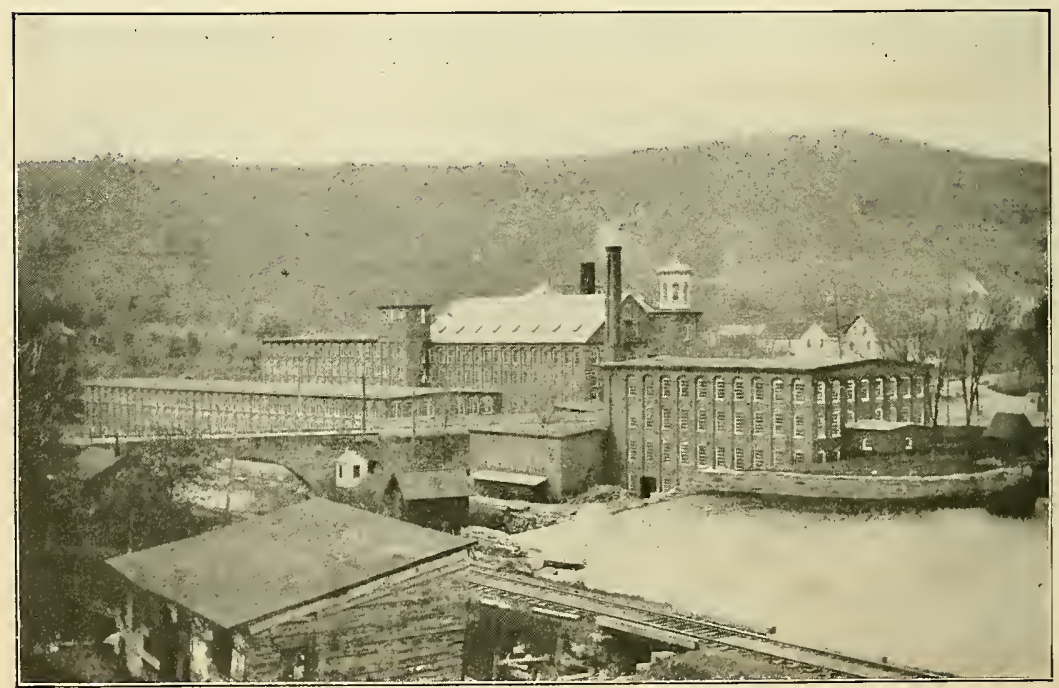

B. WOOLEN MILL, GILBERTVILLE, MASS. 
structed for reservoirs or for the development of water power (Pl. $\mathrm{XXII}, A, B)$. The present flood plains are in part due to postglacial excavation and in part to failure of the glacier to fill the valley with débris.

Monson Valley contains a great bar of drift which effectually prevented its reoccupancy by a large southward-flowing stream. So also the valley in Holland was effectually closed to southward drainage, so that the waters now cross rock ledges at East Brimfield and escape to the Quinebaug, leaving the great marsh north of Holland undrained. A similar condition prevails in Quaboag Valley above West Brookfield, the big marsh and ponds being held up by the morainal dam south of Quacumquasit Pond.

As conditions became favorable vegetation gained a foothold, a new soil was developed on the drift, forests grew, and the accumulation of peat began in the undrained areas. In such peat bogs are occasionally found the remains of animals now extinct, which roamed the land while yet the northern part of the continent was shrouded with ice and for some time after the final disappearance of the ice sheet. Franklin P. Rice, of Worcester, ${ }^{26}$ describes the finding of remains of a huge animal in a deposit of peat on the farm of William U. Maynard, near the point where the town line crosses the road between Shrewsbury and Northboro, about 2 miles northeast of Shrewsbury. Specimens of the teeth were submitted to Professors Agassiz and Allen, of the Museum of Comparative Zoology, at Cambridge, Mass., and were identified by them as teeth of Mastodon americanus [also known as Mammut americanum]. Nine teeth, four of them undeveloped, numerous pieces of bone belonging to the head, and portions of the tusks had been discovered at the time of Rice's publication. The teeth were placed in the Museum of the Worcester Natural History Society. Apparently the only Recent factor introduced into this region other than those cited above has been the incoming of white men and the consequent deforestation, tillage, and stream control.

\footnotetext{
${ }^{26}$ An account of the discovery of a mastodon's remains in Northboro, Worcester County, Mass., Worcester, 1885.
} 



